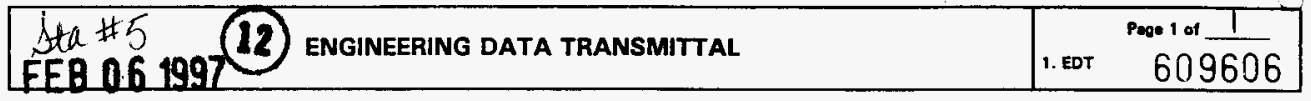

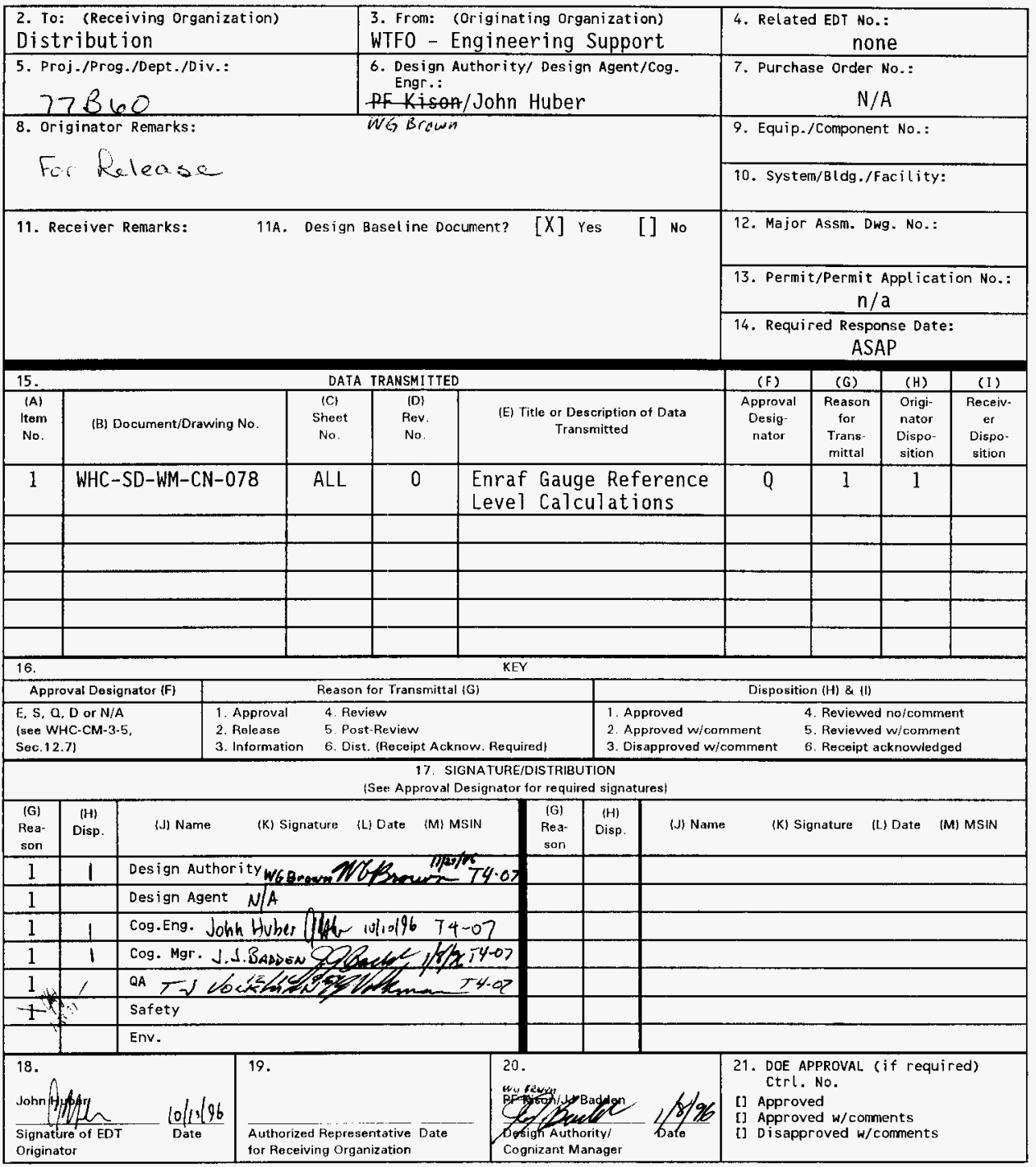

BD-7400-172-2(05/96) GEF097 


\section{ENRAF GAUGE REFERENCE LEVEL CALCULATIONS}

John Huber

Lockheed Martin Hanford Company, Richland. WA 99352

U.S. Department of Energy Contract DE-AC06-96RL13200

EDT/ECN: EDT 609606 UC: 512 and 2030

Org Code: $77 \mathrm{~B} 60$ Charge Code: N1G2J

B\&R Code: EW3120071 Total Pages: 199

Key Words: Enraf, ATG, 854. Level Gauge, LIT, DIT, Level Indicating Transmitter, Densitometer. Calculation. Analysis

Abstract: This document describes the method for calculating reference levels for Enraf Series 854 Level Detectors as installed in the tank farms. The reference level calculation for each installed level gauge is contained herein.

TRADEMARK DISCLAIMER. Reference herein to any specific commercial product, process, or service by trade nane, trademark, manufacturer, or otherwise, does not necessarity constitute or imply its endorsement, recommendation, or favoring by the United States Government or any agency thereof or its contractors or subcontractors.

Printed in the United States of America. To obtain copies of this document, contact: Document Control Services, P.0. Box 950, Mailstop H6-08, Richland WA 99352, Phone (509) 372-2420; Fax (509) 376-4989.
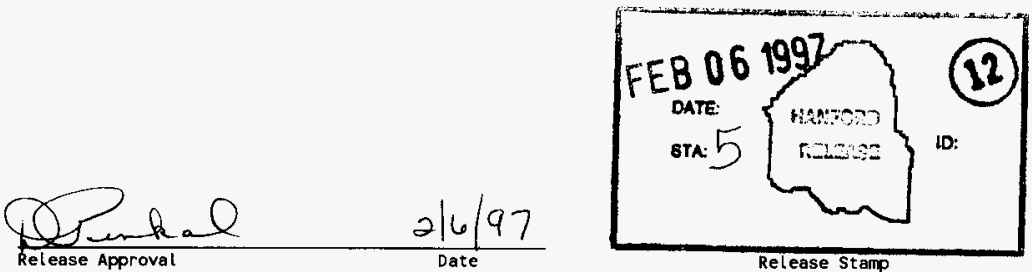

\section{Approved for Public Release}


WHC-SD-WM-CN-078

Revision $\mathrm{O}$

ENRAF GAUGE REFERENCE LEVEL CALCULATIONS

October 1996

Prepared by:

J. H. Huber, Senior Engineer

Date: $10 / 10 / 96$

West Tank Farm Operations Engineering

Reviewed by: Warren o / Date: $11 / 27 / 96$

W. G. Brown, Senior Engineer

Design Authority Engineering

Approved by:

J. J.Badden

Date:

West Tank Farm Operations Engineering

Lockheed Martin Hanford Company

P.O. Box 1970

Richland, Washington 99352 
WHC-SD-WM-CN-078

Revision 0

\section{CHECKLIST FOR INDEPENDENT REVIEW}

Document Reviewed WHC-SD-WM-CN-078 ReV.O

Author John Huber

Yes No NA

[ $]$ [ ] [ ] Problem completely defined.

[V] [ ] [ ] Necessary assumptions explicitly stated and supported.

[ $]$ [ ] [ ] Computer codes and data files documented.

[V] [ ] [ ] Data used in calculations explicitly stated in document.

[V] [ ] [ ] Data checked for consistency with original source information as applicable.

[ $\sqrt{ }[\mathrm{]}[\mathrm{]}$ Mathematical derivations checked including dimensional consistency of results.

[ ] [ ] [ $]$ Models appropriate and used within range of validity or use outside range of established validity justified.

[V] [ ] [ ] Hand calculations checked for errors.

[ ] [ ] [ 6 Code run streams correct and consistent with analysis documentation.

[r] [ ] [ ] Acceptability limits on analytical results applicable and supported. Limits checked against sources.

[ 7 [ ] [ ] Safety margins consistent with good engineering practices.

[V] [ ] [ ] Conclusions consistent with analytical results and applicable limits.

[ $6[$ [ ] [ ] Results and conclusions address all points required in the problem statement.

MANDATORY Software QA Log Number
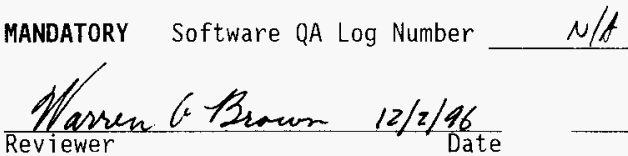
WHC-SD-WM-CN-078

Revision 0

CONTENTS

1.0 INTRODUCTION . . . . . . . . . . . . . . . . . . . . . . 1

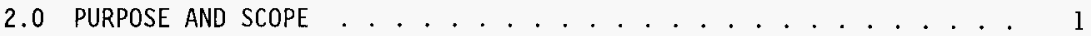

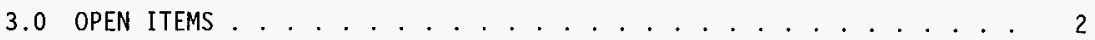

4.0 METHODS OF ANALYSIS . . . . . . . . . . . . . . . 2

5.0 INPUT DATA . . . . . . . . . . . . . . . . . . . . 4

6.0 RESULTS ......................... 7

7.0 CONCLUSIONS . . . . . . . . . . . . . . . . . . . . . . 7

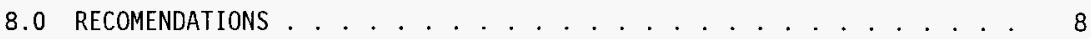

9.0 REFERENCES . . . . . . . . . . . . . . . . . . . . 8

APPENDIX $A \ldots \ldots \ldots \ldots \ldots$ 
WHC-SD-WM-CN-078

Revision 0

\section{ENRAF GAUGE REFERENCE LEVEL CALCULATIONS}

\subsection{INTRODUCTION}

Enraf Series 854 level gauges are certified by Factory Mutual (FM) for National Fire Protectional Association (NFPA 70) hazardous Class I, Division 1, Groups B, C, and D Locations. Its level measuring principle is based on the detection of variations in the weight of a displacer suspended in the process fluid. The displacer is connected to a wire wound on a precision measuring drum. A level change causes a change in the weight of the displacer which will be detected by the force transducer. Electronics within the gauge cause a servo motor to adjust the position of the displacer and compute the tank level based on the new position of the displacer drum and reference level stored within the NOVRAM (Non-Volitile Random Access Memory) of the on-board computer. The gauge displays the level in decimal inches. Accurate computation of the product level is dependent on precise calculation of the tank reference Tevel.

Listed from the tank riser upwards, the gauge installation consists of a full-port isolation ball valve, a flushing spool, a sight-glass (for viewing and accessing the displacer) and then the gauge. The tank reference level, as defined for the Enraf Series 854 gauge, is the distance from the absolute tank bottom to the top of the isolation ball valve.

\subsection{PURPOSE AND SCOPE}

\subsection{PURPOSE}

This document discribes the calculation method of the tank reference level and serves as the formal record for each reference level calculation. It is required that all future reference level calculations be included in this document via Engineering Change Notice as described in WHC-IP-0842, Volume IV, Section 3.5 .

This document will also provide verification of calculations that were previously not formally checked.

\subsection{SCOPE}

All Enrafs installed in the Tank Farms and related facilities shall have included the reference level calculation as described and required by this document. 
WHC-SD-WM-CN-078

Revision 0

\subsection{OPEN ITEMS}

None.

\subsection{METHODS OF ANALYSIS}

\subsection{THE BASIC METHOD}

As stated above, the basic method of calculating the reference level for any given method is to determine the distance from the absolute inside tank bottom to the top of the isolation ball valve. This is a simple addition and subtraction problem.

To perform this calculation, two basic parameters must be known: 1) The elevation of the bottom of the tank below the riser (or the centerline bottom of the tank for single-shell tanks which will be explained 1ater); and 2) The elevation of the tank riser flange on which the Enraf is installed.

Often, the most difficult part of the calculation is locating the most appropriate and up to date documents and/or drawings that describe these parameters. Since the information available is different in many cases, the prefered method of obtaining the data will be described first, followed by alternate methods. Terminology related to these calculations maybe obtained from Figure 1 on the following page. 


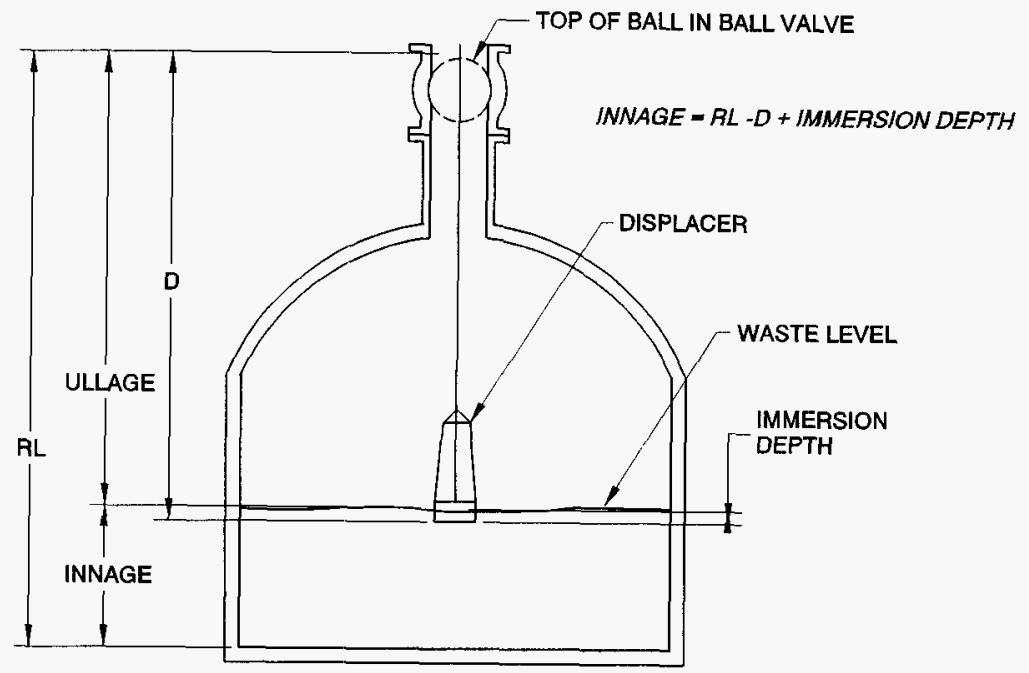

Figure 1 
WHC-SD-WM-CN-078

Revision $\mathrm{O}$

\subsection{THE METHOD}

4.2.1 Add the difference between the tank bottom and riser elevations to the length of the 4" ball valve (which is 9.0 inches standard). Then subtract the ball inset depth and add the immersion depth (if applicable). See section 5.0 INPUT DATA to determine where to obtain riser, bottom-of-tank elevation data, and how to calculate immersion depth.

The actual reference level calculations for each gauge can be found in Appendix $A$ of this document.

\subsection{INPUT DATA}

\subsection{INPUT DATA AND ASSUMPTIONS}

This section describes or 1 ists documents that contain the required input data (i.e. riser elevation, bottom elevation, etc.) Also discussed is the derivation of the immersion depth calculation.

\subsubsection{DOUBLE SHELL TANKS}

\subsubsection{Operational Test Reports}

In most cases where the document is available, the tank farm Operational Test Report (OTR) provides the most accurate data for determining tank-bottom to riser dimensions. The only exception known to date is 241-AN Tank Farm.

Known 0TRs:

AW-Farm OTP-T-990-00034 Rev A-0, "Operability Test Procedure for 241-AW Tank Farm," dated (unknown).

AN-Farm OTP-T-990-00042 Rev A-0, "Operability Test Procedure for 241-AN Tank Farm (AN-I)," dated May 16, 1980.

AP-Farm SD-WM-0TR-063 Rev 0, "Operability Test Report for 241-AP Tank Farm," dated Ju7y 22, 1986.

\subsubsection{APPLICABLE DRAWINGS}

Where the OTR is not available, or is incorrect (as it was determined for AN-Farm -- see section 5.2.1.2.1 of this document), the drawing for tank cross section shall be used to determine the bottom-of-tank elevation, and the latest revision of the Double Shell Underground Waste Storage Tanks Riser Survey (Anderson 1992) shall be used to determine the tank riser elevation. A list of Tank cross Section drawings for the double shell tanks follows. 
WHC-SD-WM-CN-078

Revision 0

TANK
241-AY
$\mathrm{H}-2-64449$
241-AP
$H-2-90534$
241-AW
$\mathrm{H}-2-70394$
241-AN-107
$\mathrm{H}-2-71160$
241-AN-101 THRU 106
241-SY -101
$H-2-79556$
241-SY-102
$\mathrm{H}-2-72213$
241-SY-103
H-2-85104

\section{2 .1 .2 .1 AN-FARM}

The OTP for AN-Farm, with regard to riser to tank-bottom dimensions, was found to be inadequate for reference level calculations. The OTP defines an acceptable dimension to be within 4 inches of the calculated dimension. Most of the field dimensions were close to 4inch tolerance. This inaccuracy is not acceptable for calculating reference levels.

To determine the adequacy of the drawings elevations, field readings were obtained at the annulus leak detectors. These readings provide a riser to annulus tank bottom dimension. The primary tank bottom elevation can then be obtained by back-calculating using drawing dimensions for wall thicknesses and insulating concrete thickness. Results indicated that the drawing dimensions were acceptable for calculating reference levels.

\subsubsection{BALL INSET DEPTH}

To determine the location of the top of the ball in the ball valve, a field measurement must be taken before the ball valve is installed. However, this has already been done for two different types of ball valves, and it is assumed that this ball inset dimension does not change for ball valves of the same part number and manufacuturer.

For a Worcestor ball valve, 4", raised face, class 150, part number 4"8246UU150, the ball inset dimension is 1.21 inch.

For a Flow-Tek ball valve, 4", raised face, class 150 , part number F15-WCB-SF-UHMW, balt inset dimension is 1.47 inch. 


\subsubsection{IMMERSION DEPTH}

The product level calculated by the gauge is based on the bottom of the displacer. The gauge subtracts the amount of wire unreeled into the tank plus the displacer length, from the known tank reference level. However, the displacer is immersed to some degree into the waste. If this immersion depth were not accounted for in the reference level calculation, the gauge would always report a product level slightly less than actual. The equation for calculating immersion depth is derived as follows.

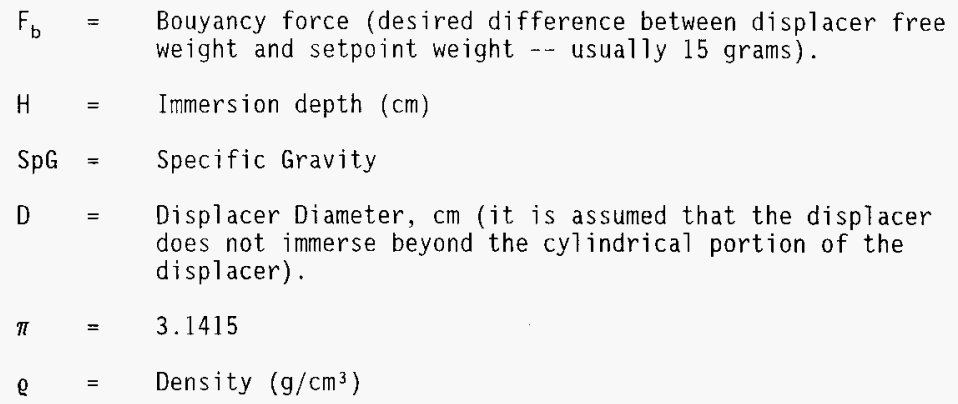

Then,

$F_{b}=$ volume displaced $x$ density of 1 iquid displaced

$F_{b}=\frac{\pi D^{2}}{4} \times-\frac{H}{4} \times$

Solving for $\mathrm{H}$,

$H=\frac{4 F_{b}}{--\frac{D^{2}}{Q}}$

But numerically, $\varrho$ is equivalent to $S p G$.

For example, the density of water is $1 \mathrm{gram} / \mathrm{cm}^{3}$, and the Specific Gravity is 1 as well. So,

$\mathrm{H}=\frac{4 \mathrm{~F}_{\mathrm{b}}}{-\frac{\pi \mathrm{D}^{2} \mathrm{SpG}}{\text { Iiquid. }}}=$ Displacer Immersion Depth, in $\mathrm{cm}$, in any given 
WHC-SD-WM-CN-078

Revision 0

It should be noted that in some cases with double-shell tanks, and in many cases with single-shell tanks, an immersion depth calculation will not be required where the waste surface is solid. The waste surface condition may be determined by reviewing historical or obtaining new intank videos/photos.

\subsubsection{SINGLE-SHELL TANKS}

5.2.2.1 The primary and most reliable source of information for determining riser and tank bottom elevations are the $\mathrm{H}-2-$ riser elevation drawings listed below.

Farm $\quad$ Drawing

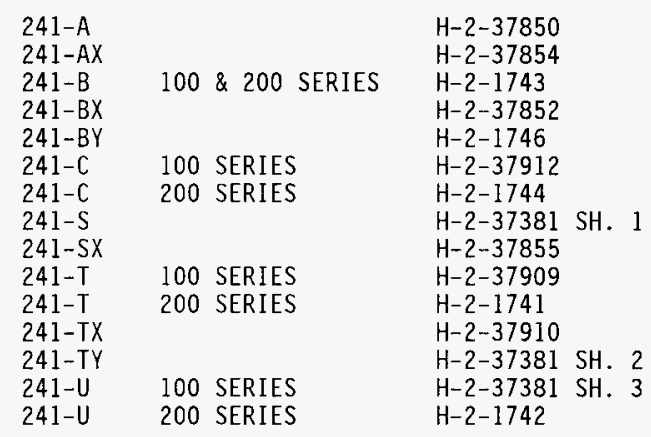

5.2.2.2 Assumptions 5.2.1.3 AND 5.2.1.4 apply to single-shell tank calculations as well as double-shells.

5.2.2.1 It should be noted that the Single-Shell Tank Riser Configuration Document (WHC-SD-WM-TI-053) has been found to contain errors with regard to both riser and tank bottom elevations. For this reason, that documet is not used for Reference Level Calculations.

\subsection{RESULTS}

The results of these reference level calculations can be found in Appendix $A$ of this document.

\subsection{CONCLUSIONS}

This document is considered to be a living document and shall be updated via ECN whenever a new reference level calculation is determined for new or existing Enraf gauges. 
WHC-SD-WM-CN-078

Revision 0

\subsection{RECOMENDATIONS}

The reference levels found in this document should be considered the official record. In the event of discrepancy this record must take precedence over all other documents.

\subsection{REFERENCES}

WHC-IP-0842, Volume IV, Section 3.6, Revision 0a, "Engineering Calculations," dated August 30, 1996

WHC-SD-RE-TI-093 Revision 3, "Double-She7l Underground Waste Storage Tanks Riser Survey," dated May 11, 1992. 
WHC-SD-WM-CN-078

Revision 0

APPENDIX A

ENRAF REFERENCE LEVEL CALCULATIONS

A-1 


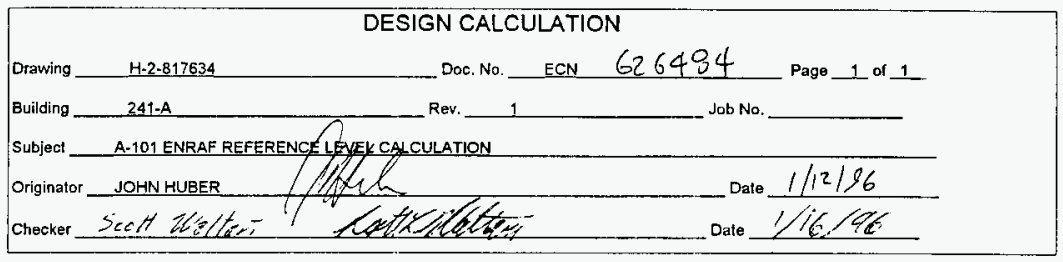

TANK NUMBER A-101

BOTTOM OF TANK TO RISER DIMENSION

DRAWING NUMBER $(\mathrm{H}-2-37850)$

RISER NUMBER

(6)

RISER ELEVATION (Ft.) 690.4500

TANK INSIDE BOTTOM ELEVATION (Ft.) - 636.7300

TANK SIDE-BOTTOM ELEVATION (Ft.) RISER TO TANK BOTTOM ELEVATION

\section{DETERMINING REFERENCE LEVEL:}

1/16 GASKET @ 50\% COMPRESSION (In.) + 0.0313 (B) PVC FLANGE (OPTIONAL) (In.) + 1.0000 (C)

$1 / 8$ GASKET @ $50 \%$ COMPRESSION (In.) + 0.0625 (D)

BALI VALVE FLANGE TO FLANGE (In.) + 9.0000 (E)

SHORT SPOOL W/GASKETS - EXST (In.) + 4.0000 (H) [Field Measured]

BALL INSET DIM (FROM TOP) (In.) - 1.2100 (F) [field measured from Ball value

IMMERSION DEPTH IN SOLIDS (In.) +

REFERENCE LEVEL ( In.) $\quad 657.5238$ 
WHC-SD-WM-CN-078

REVISION 0

THIS PAGE RESERVED FOR A-102

A-3 


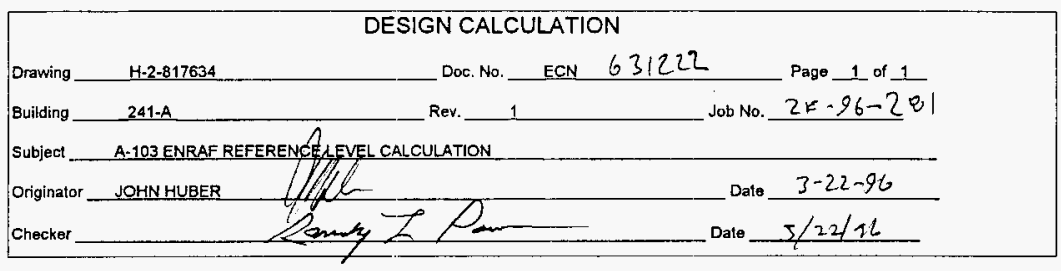

TANK NUMBER A-103

BOTTOM OF TANK TO RISER DIMENSION

DRAWING NUMBER $(\mathrm{H}-\mathrm{Z}-37850)$

RISER NUMBER (6)

RISER ELEVATION (Ft.) 688.2500

TANK CL BOTTOM ELEV. (Ft.) - 634.7300

RISER TO TANK BOTTOM ELEV. (Ft:) 53.5200

(A)

\section{DETERMINING REFERENCE LEVEL:}

$1 / 16$ GASKET @ 50\% COMPRESSION (In.) +0.0313 (B)

PVC FLANGE (OPTIONAL) (In.) + 1.0000 (C)

$1 / 8$ GASKET @ 50\% COMPRESSION (In.) + 0.0625 (D)

BALL VALVE FLANGE TO FLANGE (In.) + 9.0000 (E)

SHORT SPOOL W/GASKETS - EXST (In.) + 4.0000 (H)

BALL INSET DIM (EROM TOP) (In.) - 1.4700 (F) FIELDMEASURED FROMBALL VALVE

IMMERSION DEPTH IN SOLIDS (In.) + 0.0000 (G)

PART NUMBER H-2-817634-48

\section{REFERENCE LEVEL ( $\mathrm{Fn}$. $\quad 654.8638$}

$(\mathrm{A}+\mathrm{B}+\mathrm{C}+\mathrm{D}+\mathrm{E}+\mathrm{H}-\mathrm{F}+\mathrm{Gt})$ 


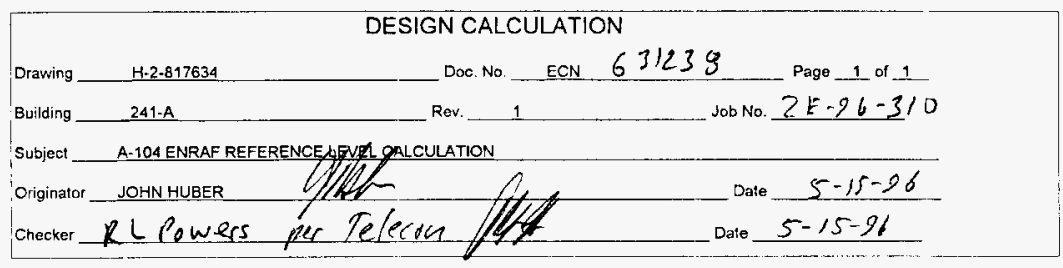

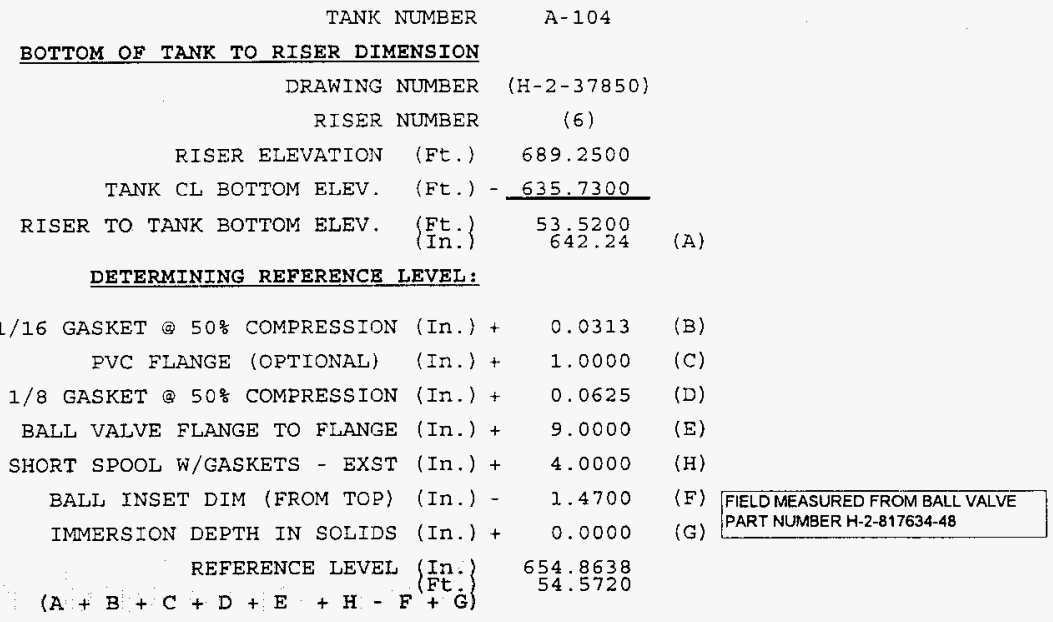


THIS PAGE RESERVED FOR A-105 


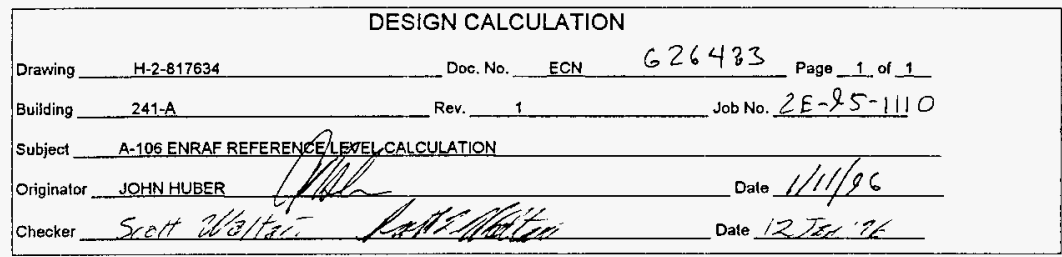

TANK NUMBER A-106

BOTTOM OF TANK TO RISER DIMENSION

DRAWING NUMBER (H-2-37850)

RISER NUMBER (6)

RISER ELEVATION (Et.) 687.1100

TANK CL BOTTOM ELEV. (Et.) - 633.7300

RISER TO TANK BOTTOM ELEV (Ft (In) $\begin{aligned} & 53.3800 \\ & 640.56\end{aligned}$

DETERMINING RERERENCE LEVEL;

$1 / 16$ GASKET @ 50\% COMPRESSION (In.) + 0.0313 (B)

PVC FLANGE (OPTIONAL) (In.) + 1.0000 (C)

$1 / 8$ GASKET @ $50 \%$ COMPRESSION (In.) + 0.0625 (D)

BALL VALVE FLANGE TO FIAANGE (In.) + 9.0000 (E)

SHORT SPOOL W/GASKETS - EXST (In.) +

4.0000 (H) [Field Mensured]

BALL INSET DIM (FROM TOF) (In.) -

1.4700

(F) FIELD MEASURED FROM BALL VALVE

IMMERSION DEPTH IN SOLIDS (In.) +

0.0000

(G) PART NUMBER H-2-817634-48

653.1838

54.4320 


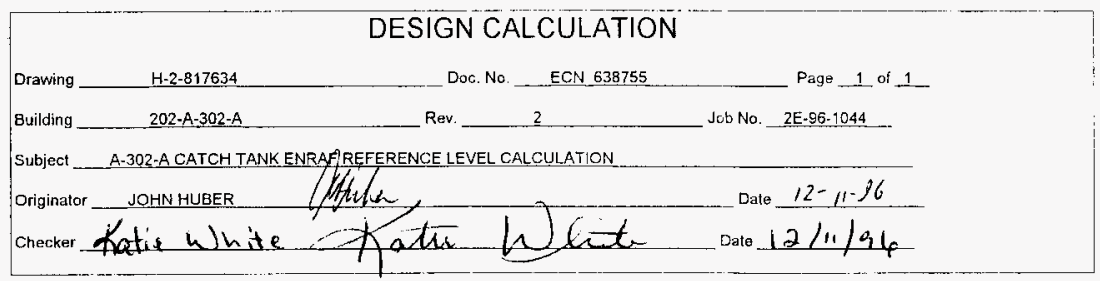

TANK NUMBER

A-302-A

\section{BOTTOM OF TANK TO RISER DIMENSION}

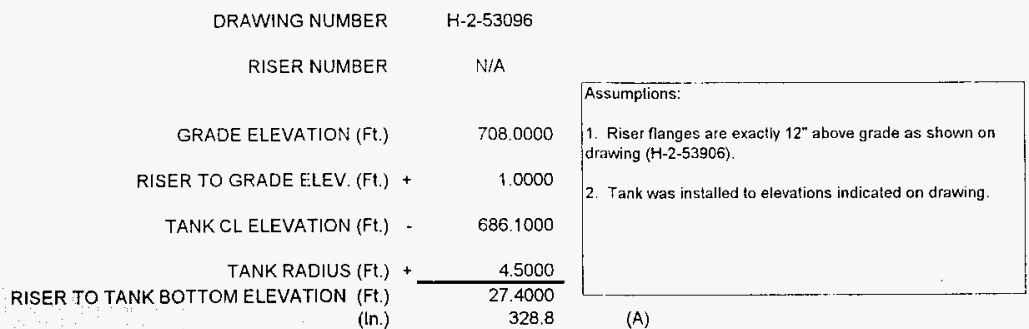

DETERMINING REFERENCE LEVEL:

$\begin{array}{rrc}\text { 1/16 GASKET @ 50\% COMPRESSION (In.) + } & 0.0313 & \text { (B) } \\ \text { 6" TO 4" ADAPTER SPOOL (In.) + } & 6.0000 & \text { (C) } \\ \text { 1/16 GASKET @ 50\% COMPRESSION (In.) + } & 0.0313 & \text { (D) } \\ \text { BALL VALVE FLANGE TO FLANGE (In.) + } & 9.0000 & \text { (E) } \\ \text { BALL INSET DIM (FROM TOF) (ln.) - } & 1.4700 & \text { (F) } \\ \text { IMMERSION DEPTH (In.) + } & 0.2775 & \text { (G) } \\ \text { REFERENCE LEVEL (ln.) } & 342.6700 & \\ (\mathrm{Ft}) & 28.5558 & \end{array}$

\section{*IMMERSION DEPTH CALCULATION}

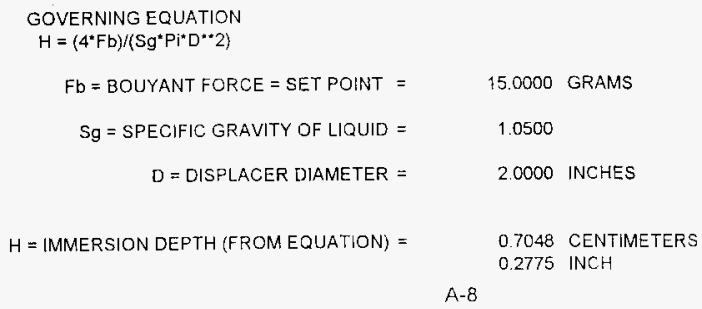




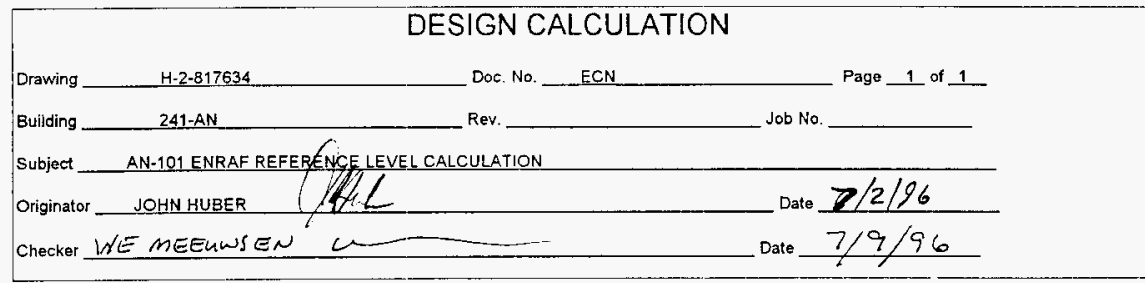

TANK NUMBER

AN -101

BOTTOM OF TANK TO RISER DIMENSION

DRAWING NUMBER ( $\mathrm{H}-2-71975)$

RISER NUMBER (2A)

RISER ELEVATION (Ft.) 668.7500

TOP OF CONC. FOUNDATION (Ft.) 612.3300

ANN. BOTTOM PL. THICKNESS (Ft.) 0.0313

INSUL. CONC. THICKNESS (Ft.) 0.6667

PRI. BOT"TOM PL. THICKNESS (Ft.) 0.0417

RISER TO TANK BOTTOM ELEVATION (FE-) 55.6803

DETERMINING REFERENCE LEVEL:

1/16 GASKET @ 50\% COMPRESSION (In.) +

0.0313 (B)

PVC FLANGE (OPTIONAL) (In.) +

1.0000

(C)

$1 / 8$ GASKET @ 50\% COMPRESSION (In.) +

0.0625

BALL VALVE FLANGE TO FLANGE (In.) +

9.0000

(E)

BALL INSET DIM (FROM TOP) (In.) -

1.4700

(F)

IMMERSION DEFTH AT $1.05 \mathrm{Sp}$. G. (In.) +

0.2775

(G)

REFERENCE LEVEL ( $\mathrm{In}$. $\begin{array}{r}677.0648 \\ 56.4221\end{array}$

$$
\begin{array}{r}
(A+B+C+D+E-F+G) \\
H=(4 * \mathrm{Fb}) /\left(S g^{*} F^{*} D^{\star} \star 2\right)
\end{array}
$$

$\mathrm{Fb}=$ BOUYANT FORCE = SET POINT =

15.0000 GRAMS

$S g=$ SPECIFIC GRAVITY OF LIQUID =

1.0500

$\mathrm{D}=$ DISPLACER DIAMETER =

2.0000 INCHES

$\mathrm{H}=$ IMMERSION DEPTH (EROM EQUATION) =

0.7048 CENTIMETERS 


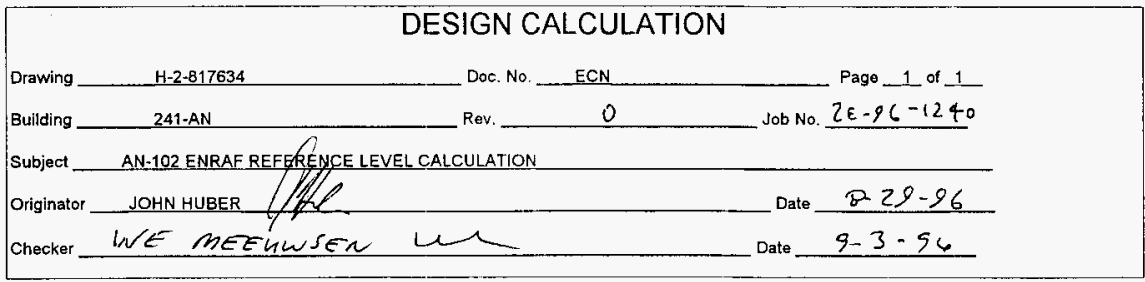

TANK NUMBER AN-102

BOTTOM OF TANK TO RISER DIMENSION

DRAWING NUMBER (H-2-71975)

RISER NUMBER (2A)

RISER ELEVATION (Ft.) 668.7500

TOP OF CONC. FOUNDATION (Ft.) 612.3300

ANN. BOTTOM PL. THICKNESS (Ft.) 0.0313

INSUL. CONC. THICKNESS (Ft.) 0.6667

PRI. BOTTOM PL. THICKNESS (Ft.) 0.0417

RISER TO TANK BOTTOM ELEVATION $\left\{\begin{array}{l}\text { Ft. } \\ \text { In }\end{array}\right) \quad \begin{array}{r}55.6803 \\ 668.1636\end{array}$

DETERMINING REFERENCE LEVEL:

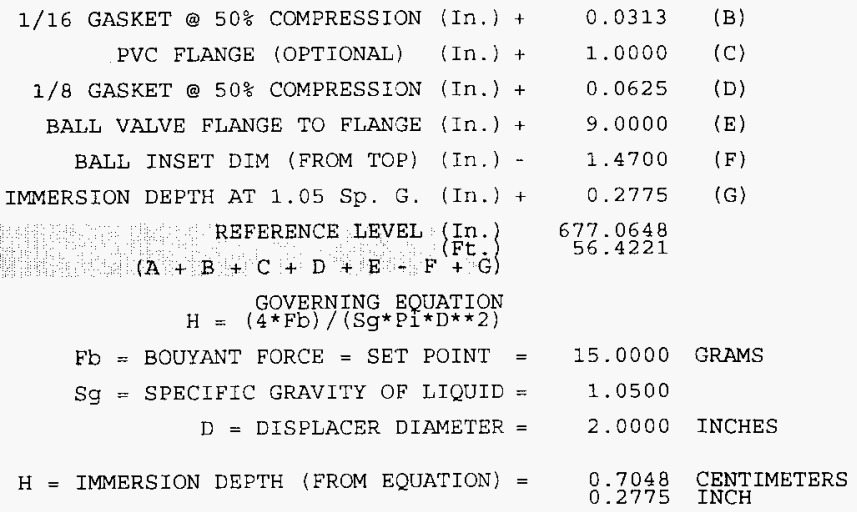



(1) Drawing $1+-2-917634$
(2) Doc. No.
(4) Building
$241-A N$
(5) Rev.
(3) Page
of 1
(7) Subject AN-1 03 Encal Ret. Level Calc.
(8) Originator Vohn ltuber Sthulu
(6) Job No.
(9) Checker mecher es gornton
Date $3 / 20 / 95$
Date $3 / 21 / 85$

(10)

TANK NUMBER

BOTTOM OF TANK TO RISER DIMENSION

DRAWING NUMBER

RISER NUMBER

RISER ELEVATION (Ft.)

TOP OF CONC. FOUNDATION (Ft.)

ANN. BOTTOM PL. THICKNESS (Ft.)

INSUL, CONC. THICKNESS (Ft.)

PRI. BOTTOM PL. THICKNESS (Ft.)

RTSER TO TANK BOTMON ELEVATION, IFt.)

(n.,.)
AN-103

(H-2-71975)

668.7500

612.3300

0.0313

0.6667

0.0417

55.6803

668.1636

\section{PARAMETERS}

$T T=701.64735$

$\mathrm{UR}=701.64735$

$\mathrm{MH}=696.04735$

$\mathrm{HH}=689.04735$

$\mathrm{HA}=683.04735$

$\mathrm{RL}=677.04735$

$\mathrm{AN}=\mathrm{N} / \mathrm{A}$

$\mathrm{AM}=\mathrm{N} / \mathrm{A}$

$T I=$.AN 103

$M I=6.0000$

$L A=12.0000$

$\mathrm{LI}=1.0000$

$\mathrm{WT}=\mathrm{EDE}$

\section{DETERMINING REFERENCE LEVEL:}

1/16 GASKET a $50 \%$ COMPRESSION (In.) +

0.0313

(B)

PVC FLANGE (OPTIONAL) (In.) +

1.0000

(C)

$1 / 8$ GASKET @ 508 COMPRESSION (In.) +

0.0625

(D)

BaLL VALVE FLANGE TO FLANGE (In.) +

9.0000

(E)

BALI INSET DIM (FROM TOP) (In.) -

1.2100

(F)

IMMERSION DEPTH IN SOLIDS (In.) +

REFERBNEE IEVEL. (1.).

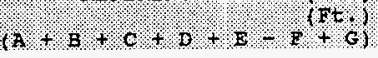

677.0473

56.4206 

(1) Drawing $17-2-817634$
(2) Doc. No
$-$
(3) Page 1 of 1
(4) Building
$241-A N$
(5) Rev.
0
(6) Job No.
(7) Subject $A N-104$ EnraffRet. Level Calc.

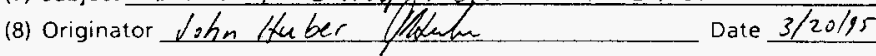
(9) Checker meace st fountom Date $3 / 2 / 95$

(10)

TANK NUMBER

BOTTOM OF TANK TO RISER DIMENSION

DRAWING NUMBER

RISER NUMBER

RISER ELEVATION (Ft,)

TOP OF CONC. FOUNDATION (Ft.)

ANN. BOTTOM PL. THICKNESS (Ft.)

INSUL. CONC. THICKNESS (Ft.)

PRI. BOTTOM PL. THICKNESS (Ft.)

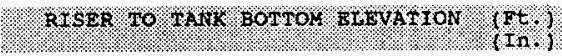

DETERMINING REFERENCE LEVEL:
AN-104

(H-2-71975)

(2A)

668.7500

612.3300

0.0313

0.6667

0.0417
PARAMETERS

$\mathrm{TT}=701.64735$

$\mathrm{UR}=701.64735$

$\mathrm{MH}=696.04735$

$\mathrm{HH}=689.04735$

$\mathrm{HA}=683.04735$

$R L=677.04735$

$\mathrm{AN}=\mathrm{N} / \mathrm{A}$

$A M=N / A$

$\mathrm{TI}=. \mathrm{AN} 104$

ML $=6.0000$

$L A=12.0000$

$L \mathrm{~L}=1.0000$

$\mathrm{WT}=\mathrm{EDE}$
55.6803
668.1636

(A)

1/16 GASKET \& $50 \%$ COMPRESSION (In.) + PVC FLANGE (OPTIONAL) (In,) + $1 / 8$ GASKET @ $50 \%$ COMPRESSION (In.) + BALL VALVE FLANGE TO FLANGE (In.) + BALI INSET DIM (FROM TOP) (In.) IMMERSION DEPTH IN SOLIDS (In.) + (1)
(B)

0.0313

1.0000

9.0000 (E)

1.2100

(F)

0 

(1) Drawing
$1+-2-317634$
(2) Doc. No
(3) Page
1 of 1
(4) Building
(5) Rev.
0
(6) Job No.
(7) Subject AN-105 Enraf Ret. level Calc.
(8) Originator John luber ffowh
(9) Checke mickul ig o lansw
Date
Date

AN-105

TANK NUMBER

BOTTOM OF TANK TO RISER DIMENSION

DRAWING NUMBER

RISER NUMBER

RISER ELEVATION (Ft.)

TOP OF CONC. FOUNDATION (Ft.)

ANN. BOTTOM PL. THICKNESS (Ft.)

INSUI. CONC. THICKNESS (Ft.)

PRI. BOTTOM PL. THICKNESS (Ft,)

RTSER TO TAMA BOTTOY ELEVATION

at.

(In.)
(H-2-71975)

(2A)

668.7500

612.3300

0.0313

0.6667

0.0417
55.6803

668.1636
PARAMETERS

$T T=701.64735$

$\mathrm{UR}=701.64735$

$\mathrm{MH}=696.04735$

$\mathrm{HH}=689.04735$

$\mathrm{HA}=683.04735$

$R L=677.04735$

$\mathrm{AN}=\mathrm{N} / \mathrm{A}$

$A M=N / A$

$T I=$.AN105

ML $=1.00006 .00$

$\mathrm{LA}=12.0000$

$L L=6.0000-1.00$

$\mathrm{WT}=\mathrm{EDE}$

DETERMINING REFERENCE LEVEL:

$1 / 16$ GASKET a 508 COMPRESSION (In.) + 0.0313

(B)

PVC FLANGE (OPTIONAL) (In.) + 1.0000 (C)

$1 / 8$ GASKET @ 508 COMPRESSION (In.) +

0.0625

(D)

BALL VALVE FLANGE TO FLANGE (In.) +

9.0000

(E)

BALL INSET DIM (FROM TOP) (In,) -

1,2100

(F)

IMMERSION DEPTH IN SOLIDS (In.) +

0

(G)

677.0473

56.4206 


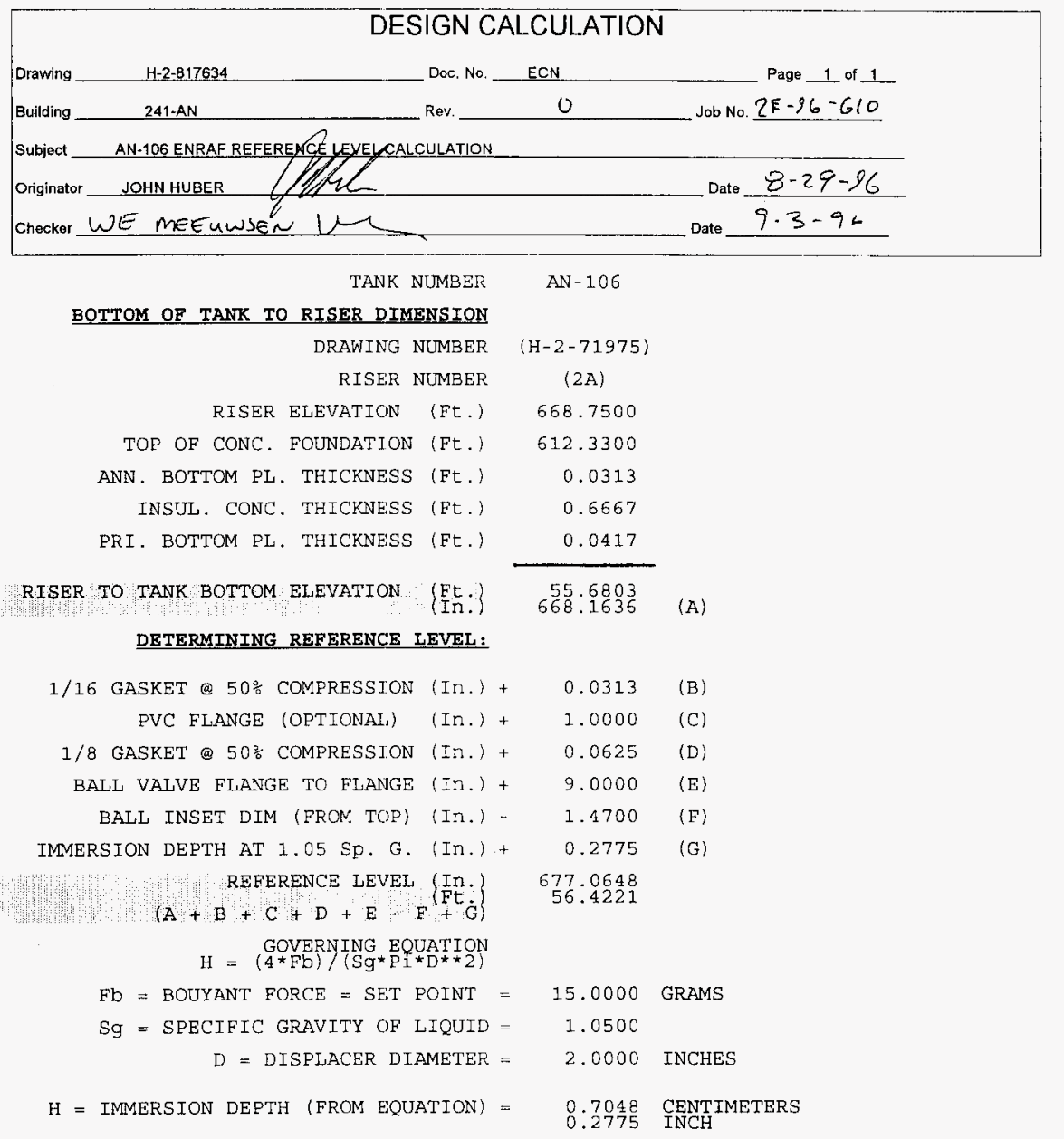




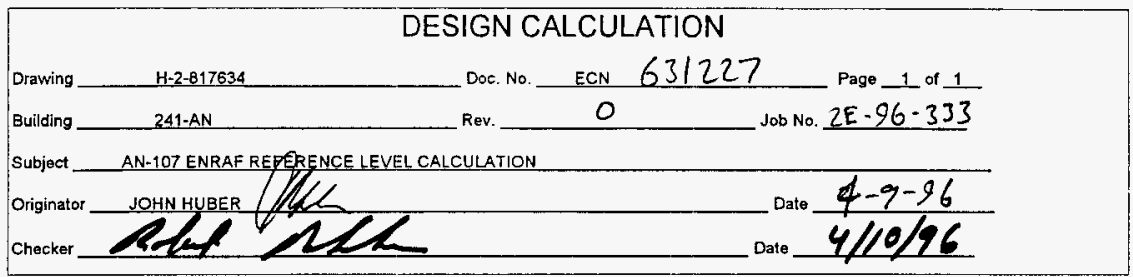

TANK NUMBER AN-107

BOTTOM OF TANK TO RISER DIMENSION DRAWING NUMBER (H-2-71160)

RISER NUMBER (2A)

RISER ELEVATION (FE.) 668.7500

TOP OF CONC. FOUNDATION (Ft.) 612.0000

ANN. BOTTOM PL. THICKNESS (Ft.) 0.0313

INSUL. CONC. THICKNESS (Ft.) 0.6667

PRI. BOTTOM PL. THICKNESS (Ft.)

RISER TO TANK BOTTOM ELEVATION \{Et. $\begin{array}{r}56.0103 \\ \text { In. }\end{array}$

DETERMINING REPERENCE LEVEL:

(A)

$1 / 16$ GASKET @ 50\% COMPRESSION (In.) + 0.0313

PVC FLANGE (OPTIONAL) (In.) + 1.0000

1/8 GASKET @ 50\% COMPRESSION (In.) + 0.0625

BALI VALVE FLANGE TO FLANGE (In.) + 9.0000

BALL INSET DIM (FROM TOP) (In.) - 1.4700

IMMERSION DEPTH AT $1.05 \mathrm{Sp} . \mathrm{G}$. (In.) + 0.2775

$\begin{array}{lll}\text { REFERENCE LEVEL (In.) } & 681.0248 & (\mathrm{In}) \\ 56.7521 & \text { (G) }\end{array}$

$(\mathrm{A}+\mathrm{B}+\mathrm{C}+\mathrm{D}+\mathrm{E}-\mathrm{F}+\mathrm{G})$

$\mathrm{H}=(4 \star \mathrm{Fb}) /\left(\mathrm{Sg} \mathrm{Q}^{\star} \mathrm{D} i \mathrm{D}^{\star \star} \mathrm{2}\right)$

$\mathrm{Fb}=$ BOUYANT FORCE $=$ SET POINT $=$

15.0000 GRAMS

$\mathrm{Sg}=$ SPECIFIC GRAVITY OF LIQUID =

1.0500

$D=$ DISPLACER DIAMETER =

2.0000 INCHES

$\mathrm{H}=$ IMMERSION DEPTH (FROM EQUATION) $=0.7048$ CENTIMETERS 
WHC-SD-WM-CN-078

REVISION 0

THIS PAGE RESERVED FOR AP-101

A- 16 
THIS PAGE RESERVED FOR AP-102 
WHC-SD-WM-CN-078

REVISION 0

THIS PAGE RESERVED FOR AP-103 
THIS PAGE RESERVED FOR AP-104 
THIS PAGE RESERVED FOR AP-105 
THIS PAGE RESERVED FOR AP-106 
WHC-SD-WM-CN-078

REVISION 0

THIS PAGE RESERVED FOR AP-107 
WHC-SD-WM-CN-078

REVISION 0

THIS PAGE RESERVED FOR AP-108 


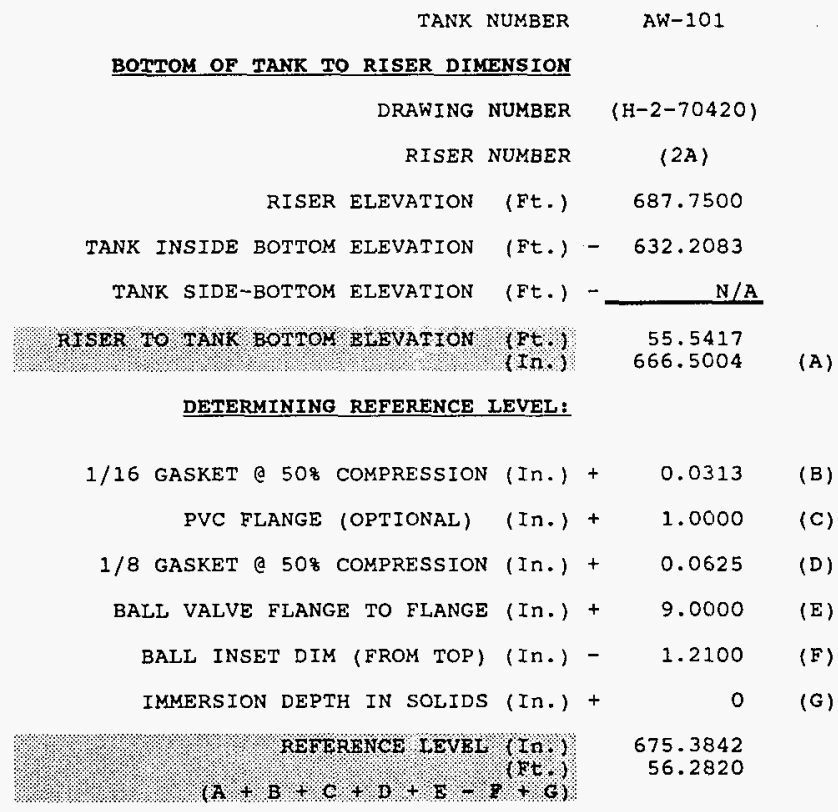




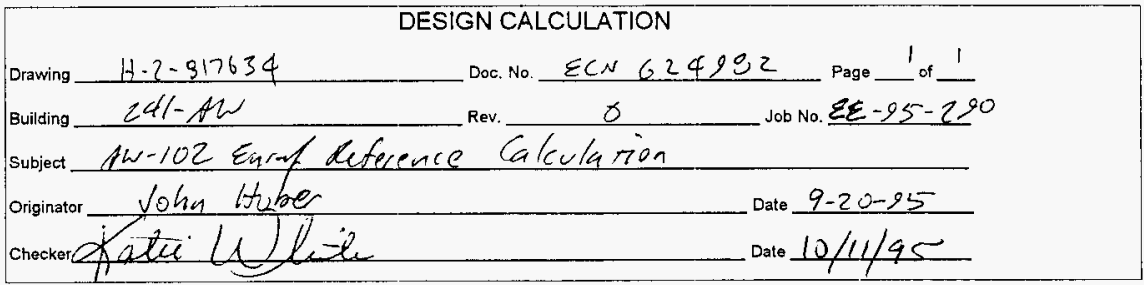

TANK NUMBER AW-102

BOTTOM OF TANK TO RISER

DRAWING NUMBER $(\mathrm{H}-2-70420)$

RISER NUMBER (16C)

MEASURED DEPTH FROM OTP

RISER TO TANK BOTTOM DEMENSION

(In.)

54.125

OTP-T-990-00034

54.1250

(A)

DETERMINING REFERENCE LEVEL:

$1 / 16$ GASKET @ 50\% COMPRESSION +

0.0313

(B)

PVC FLANGE (OPTIONAL) (In.) +

0.0000

(C)

EXTENSION SPOOL PIECE (In.) + 16.0000

(H) H-2-817634 ASSY 63

$1 / 16$ GASKET @ $50 \%$ COMPRESSLON +

0.0313

(D)

BALI VAIVE FLANGE TO FLANGE +

9.0000

(E) FIELD MEASURED

BAIL INSET DIM (FROM TOP) (In.) -

1. 4700

(F) FIELD MEASURED

IMMERSION DEPTH AT $1.05 \mathrm{SP} . \mathrm{G} .+$

0.2775

(G)

$(\mathrm{A}+\mathrm{B}+\mathrm{C}+\mathrm{H}+\mathrm{D}+\mathrm{E}-\mathrm{F}+\mathrm{G})$

673.3700

56.1142

\section{* IMMERSION DEPTH CALCULATION}

GOVERNING EQUATION

$\mathrm{H}=(4 * \mathrm{Fb}) /(\mathrm{Sg} \star \mathrm{Pi} * \mathrm{D} * \star 2)$

$\mathrm{Fb}=$ BOUYANT FORCE $=$ SET POIINT $=$

15.0000 GRAMS

$S g=$ SPECIFIC GRAVITY OF LIQUID =

1.0500

$D=$ DISPLACER DIAMETER =

2.0000 INCHES

IMMERSION DEPTH (FROM EQUATION) =

$\begin{array}{ll}0.7048 & \text { CENTIMETERS } \\ 0.2775 & \text { INCH }\end{array}$ 


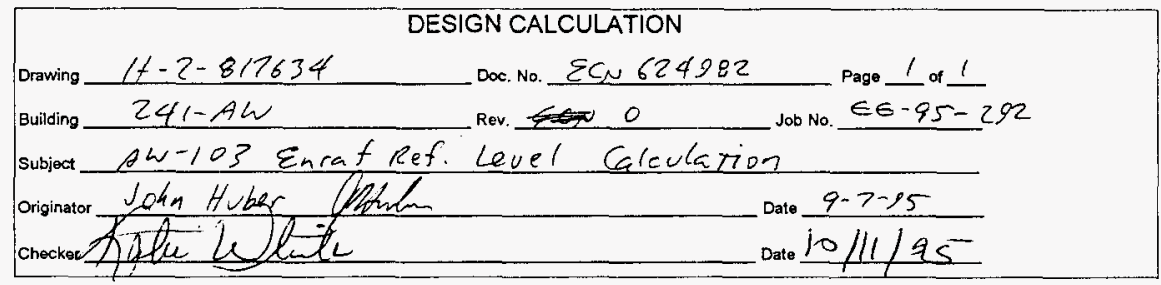

\begin{tabular}{rc} 
TANK NUMBER & AW-103 \\
BOTTOM OF TANK TO RISER & \\
DRAWING NUMBER & $(\mathrm{H}-2-70420)$ \\
RISER NUMBER & $(2 \mathrm{~A})$ \\
MEASURED DEPTH FROM OTP & 55.578 \\
\hline TO TANK BOTTOM ELEVATION & 55.5780 \\
& 66.936
\end{tabular}

RISER TO TANK BOTTOM ELEVATION

DETERMINING REFERENCE LEVEL:

1/16 GASKET \& 508 COMPRESSION +

0.0313

(B)

PVC FLANGE (OPTIONAL) (In.) +

1.0000

(C)

$1 / 8$ GASKET \& $50 \%$ COMPRESSION +

0.0625

BALL VALVE FLANGE TO FLANGE +

9.0000

(E) FIELD MEASURED

BALI INSET DIM (FROM TOP) (In.) -

1.4700

(F) FIELD MEASURED

IMMERSION DEPTH AT $1.05 \mathrm{sp.} \mathrm{G.+}$

0.2775

(G)

OTP-T-990-00034

675.8372

W $\mathrm{A}+\mathrm{B}+\mathrm{C}+\mathrm{D}-\mathrm{z}-\mathrm{r}\} \mathrm{Gt}\}$

56.3198

\section{¿IMMERSION DEPTH CALCULATION}

GOVERNING EQUATION

$\mathrm{H}=(4 \star \mathrm{Fb}) /(\mathrm{Sg} \star \mathrm{P} i \star D \star 2)$

$\mathrm{Fb}=$ BOUYANT FORCE $=$ SET POINT $=15.0000$ GRAMS

$\mathrm{Sg}=$ SPECIFIC GRAVITY OF LIQUID =

1.0500

$$
D=\text { DISPLACER DIAMETER = }
$$

2.0000 INCHES

IMMERSION DEPTH (FROM EQUATION) =

$\begin{array}{ll}0.7048 & \text { CENTIMETERS } \\ 0.2775 \text { INCH } & \end{array}$ 


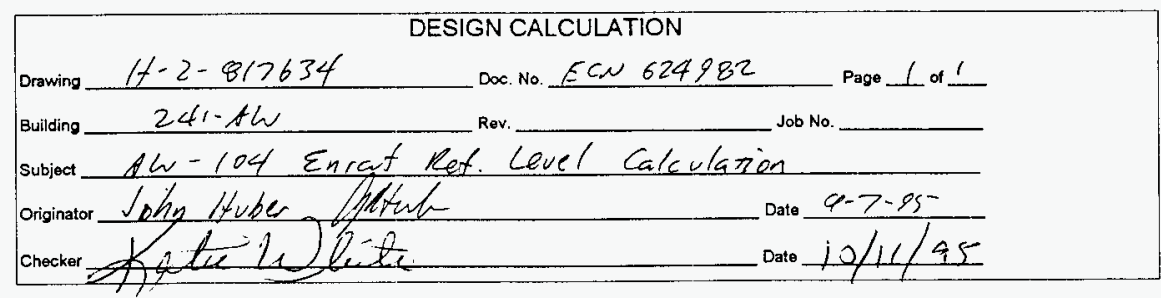

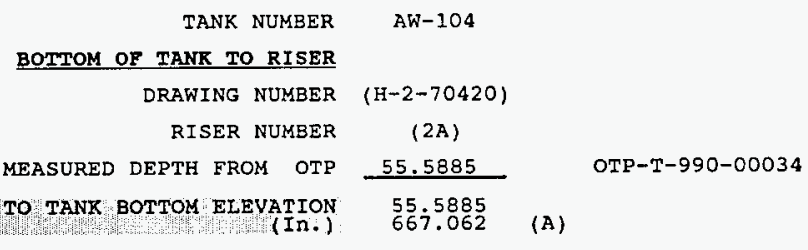

DETERMINING REFERENCE LEVEL:

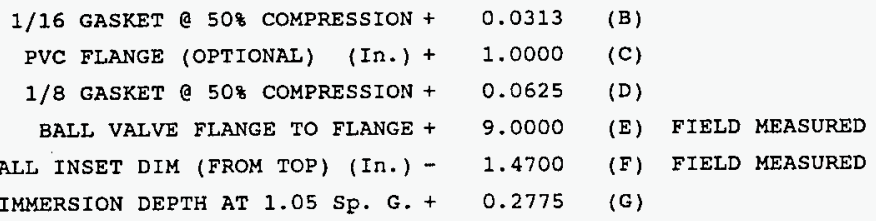

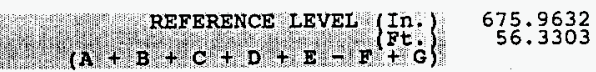

* IMMERSION DEPTH CALCULATION

GOVERNING EQUATION

$H=(4 \star \mathrm{Fb}) /\left(\mathrm{Sg}^{\star} \mathrm{P} i \star D * \star 2\right)$

$\mathrm{Fb}=$ BOUYANT FORCE $=$ SET POINT $=15.0000$ GRAMS

$S g=$ SPECIFIC GRAVITY OF LIQUID =

1.0500

$D=$ DISPLACER DIAMETER =

2.0000 INCHES

IMMERSION DEPTH (FROM EQUATION) =

0.7048 CENTIMETERS

0.2775 INCH 


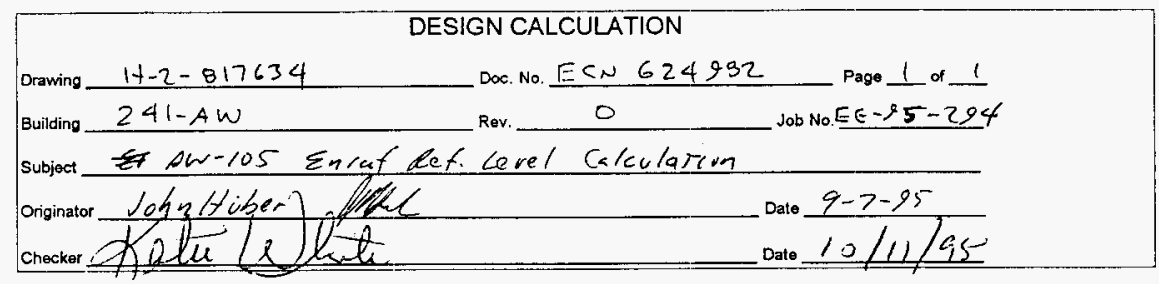

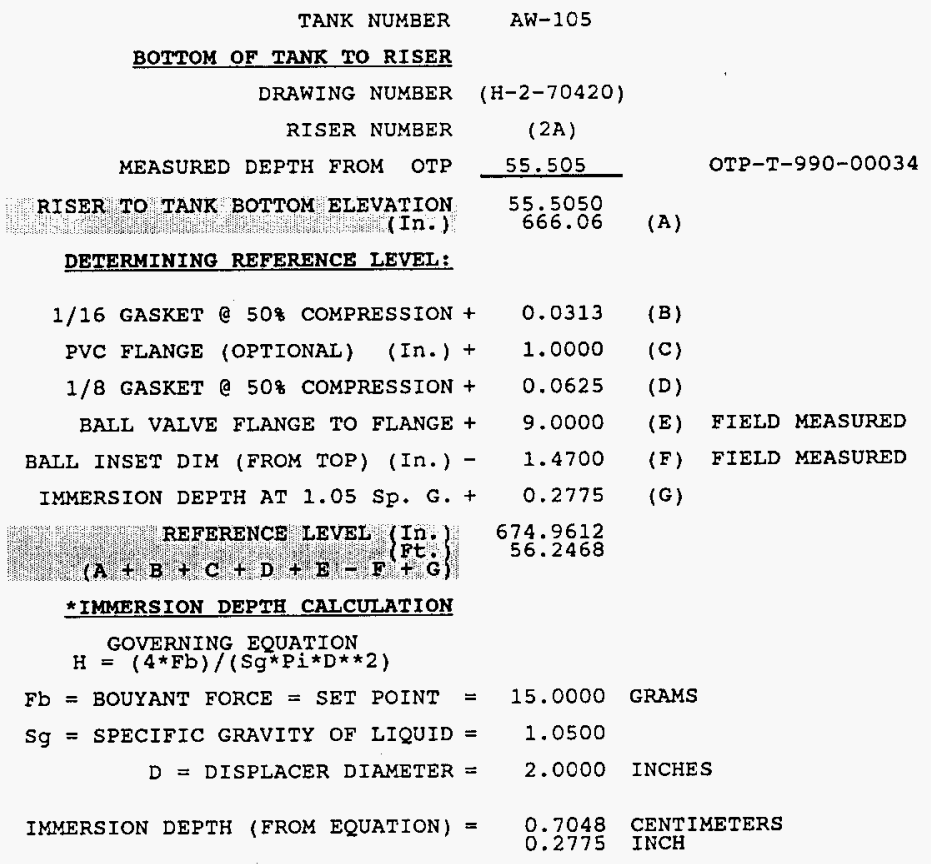




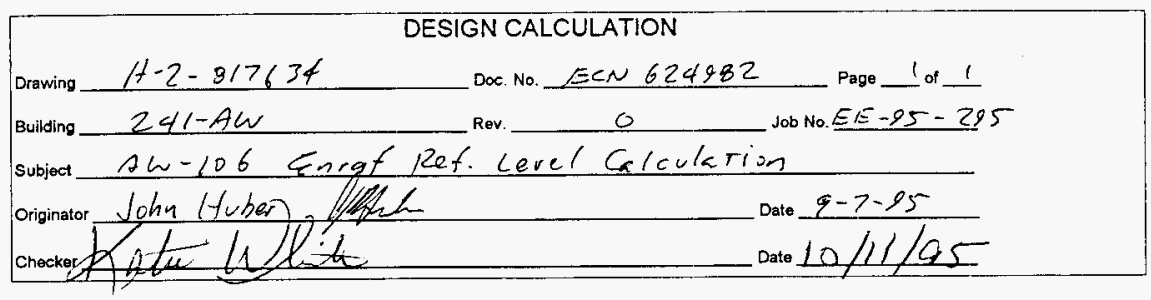

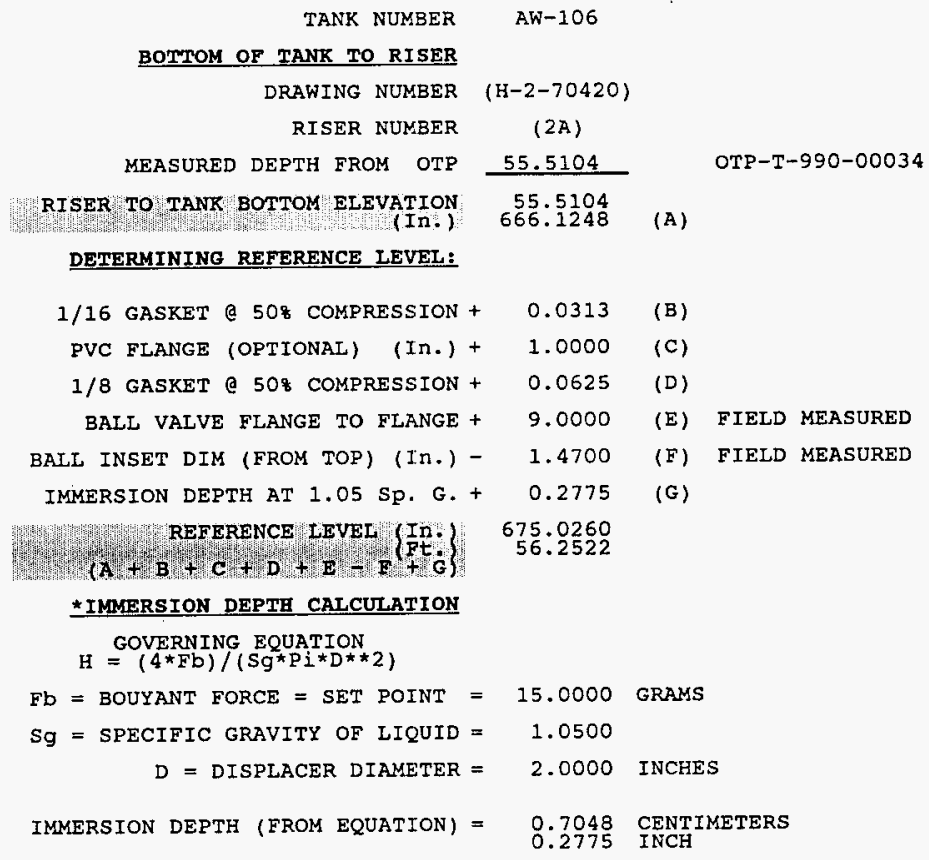



(1) Drawing $1 \mathrm{f}-2-917634$
(2) Doc. No
(3) Page
of
(4) Building $241-4 x$
(5) Rev
1
(6) Job No.
(7) Subject $241-4 X-10$
Enraf Reference Lerel Calculation
(9) Checker
micend es gohana
Date $3-29.95$
Date $3 / 2 q / 95$

(10)

TANK NUMBER AX-101

PARAMETERS

BOTTOY OF TANK TO RISER DIMENSION

$T T=652.07625$

$\mathrm{UR}=652.07625$

DRAWING NUMBER (H-2-37854)

$\mathrm{MH}=676.67625$

RISER NUMBER

(8C)

RISER ELEVATION (Ft.)

681.6600

TANK INSIDE BOTTOM ELEVATION (Et.) - 628.4200

TANK SIDE-BOTTOM ELEVATION (Ft.) $N / A$

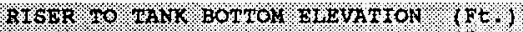

$(\mathrm{In})$

53.2400

638.88

(A)

$\mathrm{HH}=671.07625$

$\mathrm{HA}=664.07625$

$\mathrm{RL}=652.07625$

$A N=N / A$

$A M=N / A$

$\mathrm{TI}=\mathrm{AX101}$

$\mathrm{ML}=6.0000$

$L A=12.0000$

$\mathrm{LL}=1.0000$

$\mathrm{WT}=\mathrm{EDE}$

\section{DETERMINING REFERENCE LEVEL:}

1/16 GASKET a 508 COMPRESSION (In.) +

0.0313

(B)

PVC FLANGE (OPTIONAL) (In.) +

1.0000

(C)

1/8 GASKET a 508 COMPRESSION (In.) +

0.0625

(D)

BALL VALVE FLANGE TO FLANGE (In.) +

9.0000

(E)

BALI INSET DIM (FROM TOP) (In.) -

1.2100

(F)

IMMERSION DEPTH IN SOLIDS (In.) +

0 (G)

I 6" TO 4" ADDAPTER SPOOL (In.) +

4.2500

(H) (field dimension)

1

1/8 GASKET @ 508 COMPRESSION (In.) +

0.0625

(I)

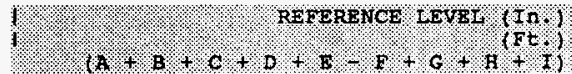

652.0763

54.3397 
WHC-SD-WM-CN-078

REVISION 0

THIS PAGE RESERVED FOR AX-102

A-31 

(1) Drawing $1+-2-817634$
(4) Building $241-A X$
(2) Doc. No.
(5) Rev.
1
(3) Page
(6) Job No. of 1
(7) Subject 241-AX-103 Encaf Reference Cevel Calchation
(8) Originator John Huber thwh Date $3-29-75$
(9) Checker mirel is gonsm Date $3 / 29 / 95$

TANK NUMBER

BOTTON OF TAKR TO RISER DIMENSION

DRAWING NUMBER

(H-2-37854)

RISER NUMBER

RISER ELEVATION (Ft.) 681.6400

TANK INSIDE BOTTOM ELEVATION (Ft.) - 628.4200

TANK SIDE-BOTTOM ELEVATION (Ft.) RT SBR TO TAMK BOTTOM BLEYATION (Ft.) (In.)

DETERMINING REEERENCE LEVEL:

1/16 GASKET $50 \%$ COMPRESSION (In.) + PVC FLANGE (OPTIONAL) (In.) + 1/8 GASKET @ $50 \%$ COMPRESSION (In.) + BALL VALVE FLANGE TO FLANGE (In.) + BALL INSET DIM (FROM TOP) (In.) IMMERSION DEPTH IN SOLIDS (In.) + 6" TO 4" ADDAPTER SPOOL (In.) +

1/8 GASKET a 50 Z COMPRESSION (In.) +

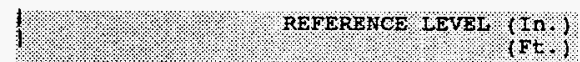

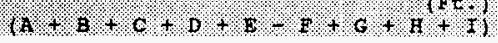

(9C)

$\mathrm{Ax}-103$ $N / A$

53.2200 638.64

(A)

0.0313

(B)

1.0000

(c)

0.0625

(D)

9.0000

1.2100

0

(G)

4.2500

(H) (sield dimension)

0.0625

(I)
PARAMETERS

$\mathrm{TT}=651.83625$

$\mathrm{UR}=651.83625$

$\mathrm{MH}=676.43625$

$\mathrm{HH}=670.83625$

$\mathrm{HA}=663.83625$

$R L=651.83625$

$A N=N / A$

$A M=N / A$

$\mathrm{TI}=\mathrm{AX} 103$

$M L=1.00006 .00 \% / 4$

$\mathrm{LA}=12.0000$

LL $=6.0000-1.00 \%$

$W T=E D E$ 


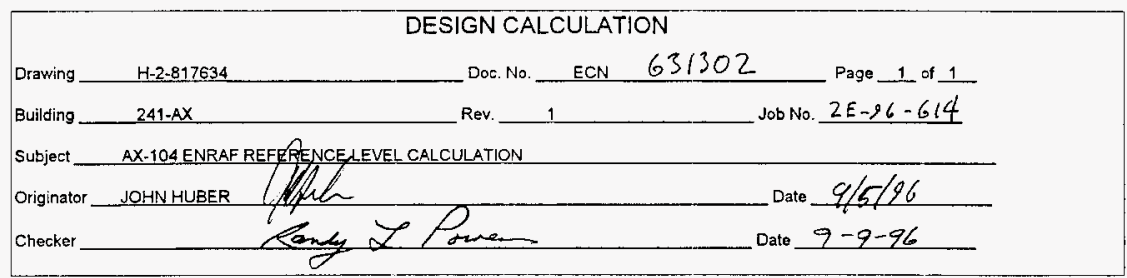

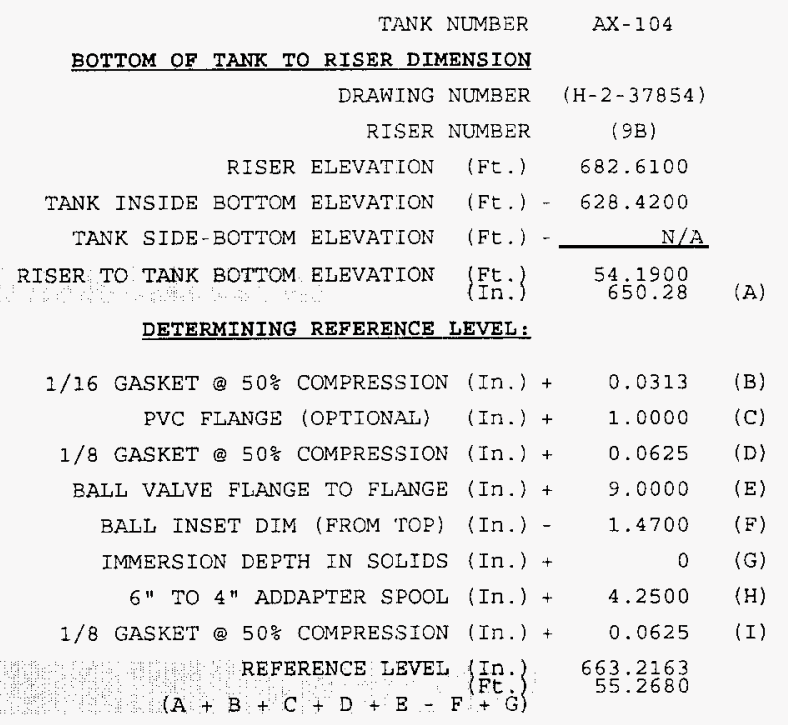




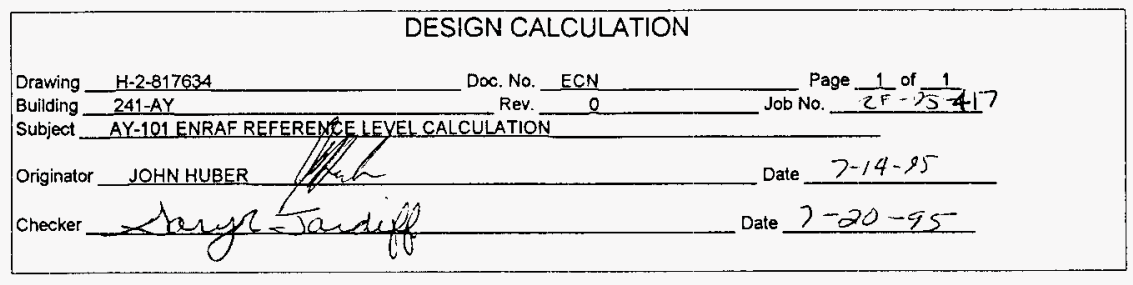

TANK NUMBER AY-101

BOTTOM OF TANK TO RISER DIMENSION

DRAWING NUMBER H-2-37911

RISER NUMBER (22A)

RISER ELEVATION (Ft.) 680.5000

FIELD MEASURED PER KEH SURVEY

RISER ELEVATION (Ft.) 680.5000

DATA REPORT 2EAY-006

TANK BOTTOM ELEVATION (Ft.) $-\begin{array}{r}623.2300 \\ \text { RISER TO TANK BOTTOM ELEVATION }\end{array} \begin{array}{r}57.2700 \\ 687.24\end{array}$

H-2-37911

(A)

DETERMINING REFERENCE LEVEL:

$1 / 16$ GASKET @ 508 COMPRESSION +

0.0313

(B)

PVC FLANGE (OPTIONAL) (In.) +

0.0000

(C)

$1 / 8$ GASKET a $50 \%$ COMPRESSION +

0.0000

BALI VALVE FLANGE TO FLANGE (In.) +

9.0000

(E)

BALI INSET DIM (FROM TOP) (In.) -

1.4700

IMMERSION DEPTH (In.) +

0.2654

(F)

(G)

NEW BALL VALVE PER
H-2-817634 PIN 48

695.0666
57.9222

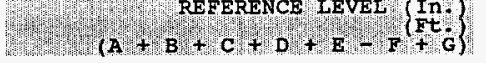

\section{* IMMERSION DEPTH CALCULATION}

GOVERNING EQUATION

$\mathrm{H}=(4 * \mathrm{Fb}) /\left(\mathrm{Sg} * P i \star D^{\star \star} 2\right)$

$\mathrm{Fb}=$ BOUYANT FORCE $=$ SET POINT $=$

15.0000 GRAMS

$S g=$ SPECIFIC GRAVITY OF LIQUID =

1.0980

$D=$ DISPLACER DIAMETER =

2.0000 INCHES

H = IMMERSION DEPTH (FROM EQTN) $=$

0.6740 CENTIMETERS 


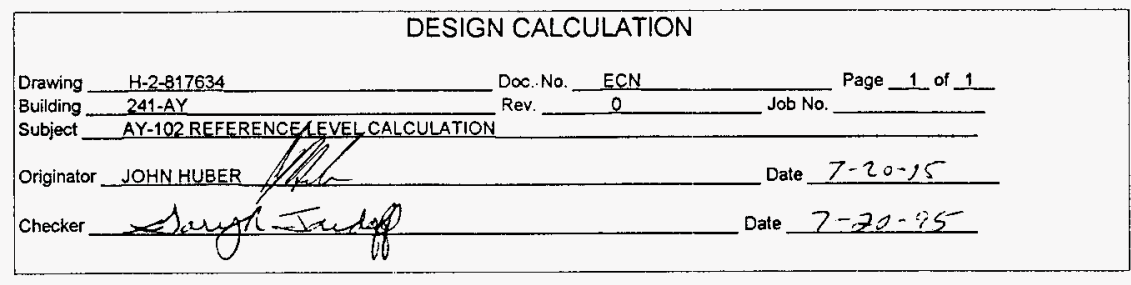

$$
\text { TANK NUMBER AY-102 }
$$

\section{BOTTOM OF TANK TO RISER DIMENSION}

$\begin{array}{rccc}\text { DRAWING NUMBER } & \text { H-2-37911 } \\ \text { RISER NUMBER } & (22 \mathrm{~A}) & \\ \text { RISER ELEVATION } & (\text { Ft.) } & 680.6300 & \text { FIELD MEASURED PER KEH SURVEY } \\ \text { DATA REPORT 2EAY-006 }\end{array}$

$$
\begin{array}{lr}
\text { TANK BOTTOM ELEVATION (Ft.) } & -623.2300 \\
\text { RISER TO TANK BOTTOM ELEVATION } & 57.4000 \\
688.8
\end{array}
$$$$
\text { H-2-37911 }
$$

DETERMINING REFERENCE LEVEL:

1/16 GASKET \& $50 \%$ COMPRESSION +

0.0313

PVC FLANGE (OPTIONAL) (In.) +

0.0000

$1 / 8$ GASKET \& $50 \%$ COMPRESSION +

0.0000

BALL VALVE FLANGE TO FLANGE (In.) +

9.0000

BALL INSET DIM (FROM TOP) (In.) -

1.4700

IMMERSION DEPTH (In.) +

0.2802

NEW BALL VALVE PER H-2-817634 P/N 48

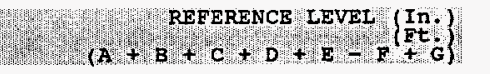

\section{* IMMERSION DEPTE CALCULATION}

GOVERNING EQUATION

$H=(4 * F b) /(S g \star P i \star D \star \star 2)$

$\mathrm{Fb}=$ BOUYANT FORCE $=$ SET POINT $=$

$\mathrm{Sg}$ = SPECIFIC GRAVITY OF LIQUID =

$D=$ DISPLACER DIAMETER =

$\mathrm{H}=$ IMMERSION DEPTH (FROM EQTN) =
696.6414
58.0535

15.0000 GRAMS

1.0400

2.0000 INCHES

0.7116 CENTIMETERS 


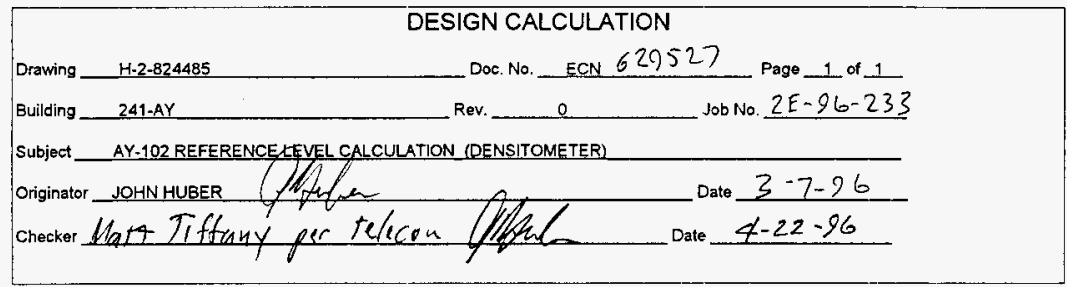

\section{BOTTOM OF TANK TO RISER DIMENSION}

DRAWING NUMBER

RISER NUMBER

RISER ELEVATION (FC.)

INSIDE BOTTOM OF TANK ELEVATION (Ft.)

RISER TO TANK BOTTOM ELEVATION \{Ft.\}

\section{DETERMINING REPERENCE LEVEL:}

$1 / 16$ GASKET @ 50\% COMPRESSION (In.) + ADDAPTER SPOOL, ASSY -030 (In.) +

$1 / 16$ GASKET @50\% COMPRESSION (In.) +

BALL VALVE FLANGE TO FLANGE (In.) + BALI INSET DIM (FROM TOP) (In.) -

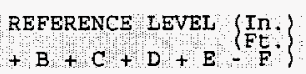

AY-102

(H-2-37911)

(15S)

680.1100

623.2300

56.8800

(A)
(B)

(C)

(D)

(E)

(F) FLOW-TEK BALL VALVE, H-2-824485, ITEM 26, FIELD MEASURED 
TANK NUMBER

A $2-101$

BOTTOM OF TANK TO RISER DIMENSION

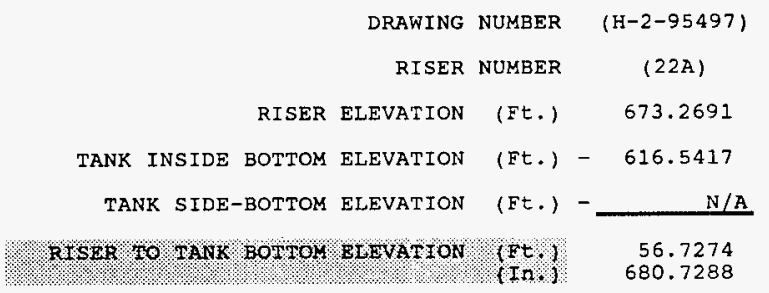

DETERMINING REFERENCE LEVEL:

$1 / 16$ GASKET \& $50 \%$ COMPRESSION (In.) + PVC FLANGE (OPTIONAL) (In.) + 1/8 GASKET @ 508 COMPRESSION (In.) + BALL VALVE FLANGE TO FLANGE (In.) + BALL INSET DIM (FROM TOP) (In.) IMMERSION DEPTH AT $1.05 \mathrm{sp.} \mathrm{G.} \mathrm{(In.)}$ REBER INCE LBVEL $(\mathrm{Ia}$.) $01001 \mathrm{PH}$. $(\mathrm{A}+\mathrm{B}+\mathrm{C}+\mathrm{D}+\mathrm{B}+\mathrm{P}+\mathrm{G}$

\section{^ IMMERSION DEPTH CALCULATION}

GOVERNING EQUATION

$\mathrm{H}=(4 * \mathrm{Fb}) /(\mathrm{Sg} * \mathrm{Pi} * \mathrm{D} * 2)$

$\mathrm{Fb}=$ BOUYANT FORCE = SET POINT $=$

$\mathrm{Sg}=$ SPECIFIC GRAVITY OF LIQUID =

$$
D=\text { DISPLACER DIAMETER = }
$$

$H$ = IMMERSION DEPTH (FROM EQUATION) =

$$
\begin{array}{rr}
0.0313 & \text { (B) } \\
N / A & \text { (C) } \\
N / A & \text { (D) } \\
9.0000 & \text { (E) } \\
1.2100 & \text { (F) }
\end{array}
$$

0.2774923

688.8275

57.4023
PARAMETERS

$\mathrm{TT}=713.48$

$U R=713.48$

$\mathrm{MH}=707.88$

$\mathrm{HH}=700.88$

$\mathrm{HA}=694.88$

$\mathrm{RL}=688.83$

$\mathrm{AN}=377.00$

$A M=327.00$

$\mathrm{TI}=. \mathrm{AZ101}$

$\mathrm{MI}=1.00$

$\mathrm{LA}=12.00$

$L L=6.00$

$W T=E D E$ 


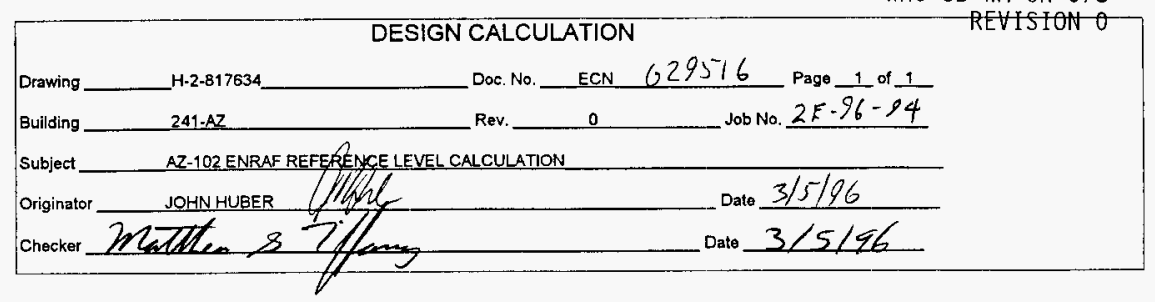

TANK NUMBER AZ-102

BOTTOM OF TANR TO RISER DIMENSION

DRAWING NUMBER

RISER NUMBER
RISER ELEVATION (Ft.)

(H-2-95497)

(22A)

$672.7500 \quad \mathrm{H} \cdot 2 \cdot 70202$

TOP OF 16" FLG. TO 4" FLG (Ft.) +

$0.5885 \quad \mathrm{H}-2-94872$

$1 / 16$ GASKET \& 50\% COMP. (Ft.) + 16" RF FLG THICKNESS (Ft.) +

TOP OF CONC. FOUNDATION (Et.) ANN. BOTTOM PL. THICKNESS (Ft.) -

0.0026

0.1200

615.8000

TIT GRINNELL
FLANGE DATA

0.0313

INSULATING CONC. THICKNESS (Ft.) -

PRI. BOTTOM PL. THICKNESS (Ft.) -

RISER TO TANK BOTTOM ELEV (

0.6667

0.0417

\section{DETERMINING REFERENCE LEVEI:}

56.9214
683.0568

(A)

$1 / 16$ GASKET $@ 50 \%$ COMPRESSION (In.) + PVC FLANGE (OPTIONAL) (In.) +

0.0313

H-2-67397

$1 / 8$ GASKET @ 50\% COMPRESSION (In.) +

$\mathrm{N} / \mathrm{A} \quad$ (C)

BALL VALVE FLANGE TO FLANGE (In.) +

$\mathrm{N} / \mathrm{A} \quad$ (D)

BALL INSET DIM (FROM TOP) (In.) -

9.0000

1.4700

FIELD MEASURED FROM H-2-817634, PIN 48

IMMERSION DEPTH AT $1.1 \mathrm{Sp}$. G. (In.) +

0.2649

(G)

690.8829
57.5736

$\mathrm{C}+\mathrm{B}+\mathrm{C}+\mathrm{D}+\mathrm{E}-\mathrm{F}+\mathrm{G}\}$

* IMMERSION DEPTH CALCULATION

$H=\left(\begin{array}{l}\text { GOVERNING EQUATION } \\ 4 * \mathrm{Fb}) /(\mathrm{Sg} * \mathrm{P} 1 * \mathrm{D} \star \star 2)\end{array}\right.$

$\mathrm{Fb}=$ BOUYANT FORCE = SET POINT $=$

15.0000 GRAMS

$\mathrm{Sg}=$ SPECIFIC GRAVITY OF LIQUID =

1.1000

$D=$ DISPILACER DIAMETER =

2.0000 INCHES

$H=$ IMMERSION DEPTH (FROM EQUATION) =

$\begin{array}{ll}0.6728 & \text { CENTIMETERS } \\ 0.2649 & \text { INCH }\end{array}$ 


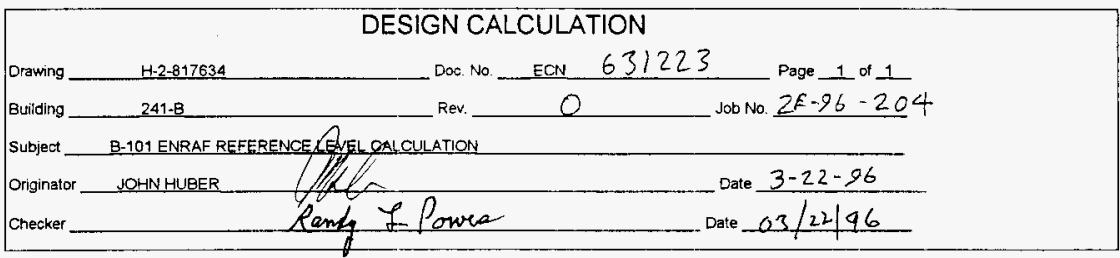

$$
\text { TANK NUMBER B-101 }
$$

BOTTOM OF TANK TO RISER DIMENSION

DRAWING NUMBER (H-2-37851)

RISER NUMBER (8)

RISER ELEVATION (Ft.) 654.2100

TANK CL BOTTOM ELEVATION (Ft.) - 615.0000

RISER TO TANK BOTTOM ELEVATION 39.2100

\section{DETERMINING REFERENCE LEVEL:}

\section{1/16 GASKET @ 50\% COMPREŞSION + 0.0313 (B)}

FVC FLANGE (OPTIONAL) (In.) + 1.0000 (C)

$1 / 8$ GASKET @ 50\% COMFRESSION (In.) + 0.0625 (D)

BALL VALVE FLANGE TO FLANGE (In.) + 9.0000 (E)

BALL INSET DIM (FROM TOP) (In.) - 1.4700 (F)

IMMERSION DEPTH IN SOLIDS (In.) + 0 (G)

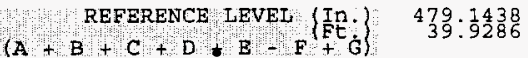



(1) Drawing $H-2-817634$
(2) Dor. No. (3) Page 1 of ?
(4) Building $241-B$
(5) Rev. 1
$-$
(7) Subject $\angle B-102 \quad E n r a$
(8) Originator Vohn /tuber
(9) Checker miand as dinas
(6) Job No.

Reason for revision: Previous calc. bred on 12 gram rather than 15 gram delia ses point.

TANK NUMBER B-102

BOTTOM OF TANR TO RISER DIMENSION

DRAWING NUMBER (H-2-37851)

RISER NUMBER

RISER ELEVATION (Ft.)

653.6700

TANK INSIDE BOTTOM ELEVATION (Ft.) -

N/A

TANK SIDE-BOTTOM ELEVATIO

(Ft.) -615.0000

\section{RISEA IO TAUK BOTTOY ALEVATION : (Bt.)}

(In.)

38.6700

464.04

(A)

\section{DETERYINING REFERENCE LEVEL:}

$1 / 16$ GASKET \& 508 COMPRESSION (In.) +0.0313

PVC FLANGE (OPTIONAL) (In.) +

1.0000

$1 / 8$ GASKET @ $50 \%$ COMPRESSION (In.) +

0.0625

BALL VALVE FLANGE TO FLANGE (In.) +

9.0000

BALI INSET DIM (FROM TOP) (In.) -

1.2100

(F)

IMMERSION DEPTH AT $1.05 \mathrm{sp}$. G. (In.)

0.2774923

$(\mathrm{G})=$

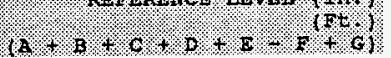

* IMMERSION DEPTH CALCULATION

$$
\begin{aligned}
& \text { GOVERNING EQUATION } \\
& H=(4 \star F b) /(S g \star P i \star D \star \star 2) \\
& \mathrm{Fb}=\text { BOUYANT FORCE }=\text { SET POINT }=15.0000 \text { GRAMS } \\
& \mathrm{Sg}=\text { SPECTFIC GRAVITY OF LIQUID }=1.0500 \\
& \mathrm{D}=\text { DISPLPCER DIAMETER }=2.0000 \text { INCHES } \\
& \mathrm{H}=\text { IMMERSION DEPTH (FROM EQUATION) }= \\
& 0.7048 \text { CENTIMETERS } \\
& 0.2775 \text { INCH }
\end{aligned}
$$

39.4334 
WHC-SD-WM-CN-078

REVISION 0

THIS PAGE RESERVED FOR B-103

A- 41 
WHC-SD-WM-CN-078

REVISION 0

THIS PAGE RESERVED FOR B-104 
WHC-SD-WM-CN-078

REVISION 0

THIS PAGE RESERVED FOR B-105 
THIS PAGE RESERVED FOR B-106 
WHC-SD-WM-CN-078

REVISION 0

THIS PAGE RESERVED FOR B-107 
THIS PAGE RESERVED FOR B-108 
WHC-SD-WM-CN-078

REVISION 0

THIS PAGE RESERVED FOR B--109 
WHC-SD-WM-CN-078

REVISION 0

THIS PAGE RESERVED FOR B-110 
WHC-SD-WM-CN-078

REVISION 0

THIS PAGE RESERVED FOR B-111 

(1) Drawing
$1+2-817634$
(2) DoC. No.
(3) Page $l$ of 1

(4) Building $241-13$

(5) Rev

2

(7) Subject B-112 Eniaf Ref. Level Cakulations

(8) Originator John Ituber

Date $4 \cdot 4 \cdot 95$

(9) Checker mered is onentax Date $4=10-95$

(10) Reason for revision: Previous calcs used curong ball value dimension. Howeve, gauge in field accounts for correct ball valve and wrong delta for sexpoint.

TANK NUMBER B-112

BOTTOY OF TANK TO RISER DIMENSION

DRAWING NUMBER (H-2-37851)

RISER NUMEER

(4)

RISER ELEVATION (Et.) 652.6400

TANK INSIDE BOTTOM ELEVATION (Ft.) - N/A

TANK SIDE-BOTTOM ELEVATION (Ft.) - 614.0000

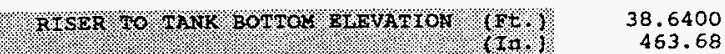

(A)

DETERMINING REFERENCE LEVEL:

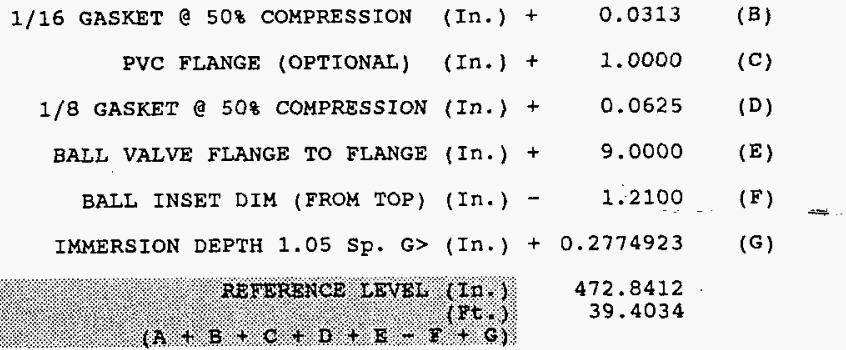

\section{* IMOEERSION DEPTH CALCULATION}

GOVERNING EQUATION

$H=(4 * \mathrm{Fb}) /(\mathrm{Sg} * \mathrm{Pi} * \mathrm{D} * * 2)$

$\mathrm{Fb}=$ BOUYANT FORCE $=$ SET POINI

15.0000 GRAMS

$\mathrm{Sg}=$ SPECIFIC GRAVITY OF LIQUID $=1.0500$

$\mathrm{D}=\mathrm{DISPLACER}$ DIAMETER $=\quad 2.0000$ INCHES

$\mathrm{H}=$ IMMERSION DEPTH (FROM EQUATION) =

0.7048 CENTIMETERS

0.2775 INCH 
WHC-SD-WM-CN-078

REVISION 0

THIS PAGE RESERVED FOR B-201 


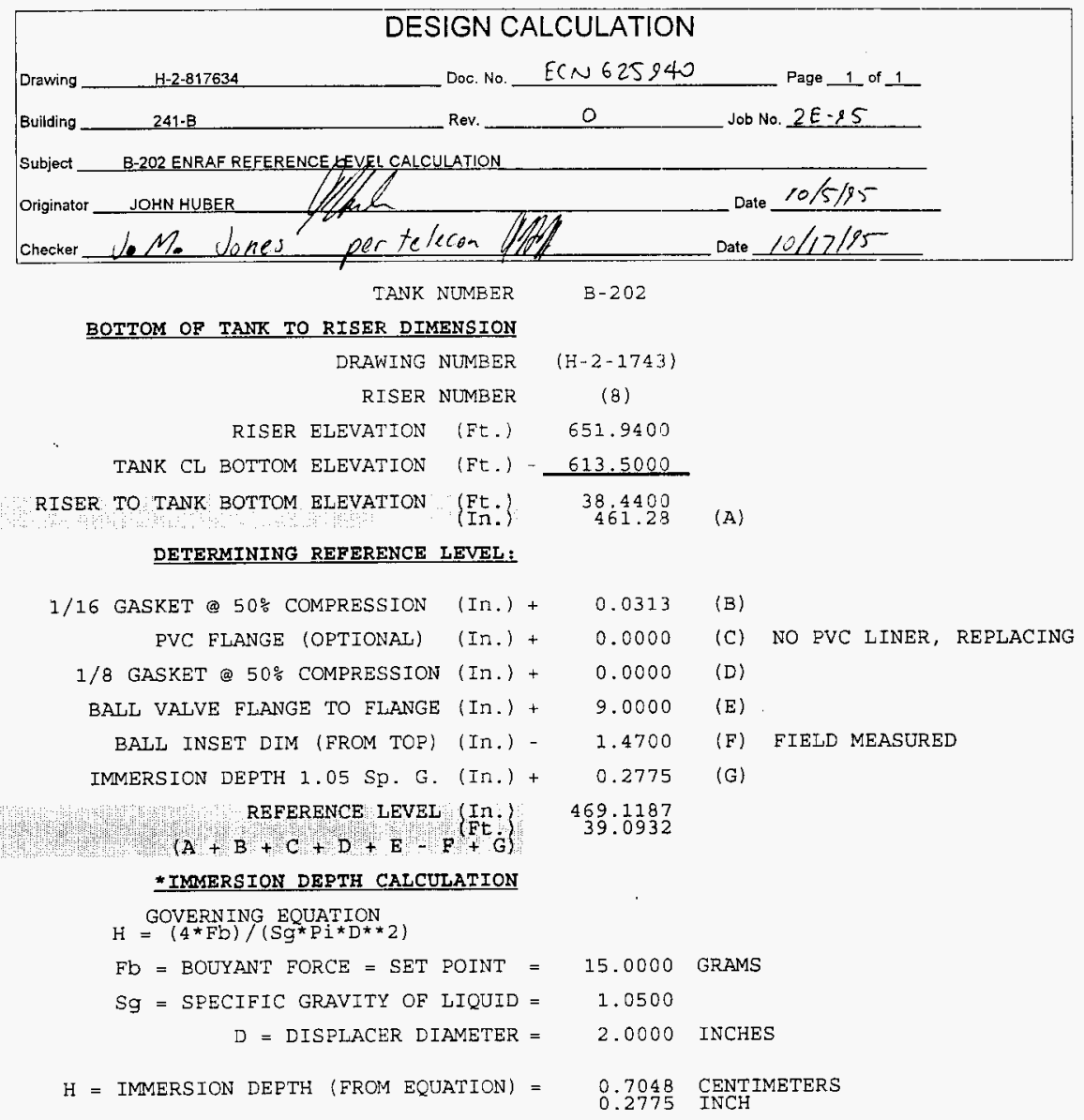


THIS PAGE RESERVED FOR B-203 
THIS PAGE RESERVED FOR B-204 


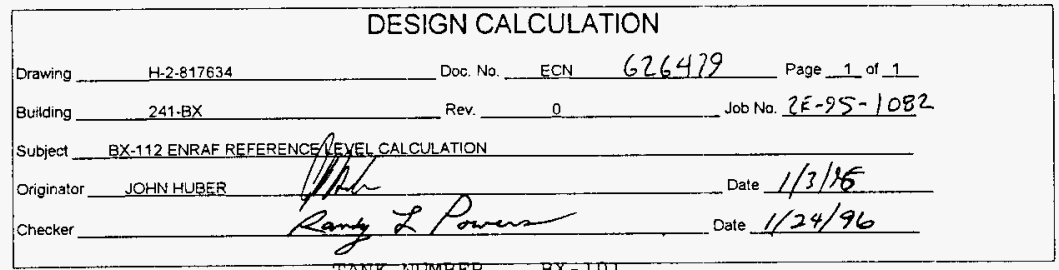

TANK NUMBER

BO'TTOM OF TANK TO RISER DIMENSION

DRAWING NUMBER ( $\mathrm{H}-2-37852)$

RISER NUMBER

(8)

RISER ELEVATION (Ft.) 657.0100

TANK CL BOTTOM ELEV (Ft.) - 616.0000

RISER TO TANK BOTTOM ELEV ( Ft: 491.0100

(A)

DETERMINING REFERENCE LEVEL:

$1 / 16$ GSKT @ 50\% COMPRESSION (In.) +

PVC FLANGE (OPTIONAI) (In.) +

$1 / 8$ GSKT @ 50\% COMPRESSION (In.) +

BALL VALVE FLANGE TO FLANGE (In.) +

BALI INSET DIM (FROM TOP) (In $)$ -

IMMERSION DEPTH IN SP. G. (In.) +

REFERENCE LEVEL ( $\mathrm{In}$.)

0.0313

(B)

1.0000

(C)

0.0625

(D)

9.0000

(E)

$1.4700 \quad$ (F)

0.2775 (G)

$(A+B+C+D+B-F+G$

501.0212

\section{* IMMERSION DEPTH CALCULATION}

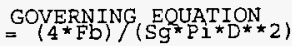

$\mathrm{Fb}=$ BOUYANT FORCE $=$ SET POINT $\Rightarrow 15.0000$ GRAMS

$\mathrm{Sg}=$ SPECIFIC GRAVITY OF LIQUID $=1.0500$

$\mathrm{D}=$ DISPLACER DIAMETER $=2.0000$ INCHES

$\mathrm{H}=$ IMMERSION DEPTH (FROM EQUATION) $=0.7048$ CENTIMETERS 


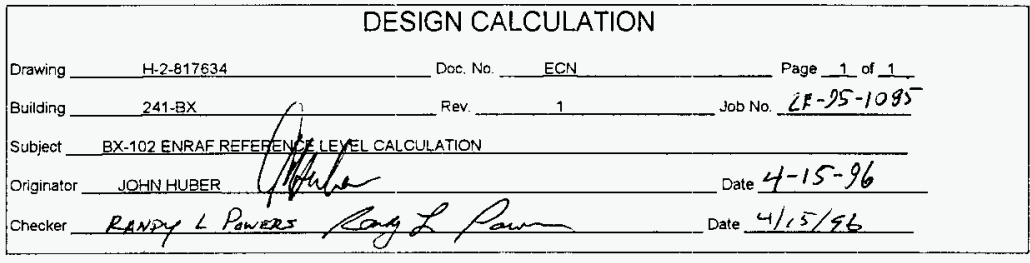

TANK NUMBER

BOTTOM OF TANK TO RISER DIMENSION

RISER NUMBER

$\mathrm{BX}-102$

\section{DRAWING NUMBER}

(H-2-37852)

RISER ELEVATION (Ft.)

(2)

TANK CL BOTTOM ELEV

(FE.) - 615.0000

$$
\text { RISER TO TANK BOTTOM ELEV (Ft.) } 41 \text { (In) } 1900
$$

\section{DETERMINING REFERENCE LEVEL;}

1/16 GSKT @ 50\% COMPRESSION (In.) +

0.0313

(A) PVC FLANGE (OPTIONAL)

$(\operatorname{In})+$.

0.0000

(B)

SLIP-ON FLANGE (In.) +

2. 1875

12" PIPE LENGTH (In.) +

18.0000

SIIP-ON FLANGE (In.) +

2.1875

1/16 GSKT @ 50\% COMPRESSION (In.) +

0.0313

(C)

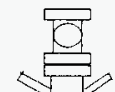

DUAI FORT FLANGE THKNESS ( $\left.\mathrm{I}_{+}\right)+$

1.2500

1/16 GSKT @ 50\% COMPRESSION (In.) +

0.0313

(H)

(I) OBSV PT/BREATHER PER H2.93727 DET. 4

BALL VALVE FLANGE TO FLANGE (In.) +

9.0000

(J)

BALI INSET DIM (FROM TOP) (In.) -

1.4700

IMMERSION DEPTH IN SOLIDS (In.) +

REFERENCE LEVEL (In:)

$A+B+C+H+1+1+K+L+M+D+E+F+G$

524.4489

(K)

(L) PER H-2-E17634 ASSY \&A

(M)

(E)

(F) FiELD MEASUREO

(G)

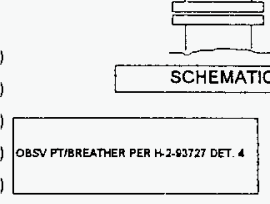




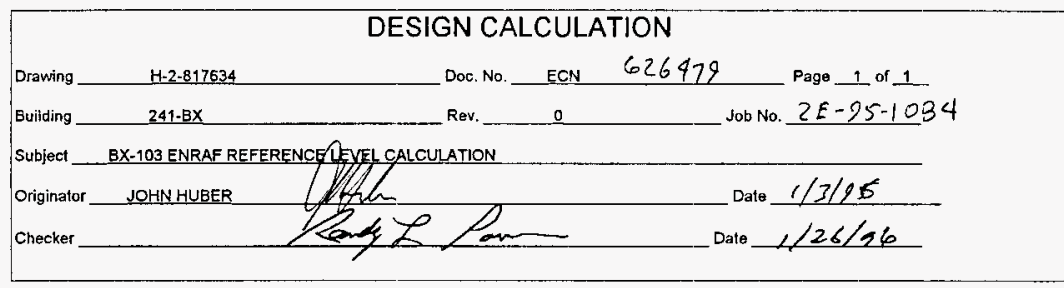

\section{DESIGN CALCULATION}

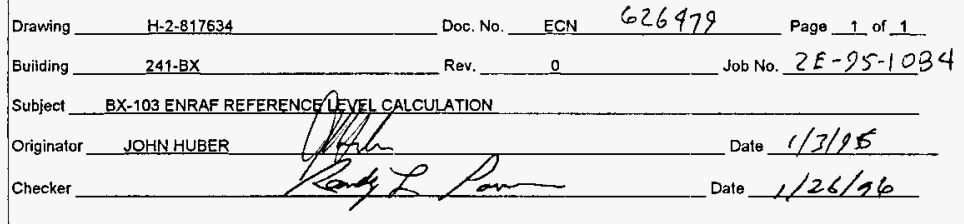

TANK NUMBER BX-103

BOTTOM OF TANK TO RISER DIMENSION

DRAWING NUMBER (H-2-37852)

RISER NUMBER (8)

RISER ELEVATION (Ft.) 655.0400

TANK CL BOTTOM ELEV (Ft.) - 614.0000

RISER TO TANK BOTTOM ELEV (FE.) 41.0400

DETERMINING REFERENCE LEVEL:

1/16 GASKET @ 50\% COMPRESSION (In.) +

0.0313

PVC FLANGE (OPTIONAL) (In.) +

1.0000

(C)

1/8 GASKET @ 50\% COMPRESSION (In.) +

0.0625

BALL VALVE FLANGE TO FLANGE (In.) +

9.0000

BALL INSET DIM (FROM TOP) (In.) -

1.4700

IMMERSION DEPTH AT $1.05 \mathrm{Sp}$. G. (In.) +

0.2775

(G)

$\left.\begin{array}{l}\text { REFERENCE LEVEL }\{\text { In } \\ (\mathrm{A}+\mathrm{B}+\mathrm{C}+\mathrm{D}+\mathrm{B}-\mathrm{F}+\mathrm{G}\end{array}\right\} \begin{array}{r}501.3812 \\ 41.7818\end{array}$

\section{* IMMERSION DEPTH CALCULATION}

$\mathrm{H}=\left(4^{\star} \mathrm{Fb}\right) /\left(\mathrm{Sg}^{\star} \mathrm{P} i \star \mathrm{D}^{\star} \star 2\right)$

$\mathrm{Fb}=$ BOUYANT FORCE $=$ SET POINT $=15.0000$ GRAMS

$\mathrm{Sg}=$ SPECIFIC GRAVITY OF LIQUID =

1.0500

$D=$ DISPLACER DIAMETER =

2.0000 INCHES

$H=$ IMMERSION DEPTH (FROM EQUATION) =

0.7048 CENTIMETERS 


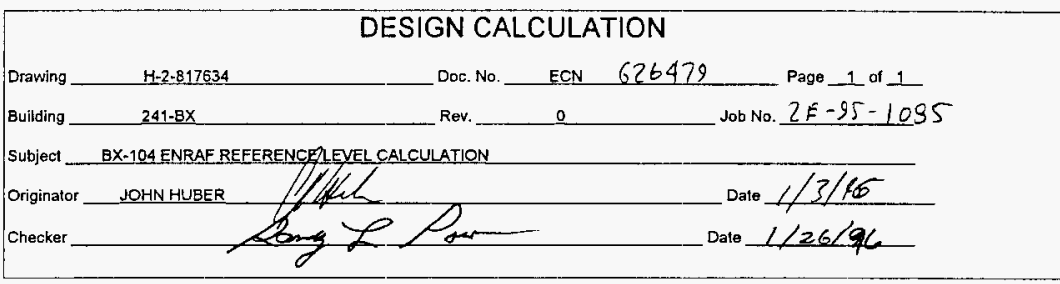

TANK NUMBER BX-104

BOTTOM OF TANK TO RISER DIMENSION

DRAWING NUMBER (H-2-37852)

RISER NUMBER (8)

RISER ELEVATION (Ft.) 657.0900

TANK CL BOTTOM ELEV (Ft.) - 616.0000

RISER TO TANK BOTTOM ELEV (Et.) $4 \frac{1}{1} .0900$ (A)

DETERMINING REFERENCE LEVEL:

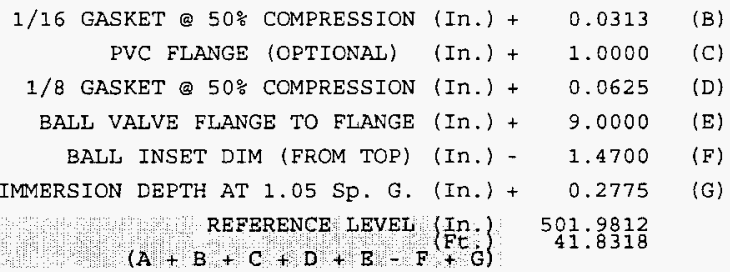

* IMMERS ION DEPTH CALCULATION

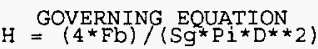

$\mathrm{Fb}=$ BOUYANT FORCE $=$ SET POINT $=15.0000$ GRAMS

$S g=$ SPECIFIC GRAVITY OF LIQUID $=1.0500$

$D=$ DISPLACER DIAMETER $=2.0000$ INCHES

$\mathrm{H}=$ IMMERSION DEPTH (FROM EQUATION) $=\begin{aligned} & 0.7048 \text { CENTIMETERS } \\ & 0.2775 \text { INCH }\end{aligned}$ 


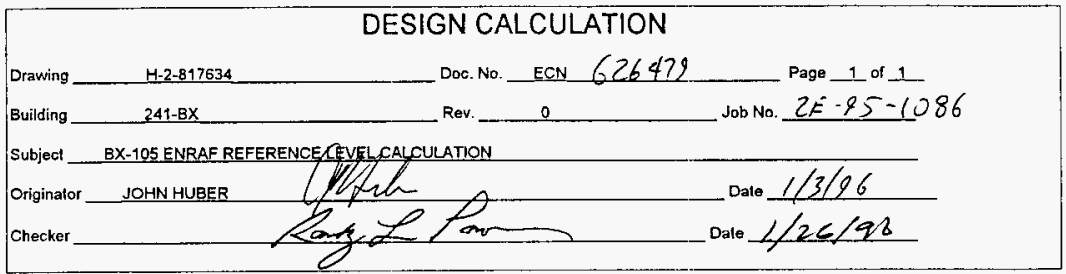

TANK NUMBER BX-105

BOTIOM OF TANK TO RISER DIMENSION

DRAWING NUMBER

RISER NUMEER

$(\mathrm{H}-2-37852)$

(1)

RISER ELEVATION (Ft.) 656.4700

TANK CI BOTTOM ELEV (Ft.) - 615.0000

RISER TO TANK BOTTOM ELEV ( FE : $\quad \begin{array}{r}41.4700 \\ 497.64\end{array}$

(A)

DETERMINING REFERENCE LEVEL:

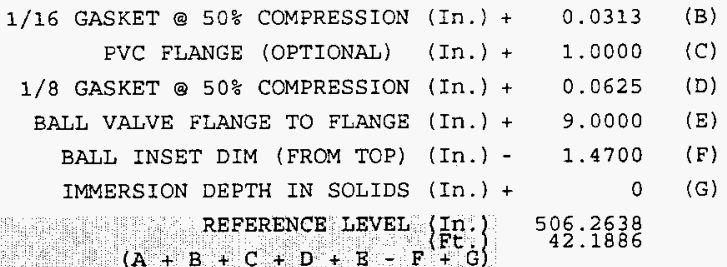




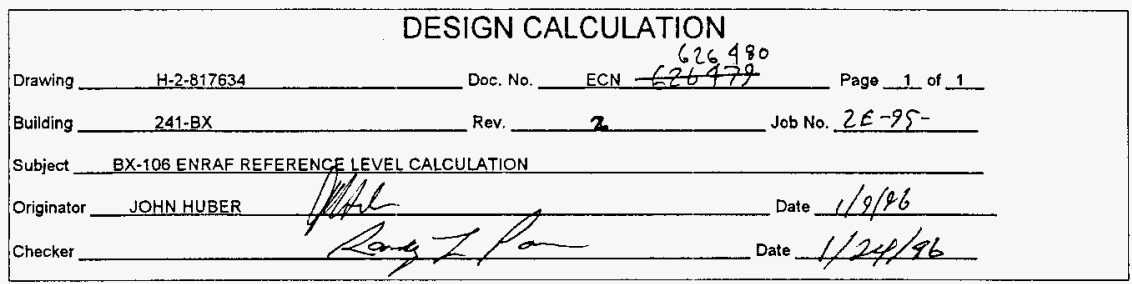

TANK NUMBER BX-106

BOTTOM OF TANK TO RISER DIMENSION

DRAWING NUMBER (H-2-37852)

RISER NUMBER

(8)

RISER ELEVATION (Ft.) 654.9300

TANK CL BOTTOM ELEV (Ft.) - 614.0000

RISER TO TANK BOTTOM ELEV (Ft.) 40.9300

(A)

DETERMINING REPERENCE LEVEL:

1/16 GSKT @50\% COMPRESSION (In.) PVC FLANGE (OPTIONAL) (In.)

1/8 GSKT @ 50\% COMPRESSION (In.)

BALL VALVE FLANGE TO FLANGE (In.)

BALL INSET DIM (FROM TOP) (In.)

$+0.0313$

(B)

IMMERSION DEPTH IN SOLIDS (In.)

+1.0000 (C)

+0.0625 (D)

+9.0000 (E)

-1.2100 (F)

$\left.\begin{array}{r}\text { REFERENCEYLEVEL ( In } \\ \text { Ft }\end{array}\right\} \quad \begin{array}{r}500.0437 \\ \mathbf{4} 1.6703\end{array}$ 


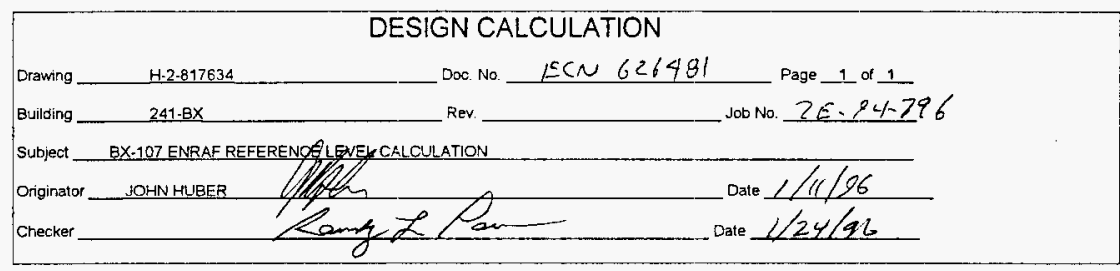

\section{TANK NUMBER BX-107}

BOTTOM OF TANK TO RISER DIMENSION

DRAWING NUMBER ( $\mathrm{H}-2-37852)$

RISER NUMBER

RISER ELEVATION (Ft.) 657.0800

TANK CL BOTTOM ELEV (Ft.) - 615.0000

RISER TO TANK BOTTOM ELEV (Ft.) $4 \frac{1.0800}{492.96}$ (A)

\section{DETERMINING REFERENCE LEVEL:}

1/16 GASKET @50\% COMPRESSION (In.) + 0.0313

PVC FLANGE (OPTIONAL) (In.) + 1.0000

$1 / 8$ GASKET @ 50\% COMPRESSION (In.) + 0.0625

9.0000

BALL VALVE FLANGE TO FLANGE (In.) +

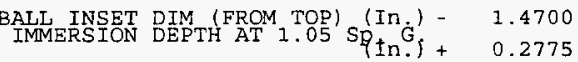

(F) USING BALL VALVE H-2-817634 PIN 48

(G)

REFERENCE LEVEL ( In $\quad 501.8612$

$(A+B+C+D+E-F+G)$

* IMMERSION DEPTH CALCULATION

GOVERNING EQUATION

$\mathrm{Fb}=$ BOUYANT FORCE $=$ SET POINT $=$

15.0000

GRAMS

$S g=$ SPECIFIC GRAVITY OF IIQUID $=1.0500$

$\mathrm{D}=$ DISPLACER DIAMETER =

2.0000 INCHES

$H=$

IMMERSION DEPTH (FROM EQUATION) =

0.7048 CENTIMETERS 


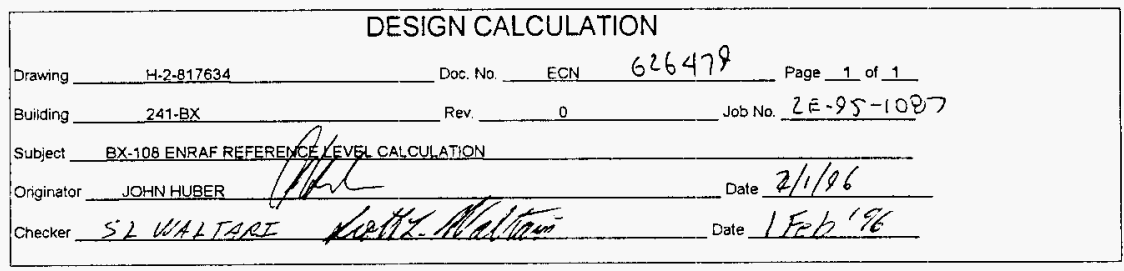

TANK NUMBER BX-108

BOTTOM OF TANK TO RISER DIMENSION

DRAWING NUMBER (H-2-37852)

RISER NUMBER (8)

RISER ELEVATION (Ft.) 656.0900

TANK CL BOTTOM ELEV (Ft.) - 615.0000

RISER TO TANK BOTTOM ELEV (Ft:) $4 \frac{1}{49} 9900$ (A)

DETERMINING REFERENCE LEVEL:

1/15 GASKET @50\% COMPRESSION (In.) + 0.0313 (B)

PVC FLANGE (OPTIONAL) (In.) +0.0000 (C)

$1 / 8$ GASKET @ 50\% COMPRESSION (In.) + 0.0000 (D)

BALL VALVE FLANGE TO FLANGE (In.) + 9.0000 (E)

BALL INSET DIM (FROM TOP) (In.) - 1.4700 (F) USING OLD BALL VALVE, INSET

IMMERSION DEPTH IN SOLIDS (In.) +0.0000 (G)

REFERENCE LEVEL (In:) $\quad 500.6413$

$(\mathrm{A}+\mathrm{B}+\mathrm{C}+\mathrm{D}+\mathrm{E}-\mathrm{F}+\mathrm{G})$ 


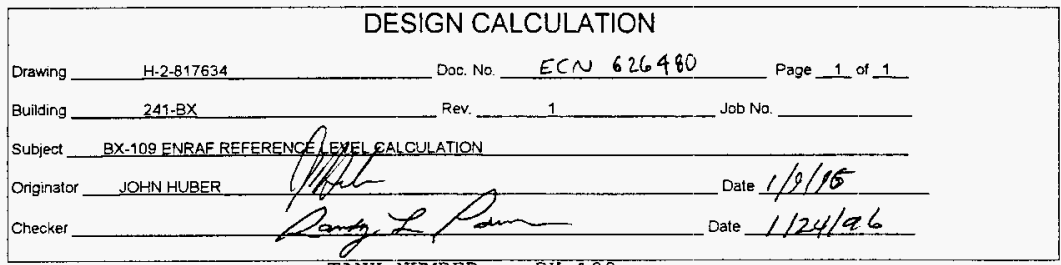

TANK NUMBER BX-109

BOTTOM OF TANK TO RISER DIMENSION

DRAWING NUMBER $(\mathrm{H}-2-37852)$

RISER NUMBER

RISER ELEVATION (Ft.) 655.0900

TANK CL BOTTOM ELEV (Ft.) - 614.0000

RISER TO TANK BOTTOM ELEV (Ft:) ${ }_{4}^{4} \frac{1}{493.090} \quad$ (A)

DETERMINING RERERENCE_LEVEL:

$1 / 16$ GSKT @ 50\% COMPRESSION (In.) + 0.0313 (B)

PVC FLANGE (OPTIONAL) (In.) +1.0000 (C)

$1 / 8$ GSKT @ 50\% COMPRESSION (In.) + 0.0625 (D)

BALL VALVE FLANGE TO FLANGE (In.) + 9.0000 (E)

BALI INSET DIM (FROM TOP) (In.) - 1.4700 (F)

IMMERSION DEPTH IN SOLIDS (In.) + 0 (G)

REFERENCE LEVEL ( $\left.\begin{array}{l}\text { Int. } \\ \text { Ft }\end{array}\right) \quad \begin{array}{r}51.7038 \\ 41.8086\end{array}$
$(A+B+C+D+E+F+G)$ 


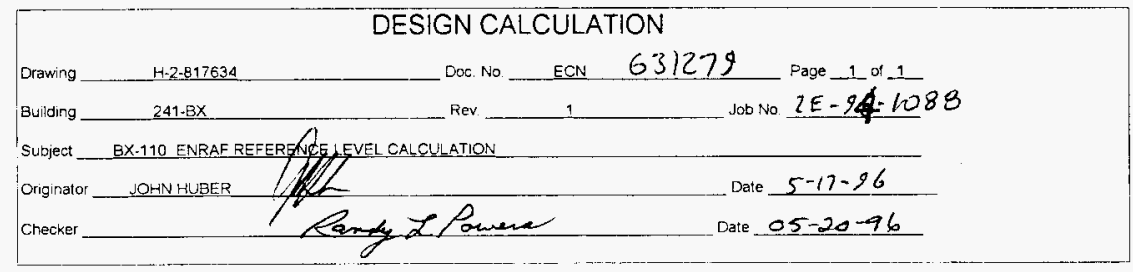

TANK NUMBER BX-110

BOTTOM OF TANK TO RISER DIMENSION

DRAWING NUMBER (H-2-37852)

RISER NUMBER (2)

RISER ELEVATION (Ft.) 657.5400

TANK CL BOTTOM ELEV (Ft.) - 516.0000

RISER TO TANK BOTTOM ELEV (FE.) $\begin{array}{rlll}41 & 15400 & \\ 493.48 & \text { (A) }\end{array}$

DETERMINING REFERENCE IEVEL:

1/16 GASKET (9) 50\% COMPRESSION (In.) +

$0.0313 \quad$ (B)

12" BLIND FLANGE - MODIFIED (In.) +

1. 2500

(C) (Assy 2 config.)

1/16 GASKET @ 50\% COMPRESSION (In.) +

0.0313

(D)

BALI VALVE FLANGE TO FLANGE (In.) +

BALL INSET DIM (FROM TOP) (In.) -

IMMERSION DEPTH SOLIDS (In.) +

9.0000

1. 4700

0.0000

(E)

(F)

REFERENCE LEVEL ( In: $\} \begin{array}{r}507.3225 \\ 42.2769\end{array}$

$(A+B+C+D+E-F+C)$

(G) 


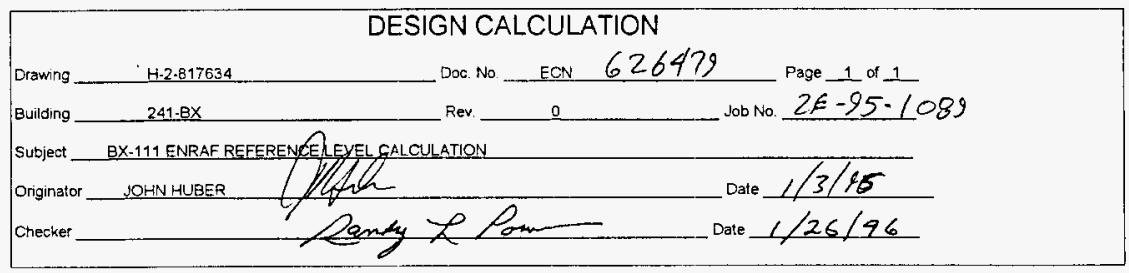

TANK NUMBER BX-111

BOTTOM OF TANK TO RISER DIMENSION

DRAWING NUMBER ( $\mathrm{H}-2-37852)$

RISER NUMBER (2)

RISER ELEVATION (Ft.) 656.5800

TANK CL BOTTOM ELEV (Ft.) - 615.0000

RISER TO TANK BOTTOM ELEV (Et:) $4 \frac{1}{4} 98.96 \quad$ (A)

DETERMINING REFERENCE LEVEL:

1/16 GASKET @ 50\% COMPRESSION (In.) + 0.0313 (B)

PVC FLANGE (OFTIONAL) (In.) + 0.0000 (C)

1/8 GASKET @ 50\% COMPRESSION (In.) + 0.0000 (D)

BALL VALVE FLANGE TO FLANGE (In.) + 9.0000 (E)

BALL INSET DIM (FROM TOP) (In.) - 1.4700 (F) USING OLO BALL VALVE, INSET

IMMERSION DEPTH IN SOLIDS (In.) + 0.0000 (G)

REFERENCE IEVEL (In:) $\begin{array}{r}506.5213 \\ 42.2101\end{array}$

$(\mathrm{A}+\mathrm{B}+\mathrm{C}+\mathrm{D}+\mathrm{B}-\mathrm{F}+\mathrm{Et}$ 


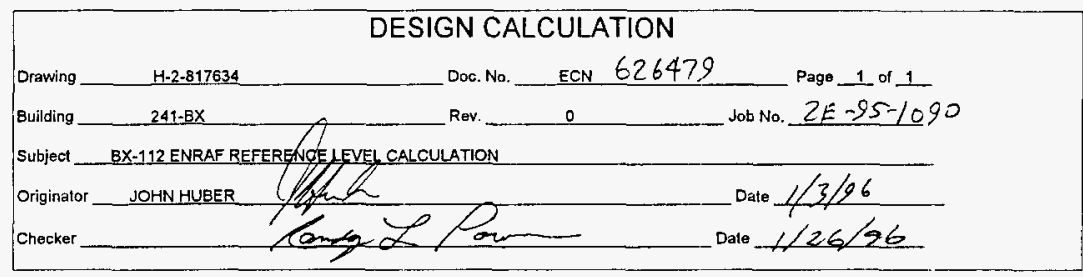

TANK NUMBER BX-112

BOTTOM OF TANK TO RISER DIMENSION

DRAWING NUMBER $(\mathrm{H}-2-37852)$

RISER NUMBER

(8)

RISER ELEVATION (Ft.) 655.1200

TANK CL BOTTOM ELEV (Ft.) - 614.0000

RISER TO TANK BOTTOM ELEV (FE.) 41.1200

(A)

DETERMINING REFERENCE ILVEL:

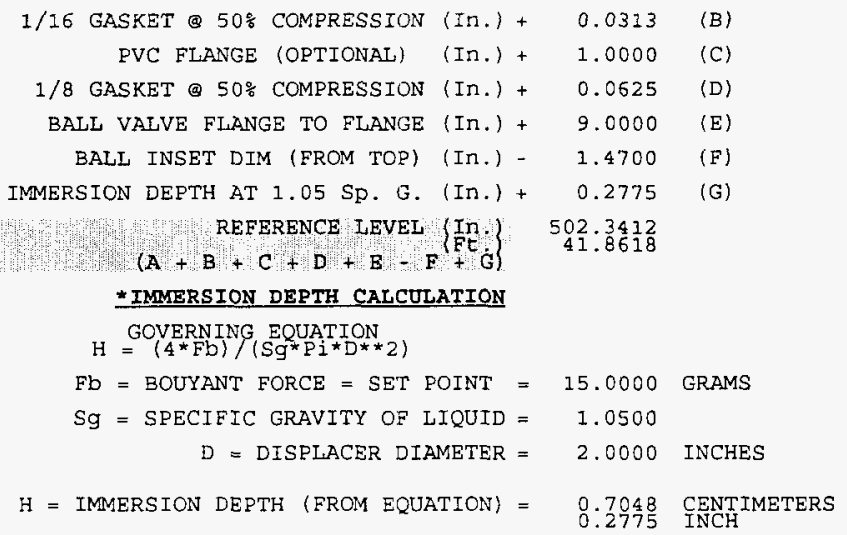


WHC-SD-WM-CN-078

REVISION $\mathrm{O}$

THIS PAGE RESERVED FOR BY -101 
THIS PAGE RESERVED FOR BY-102 


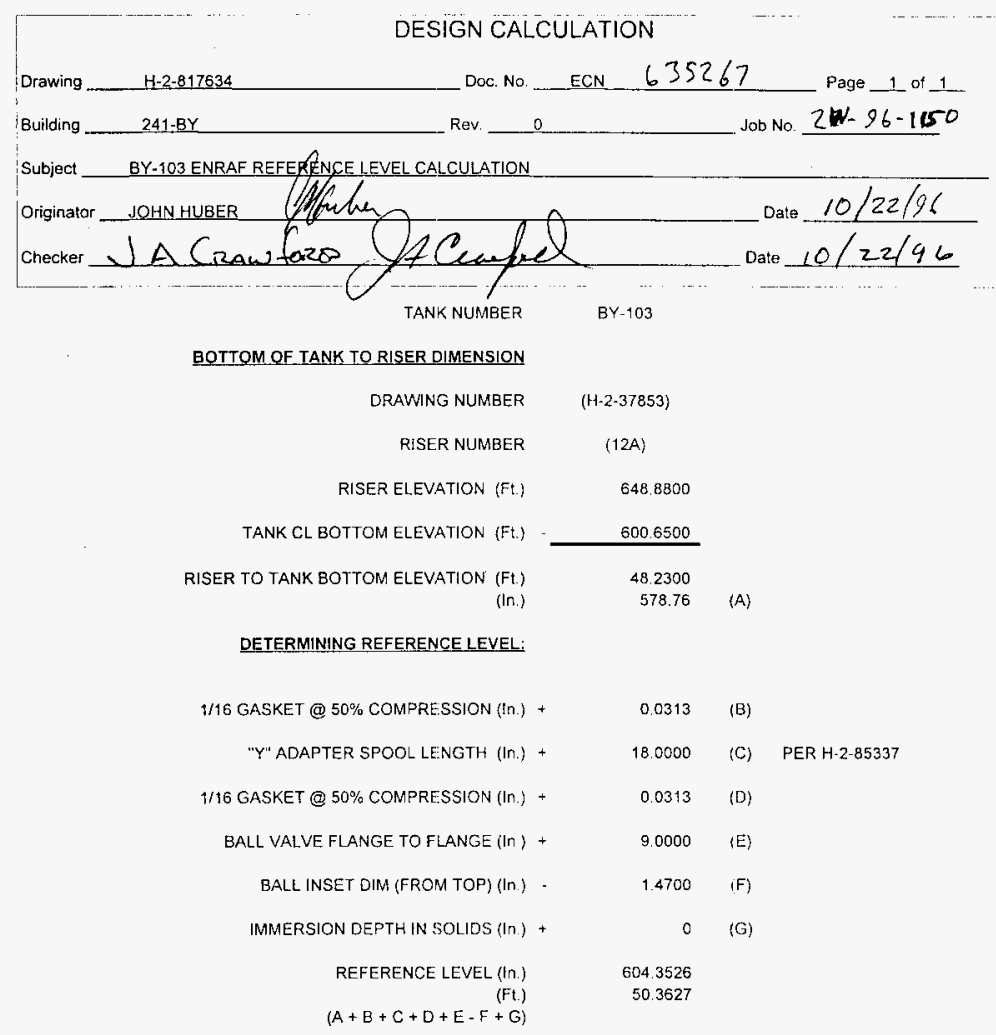


THIS PAGE RESERVED FOR BY-104 
WHC-SD-WM-CN-078

REVISION $O$

THIS PAGE RESERVED FOR BY-105 
THIS PAGE RESERVED FOR BY-106 
WHC-SD-WM-CN-078

REVISION 0

THIS PAGE RESERVED FOR BY-107 
THIS PAGE RESERVED FOR BY-108 
WHC-SD-WM-CN-078

REVISION 0

THIS PAGE RESERVED FOR BY-109 


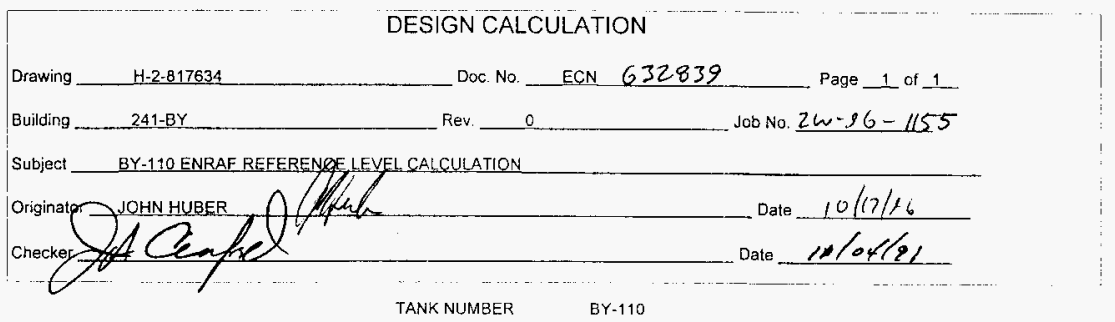

BOTTOM OF TANK TO RISER DIMENSSION

\begin{tabular}{|c|c|c|}
\hline DRAWING NUMBER & $(\mathrm{H}-2-37853)$ & \\
\hline RISER NUMBER & (4) & \\
\hline RISER ELEVATION (FU.) & 649.8500 & \\
\hline TANK CL BOTTOM ELEVATION (FL.) & 602.6500 & \\
\hline $\begin{array}{r}\text { RISER TO TANK BOTTOM ELEVATION ( } \mathrm{Ft.}) \\
(\mathrm{Im})\end{array}$ & $\begin{array}{r}47.2000 \\
566.4\end{array}$ & (A) \\
\hline \multicolumn{3}{|l|}{ DETERMINING REFERENCELEVEL: } \\
\hline 1/16 GASKET @ 50\% COMPRESSION (In.) + & 0.0313 & (B) \\
\hline PVC FLANGE (OPTIONAL) (In.) + & 0.0000 & (C) \\
\hline 1/8 GASKET@50\% COMPRESSION $(\mathrm{In})+$. & 0.0000 & (D) \\
\hline BALL VALVE FLANGE TO FLANGE $(\ln )+$ & 9.0000 & (E) \\
\hline BALL INSET OIM (FROM TOP) (II ) - & 1.4700 & $\{\mathrm{~F}\}$ \\
\hline IMMERSION DEPTH IN SOLIDS $(I n)+$ & 0 & (G) \\
\hline $\begin{array}{r}\text { REFERENCE LEVEL (In }) \\
(\mathrm{Ft}) \\
(\mathrm{A}+\mathrm{B}+\mathrm{C}+\mathrm{D}+\mathrm{E}-\mathrm{F}+\mathrm{G})\end{array}$ & $\begin{array}{r}573.9613 \\
47.8301\end{array}$ & \\
\hline
\end{tabular}




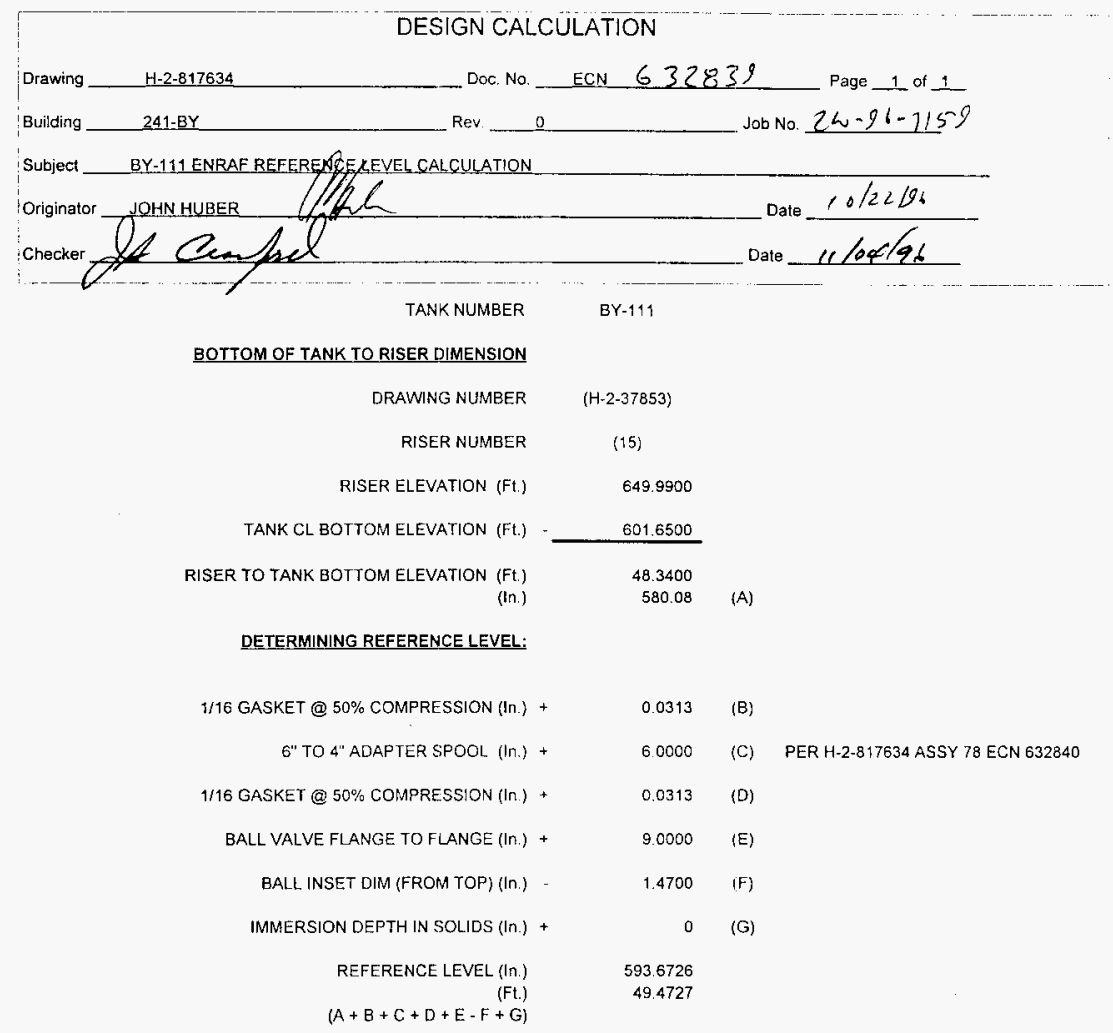


THIS PAGE RESERVED FOR BY-112 
THIS PAGE RESERVED FOR $\mathrm{C}-101$ 


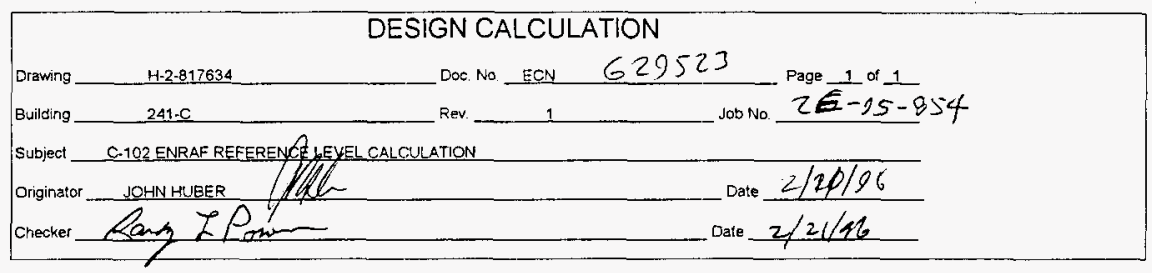

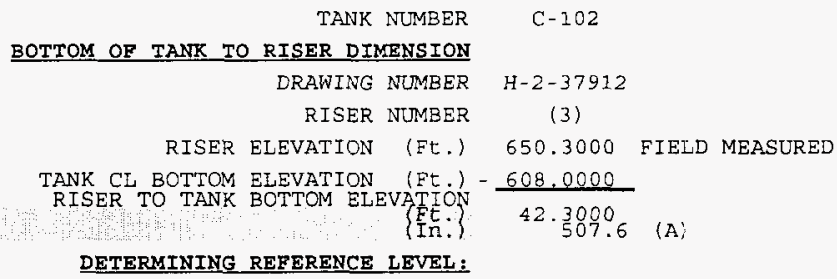

$1 / 16$ GASKET @ 50\% COMPRESSION (In.) + 0.0313 (B)

PVC FLANGE (OPTIONAL) (In.) + 0.0000 . (C)

$1 / 8$ GASKET@50\% COMPRESSION $(\mathrm{In})+$.0.0000 (D)

BALL VALVE FLANGE TO FLANGE (In.) + 9.0000 (E)

BALL INSET DIM (FROM TOP) (In.) - 1.4700 (F) FIELD MEASURED

IMMERSION DEPTH IN SOLIDS (In.) + 0 (G)

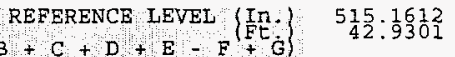


TANK NUMBER C-103

\section{DETERMINING BOTTOM OF TANK TO RISER}

\section{DRAWING NUMBER (H-2-37912)}

RISER NUMEER (8)

RISER ELEVATION (Ft.) 645.6700

TANK INSIDE BOTTOM ELEVATION (Ft.) - N/A

TANK SIDE-BOTTOM ELEVATION (Ft.) - 608.0000

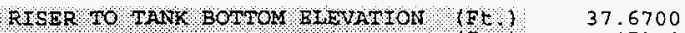

110) $\quad 452.04$

DETERMINING REFERENCE LEVEL:

1/16 GASKET @ $50 \%$ COMPRESSION (In.) + 0.0313 (B)

PVC FLANGE (OPTIONAL) (In.) +1.0000 (C)

1/8 GASKET @ 908 COMPRESSION (In.) + 0.0625 (D)

BALL VALVE FIANGE TO FLANGE (In.) + 9.0000 (E)

BAII INSET DIM (FROM TOP) (In.) - 1.2100 (F)

* IMMERSiON DEPTH AT $1.05 \mathrm{sp} . \mathrm{G}$. (In.) + 0.8574 (G)

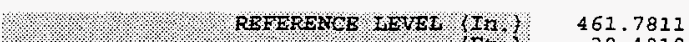

$1.1 .10 \%$ ) 38.4818

* IQMERSION DEPTH CALCDLATION

GOVERNING EQUATION

$H=(4 * F b) /(S g * P i * D * \star 2)$

$\mathrm{Fb}=$ BOUYANT FORCE $=$ SET POINT $=15.0000$ GRAMS

$S g=$ SPECIFIC GRAVITY OF LIQUID $=0.8700$

$$
D=\text { DISPLACER DIAMETER }=1.2500 \text { INCHES }
$$

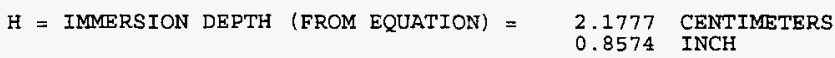


WHC-SD-WM-CN-078

REVISION 0

THIS PAGE RESERVED FOR $\mathrm{C}-104$ 


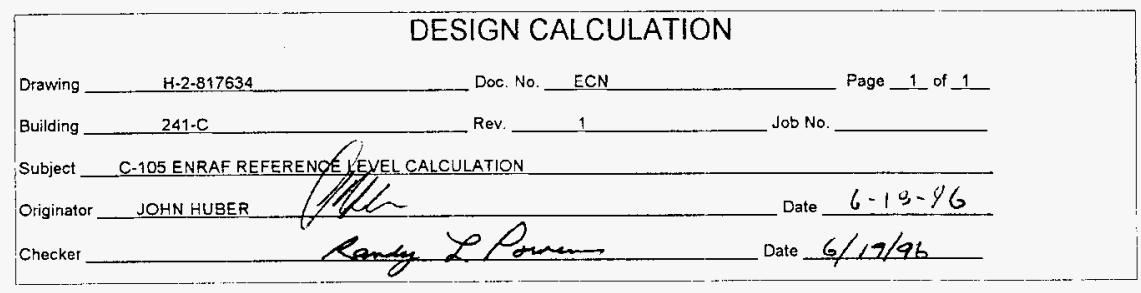

$$
\text { TANK NUMBER C- } 105
$$

BOTTOM OE TANK TO RISER DIMENSION

DRAWING NUMBER (H-2-37912)

RISER NUMPER (8)

$$
\text { RISER ELEVATION (FE.) } 646.7400
$$

TANK INSIDE BOTTOM ELEVATION (FE.) - N/A

TANK SIDE-BOTTOM ELEVATION (FE.) - 609.0000

RISER TO TANK BOTTOM ELEVATION (Ft.) $\begin{array}{rll}37.7400 & \\ 452.88 & \text { (A) }\end{array}$

DETERMINING REFERENCE LEVEL:

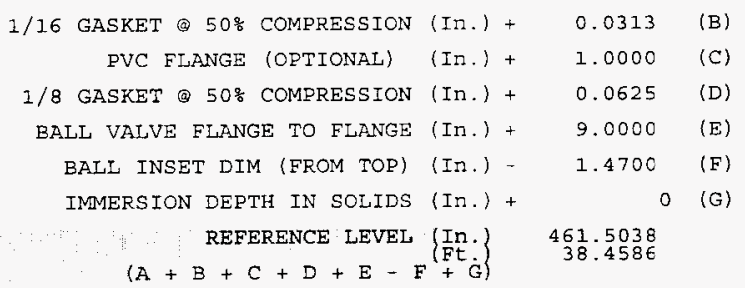




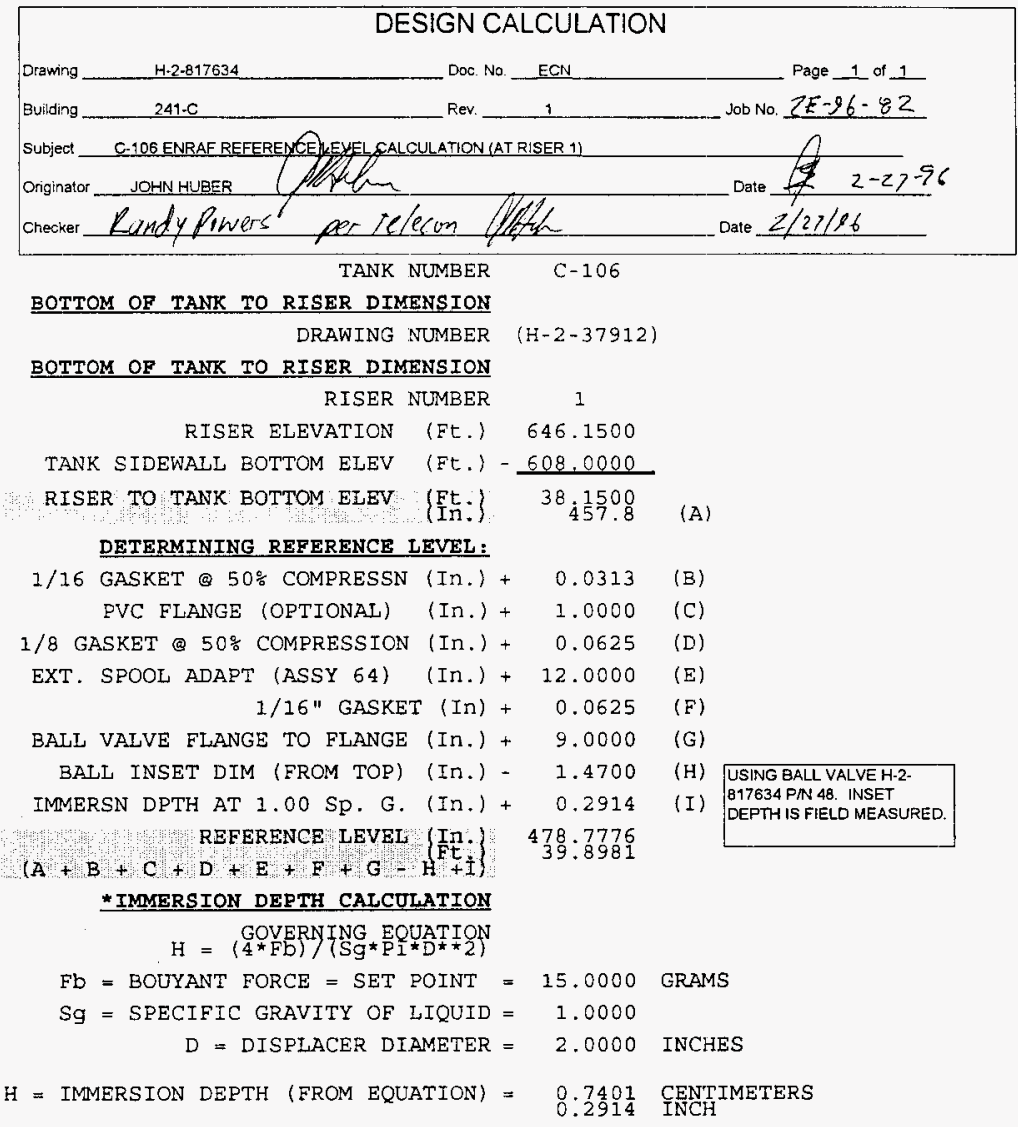


TANK NUMBER

$C-107$

BOTTOY OF TANK TO RISER DIMENSION

DRAWING NUMBER

RISER NUMBER

RISER ELEVATION (Ft.)

TANK INSIDE BOTTOM ELEVATION (Ft.) -

TANK SIDE-BOTTOM ELEVATION (Ft.) -

PISER TO TAN 30 T TOH ELFVATION (Pt)

(1n.

(8)
(H-2-37912)

648.1800

$N / A$

610.0000

38.1800 458.16

(A)

DETERMINING REFERENCE LEVEL:

$1 / 16$ GASKET @ 508 COMPRESSION (In.) + 0.0313 (B)

PVC FLANGE (OPTIONAL) (In.) + 1.0000 (c)

$1 / 8$ GASKET @ $50 \%$ COMPRESSION (In.) +0.0625 (D)

BALL VALVE FLANGE TO FLANGE (In.) + 9.0000 (E)

BALL INSET DIM (FROM TOP) (In.) - 1.2100 (F)

IMMERSION DEPTH IN SOLIDS (In.) +

REPERENCB TEVEL (IN

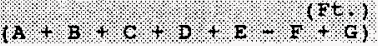

467.0437

38.9203

0 (G)

PARAMETERS

$\mathrm{TT}=$

$\mathrm{UR}=$

$\mathrm{MH}=$

$\mathrm{HH}=$

$\mathrm{HA}=$

$\mathrm{RL}=$

$\mathrm{AN}=$ $\mathrm{AM}=$ $\mathrm{TI}=$ $M L=$ LA $=$ $\mathrm{LL}=$ WT $=$ 
WHC-SD-WM-CN-078

REVISION 0

THIS PAGE RESERVED FOR $\mathrm{C}-108$ 
WHC-SD-WM-CN-078

REVISION 0

THIS PAGE RESERVED FOR C-109 
WHC-SD-WM-CN-078

REVISION 0

THIS PAGE RESERVED FOR C-110

A-88 
THIS PAGE RESERVED FOR C-111 


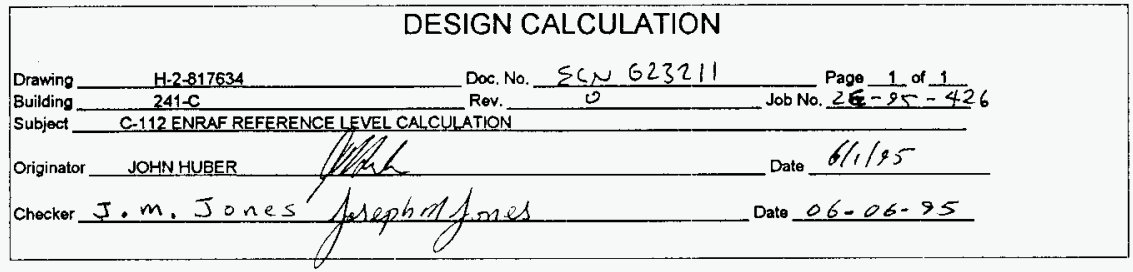

$$
\begin{array}{rrc}
\text { TANK NUMBER } & \text { C-112 } \\
\text { BOTTOM OF TANK TO RISER } & \\
\text { DRAWING NUMBER } & (\mathrm{H}-2-37912) \\
\text { RISER NUMBER } & (5) \\
\text { TISER ELEVATION (Ft.) } & 645.7000 \\
\text { TANK INSIDE BOTTOM ELEVATION - } & \text { N/A }
\end{array}
$$

TANK SIDE-BOTTOM ELEVATION - 608.0000

RISER TO TANX BOTTOM ELEVATION 37.7000

R.P.

DETERMINING REFERENCE LEVEL:

$1 / 16$ GASKET C 508 COMPRESSION + PVC FLANGE (OPTIONAL) (In.) +

$1 / 8$ GASKET \& 508 COMPRESSION + BALL VALVE FLANGE TO FLANGE + BALI, INSET DIM (FROM TOP) IMMERSION DEPTH IN SOLIDS +

0.0313

0.0000

0.0000

9.0000

1.2100

0

0 (G)
(B)

(C) REPLACING MANUAL TAPE; NO RISER LINER

(D)

(E)

(F)

USING OLD BALL VALVE, H-2-817634, P/N 20

MOST RECENT PHOTOS INDICATE SOLIDS/SLUDGE BELOW PLUMMET - NO IMMERSION DEPTH 
WHC-SD-WM-CN-078 REVISION 0

THIS PAGE RESERVED FOR C-201

A-91 
WHC-SD-WM-CN-078 REVISION 0

THIS PAGE RESERVED FOR C-202 
WHC-SD-WM-CN-078

REVISION 0

THIS PAGE RESERVED FOR C-203

A-93 
THIS PAGE RESERVED FOR C-204 


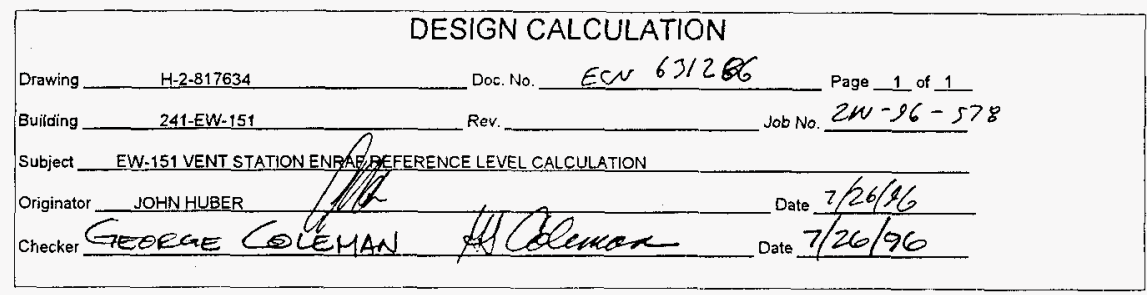

TANK NUMBER

BOTTOM OF TANK TO RISER DIMENSION

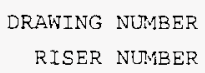

FINISHED FLOOR ELEV. (Ft.)

TANK OUTSIDE BOTTOM ELEVATION (Ft.) -

$\begin{array}{ll}\text { H-2-43148 } & \text { (Ft.) + } \\ \mathrm{H}-2-43148 & \text { (Ft.) + } \\ \mathrm{H}-2-43148 & \text { (Ft.) + } \\ \mathrm{H}-2-43148 & \text { (Ft.) + } \\ \mathrm{H}-2-43148 & \text { (Ft.) + }\end{array}$

TANK WALI THICKNESS (FE.) -

3" BLIND ELANGE THICKNESS (Ft.) -

RISER TO TANK BOTTOM ELEVATION

(Ft:)

DETERMINING REFERENCE LEVEL:
$E W-151$

$$
\begin{gathered}
H-2-43148 \\
N / A
\end{gathered}
$$

$$
\begin{array}{r}
745.0000 \\
745.3900 \\
8.3300 \\
1.5000 \\
3.6700 \\
2.0000 \\
1.5000 \\
0.0313 \\
0.0833 \\
16.4954 \\
197.945
\end{array}
$$

\begin{tabular}{|l|}
\hline$+\cdot 2-43155$ \\
\hline$H \cdot 2-43155$ \\
\hline
\end{tabular}

3/8" THICK TANK WALLL PER H-2-43146 $3^{n} 150$ \# BLIND FLANGE IS $1^{*}$ THK

(A)
1/16 GASKET @ 50\% COMPRESSION (In.) +
0.0313
(B)
3" TO 4" ADAPTER FLANGE (In.) +
1. 5000
(C)
1/16 GASKET 50\% COMPRESSION (In.) +
0.0313
(D)
9.0000
(E)
1.4700
(F)
0.2775
(G)
$\left(\mathrm{A}+\mathrm{B}+\mathrm{C}+\mathrm{D}+\mathrm{E}-\mathrm{F}^{(\mathrm{Ft}}+\mathrm{G}\right)$
$207 \cdot 3750$

\section{* IMMERSION DEPTH CALCULATION}
GOVERNING EQUATION
$H=(4 * F b) /\left(S g^{\star} P i * D^{\star \star} 2\right)$
$\mathrm{Fb}=$ BOUYANT FORCE $=$ SET FOINT $=$
$\mathrm{Sg}=$ SPECIFIC GRAVITY OF LIQUID $=$
D = DISPLACER DIAMETER $=$
$\mathrm{H}=$ IMMERSION DEPTH (FROM EQUATZON) =
15.0000 GRAMS
1. 0500
2.0000 INCHES
$\begin{array}{ll}0.7048 & \text { CENTIMETERS } \\ 0.2775 & \text { INCH }\end{array}$ 
TANK NUMBER

s-101

BOTIOM OF TAHR TO RISER DIMENSION

$$
\text { DRAWING NUMBER }
$$

$$
\text { RISER NUMBER }
$$

$$
\text { RISER ELEVATION (Ft.) }
$$

TANK INSID

TANK SIDE-BOTTOM ELEVATION (Ft.) -

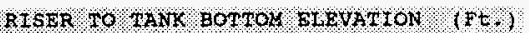

In

DETERMINING REFERENCE LEVEL:

$1 / 16$ GASKET @ 508 COMPRESSION (In.) + PVC FLANGE (OPTIONAL) (In.) +

$1 / 8$ GASKET @ 50\% COMPRESSION (In.) +

BALL VALVE FLANGE TO ELANGE (In.) +

BALL INSET DIM (FROM TOP) (In.) -

IMMERSION DEPTH ON SOLIDS (In.) +

REEERENCO LEYEL In I

$101001+10)$ $(\mathrm{A}+\mathrm{B}+\mathrm{C}+\mathrm{p}+\mathrm{E}+\mathrm{p}+\mathrm{+} \mathrm{Q})$
665.9400

(H-2-3738I)

620.4300

$N / A$

45.5100

546.12

(A)

0.0313

(B)

1.0000

(C)

0.0625

(D)

9.0000

(E)

1.2100

0

(G)
PARAMETERS

$T T=$

$\mathrm{UR}=$

$\mathrm{MH}=$

$\mathrm{HH}=$

$\mathrm{HA}=$

$\mathrm{RL}=$

AN $=$

$A M=$

$\mathrm{S} 1=$

$52=$

$53=$

$T I=$

$M I=$

$L A=$

$\mathrm{LI}=$

WT $=$ 


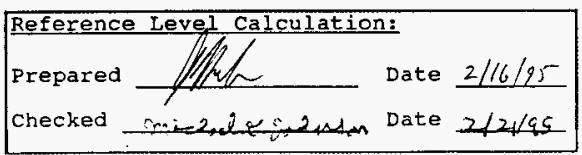

TANK NUMBER

$s-102$

BOTIOY OF TANK TO RISER DIMENSION

$$
\begin{aligned}
& \text { DRAWING NUMBER } \\
& \text { RISER NUMBER }
\end{aligned}
$$$$
(\mathrm{H}-2-37381)
$$

$$
\text { RISER ELEVATION (Ft.) }
$$

665.0500

TANK INSIDE BOTTOM ELEVATION (Ft.) - 619.4300

TANK SIDE-BOTTOM ELEVATION (Ft.) $\mathrm{N} / \mathrm{A}$

\section{. RTBEF TO TAMT BOTTOU ELEVATIOH (Pt.)}

DETERMINING REFERENCE LEVEL:

$1 / 16$ GASKET @ $50 \%$ COMPRESSION (In.) PVC FLANGE (OPTIONAL) (In.) +

$1 / 8$ GASKET \& 508 COMPRESSION (In.) + Ball VALVE FLANGE TO FLANGE (In,) + BALI INSET DIM (FROM TOP) (In.) IMMERSION DEPTH ON SOLIDS (In.) +

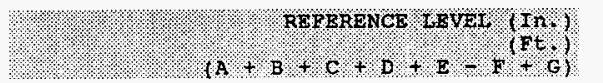

0.0313

1.0000

(C)

0.0625

9.0000

1.4700

\section{PARAMETERS}

$\mathrm{TT}=580.66$

$\mathrm{UR}=580.66$

$\mathrm{MH}=575.06$

$\mathrm{HH}=568.06$

$\mathrm{HA}=562.06$

$\mathrm{RL}=556.06$

$A N=N / A$

$A M=N / A$

$T I=. S 102$

$M L=1.00$

$\mathrm{LA}=12.00$

$L L=6.00$

$\mathrm{WT}=\mathrm{EDE}$ 
TANK NUMBER S-103

BOTTOM OF TANK TO RISER DIMENSION

TANK INSIDE BOTTOM ELEVATION (Ft.)

TANK SIDE-BOTTOM ELEVATION (Ft.) -

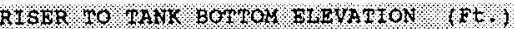

$$
\begin{array}{r}
\text { DRAWING NUMBER } \\
\text { RISER NUMBER }
\end{array}
$$

$$
\text { RISER ELEVATION (Ft.) }
$$

664.0600

$1 \mathrm{n}+\mathrm{l}$

$(\mathrm{H}-2-37381)$

\section{(3)}

618.4300

$N / A$

45.6300

547.56

DETERMINING REFERENCE LEVEL:

\section{PARAMETERS}

$\mathrm{TT}=580.90$

$\mathrm{UR}=580.90$

$\mathrm{MH}=575.30$

$\mathrm{HH}=568.30$

$\mathrm{HA}=562.30$

$R L=556.72$

$\mathrm{AN}=129.80$

$A M=79.80$

$\mathrm{TI}=$

$M L=$

$L A=$

$\mathrm{LI}=$

WT $=$

(A)

$1 / 16$ G

PVC FLANGE (OPTIONAL) (In.) + 1.0000

$1 / 8$ GASKET @ 508 COMPRESSION (In.) +

0.0625

(D)

BALL VALVE FLANGE TO FLANGE (In.) +

9.0000

BALI INSET DIM (FROM TOP) (In.) -

1.2100

IMMERSION DEPTH AT 1.05 sp. G. (In.) + 0.2774923

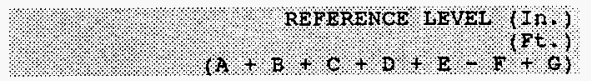

556.7212

46.3934

\section{* IMMERSION DEPTH CALCULATION}

$$
\begin{aligned}
& \text { GOVERNING EQUATION } \\
& \mathrm{H}=(4 * \mathrm{Fb}) /(\mathrm{Sg} * \mathrm{Pi} \star \mathrm{D} \star \star 2) \\
& \mathrm{Fb}=\text { BOUYANT FORCE }=\text { SET POINT }=15.0000 \text { GRAMS } \\
& S g=\text { SPECIFIC GRAVITY OF LIQUID }=1.0500 \\
& D=\text { DISPLACER DIAMETER }=2.0000 \text { INCHES } \\
& \mathrm{H}=\text { IMMERSION DEPTH (FRON EQUATION) = } \begin{array}{ll}
0.7048 & \text { CENTIMETERS } \\
0.2775 & \text { INCH }
\end{array}
\end{aligned}
$$


WHC-SD-WM-CN-078

REVISION 0

THIS PAGE RESERVED FOR S--104 

(1) Drawing $\mathrm{H}-2-817634$
(4) Building $241-5$
(2) Doc. No.
(3) Page $1 \ldots$ of 1
(7) Subject $s-105$ Enraf Reference Level Caleulations
(8) Originator John Huber funh Date $4-11+9$,
(9) Checker minele $4 . g$. Ruran Date $4 / 24 / 45$

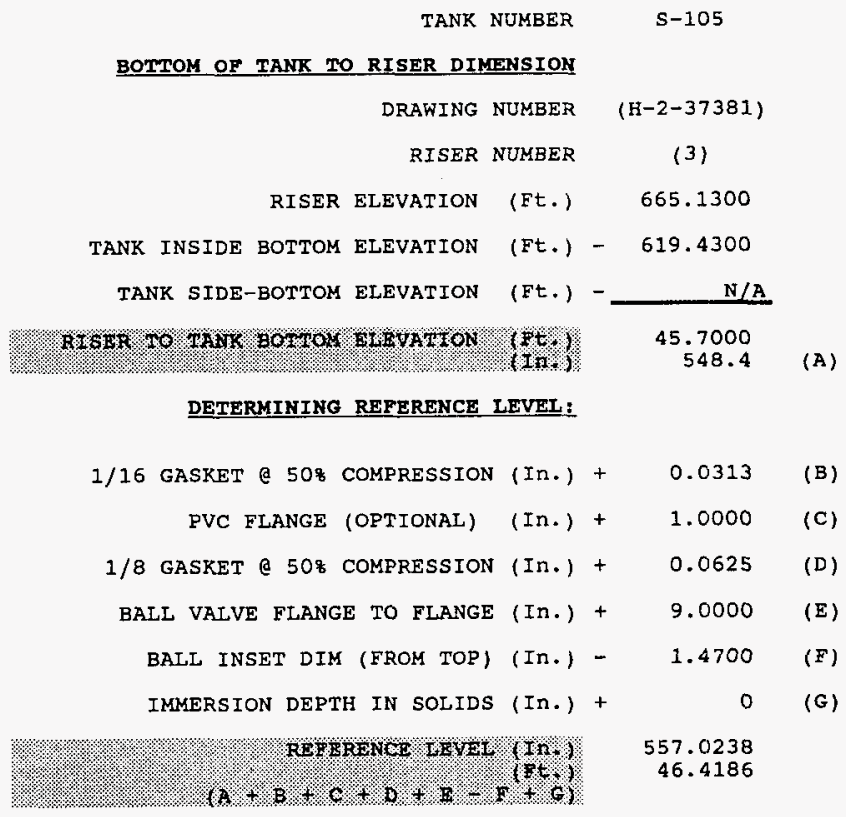


TANK NUMBER

$S-106$

BOTTOM OF TANR TO RISER DIMENSION

$$
\begin{array}{r}
\text { DRAWING NUMBER } \\
\text { RISER NUMBER }
\end{array}
$$

$$
\text { RISER ELEVATION (Ft.) }
$$

TANK INSIDE BOTTOM ELEVATION

(Ft.)

TANK SIDE-BOTTOM ELEVATION (Ft.) -

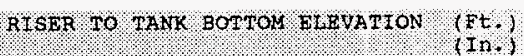

DETERMINING REFERENCE LEVEL:
664.0500

618.4300

( $\mathrm{H}-2-37381)$

$N / A$

45.6200 547.44

\section{PARAMETERS}

$\mathrm{TT}=581.25$

$\mathrm{UR}=581.25$

$\mathrm{MH}=575.65$

$\mathrm{HH}=568.65$

$\mathrm{HA}=562.65$

$\mathrm{RL}=556.60$

$A N=201.80$

$\mathrm{AM}=151.80$

TI $=. S 106$

$\mathrm{MI}=1.00$

$L A=12.00$

$L I=6.00$

(A)

$$
\begin{array}{r}
1 / 16 \text { GASKET \& } 508 \text { COMPRESSION (In.) + } \\
\text { PVC FLANGE (OPTIONAI) (In.) + } 0.0313 \text { (B) } \\
1 / 8 \text { GASKET \& } 508 \text { COMPRESSION (In.) + } 0.0000 \text { (C) } \\
\text { BALL VALVE FLANGE TO FLANGE (In.) + } 9.0000 \text { (E) } \\
\text { BALL INSET DIM (FROM TOP) (In.) - } 1.2100 \text { (F) } \\
\text { IMMERSION DEPTH AT } 1.05 \text { SP. G. (In.) + }+0.2774923 \text { (G) }
\end{array}
$$

556.6012

46.3834
REPBENCP $1 \mathrm{EVEV} / \mathrm{In}$

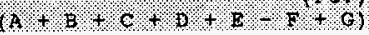

* IMMERSION DEPTH CALCULATION

GOVERNING EQUATION

$H=(4 \star F b) /(S g \star P i \star D \star \star 2)$

$\mathrm{Fb}=$ BOUYANT FORCE = SET POINT =

$\mathrm{Sg}=$ SPECIFIC GRAVITY OF LIQUID =

$D=$ DISPLACER DIAMETER =

$H=$ IMMERSION DEPTH (FROM EQUATION) =

\author{
15.0000 GRAMS \\ 1.0500 \\ 2.0000 INCHES \\ 0.7048 CENTIMETERS \\ 0.2775 INCH
}


TANK NUMBER S-107

BOTTOM OF TANR TO RISER DIMENSION

RISER ELEVATION (Ft.)

TANK INSIDE BOTTOM ELEVATION (Ft.) - 620.4300

TANK SIDE-BOTTOM ELEVATION (Ft.) -

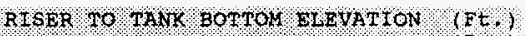

Int)

666.0300

45.6000

547.2

$$
\begin{array}{r}
\text { DRAWING NUMBER } \\
\text { RISER NUMBER }
\end{array}
$$

$(\mathrm{H}-2-37381)$

(A)

0.0313

(B)

PVC FLANGE (OPTIONAL) (In.) + 1.0000

(C)

$1 / 8$ GASKET @ 508 COMPRESSION (In.) + 0.0625

9.0000

BALL VALVE FLANGE TO FLANGE ( $\mathrm{n}$, ) +

1.2 .100

BALL INSET DIM (FROM TOP) (In.) -

IMHERSION DEPTH AT $1.05 \mathrm{sp}$. G. (In.)

$R E B E R E N O B$ LEVAY (In,

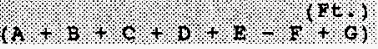

0.2774923

556.3612

46.3634

\section{¿ IMMERS ION DEPTH CALCULATION}

GOVERNING EQUATION

$H=(4 * F b) /(S g * P i * D * \star 2)$

$\mathrm{Fb}=$ BOUYANT FORCE = SET POINT =

15.0000

GRAMS

$S g=$ SPECIFIC GRAVITY OF LIQUID =

1.0500

D = DISPLACER DIAMETER =

2.0000

INCHES

$H=$ IMMERSION DEPTH (FROM EQUATION) =

0.7048

0.2775

CENTIMETERS

INCH

\section{PARAMETERS}

$\mathrm{TT}=581.10$

$\mathrm{UR}=581.10$

$\mathrm{MH}=575.50$

$\mathrm{HH}=568.50$

$\mathrm{HA}=562.50$

$\mathrm{RI}=556.36$

$\mathrm{AN}=169.20$

$A M=119.20$

$\mathrm{TI}=$

MI, =

$\mathrm{LA}=$

LI =

$\mathrm{WT}=$ 
(1) Drawing $14-2-817634$

(4) Building $241-5$

(2) Doc. No.

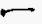

(5) Rev

0

(3) Page of 1

(7) Subject $5-108$

eeterence

(8) Originator

John tuber

(9) Checker miese \& o

anter (6) Job No. Calcularions Date $4 / 1 /-95$ Date $4 / 25 / 45$

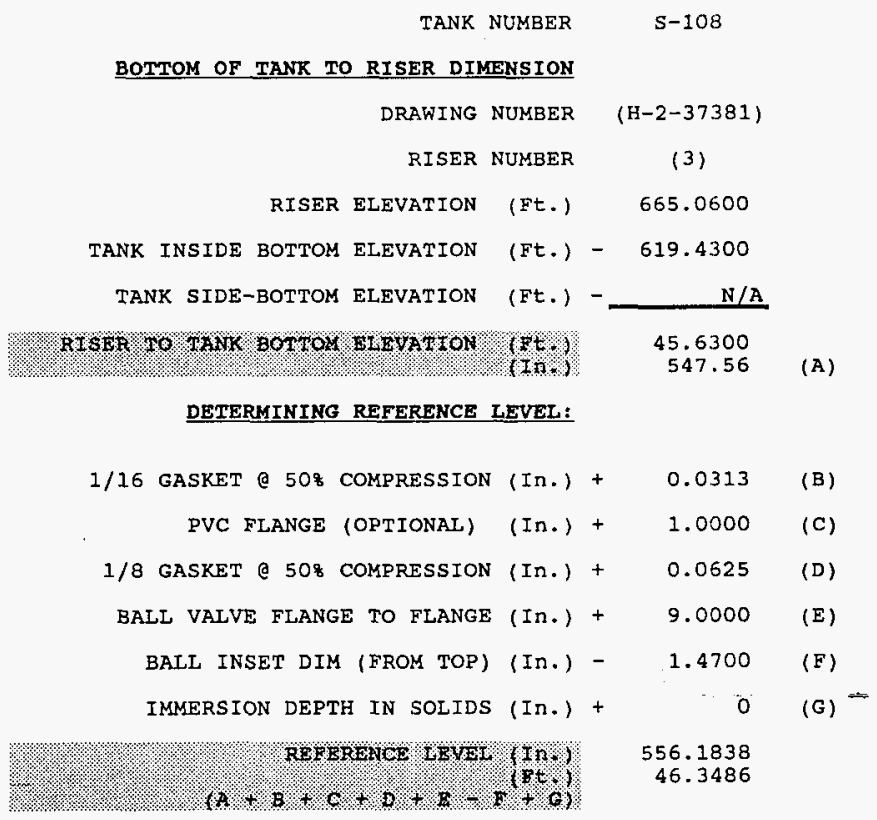



(1) Drawing $1+-2-817634$
(2) Doc. No
(3) Page 1 of 1
(4) Building $24 /-5$
(5) Rev.
0
$-$
(6) Job No
(7) Subject $5-109$ Enraf Retegence Level Calculanions
(8) Originator John Huber t/phe Date $4-11-95$
(9) Checker misent is 8 Date $4 / 25 / 96$

(10)

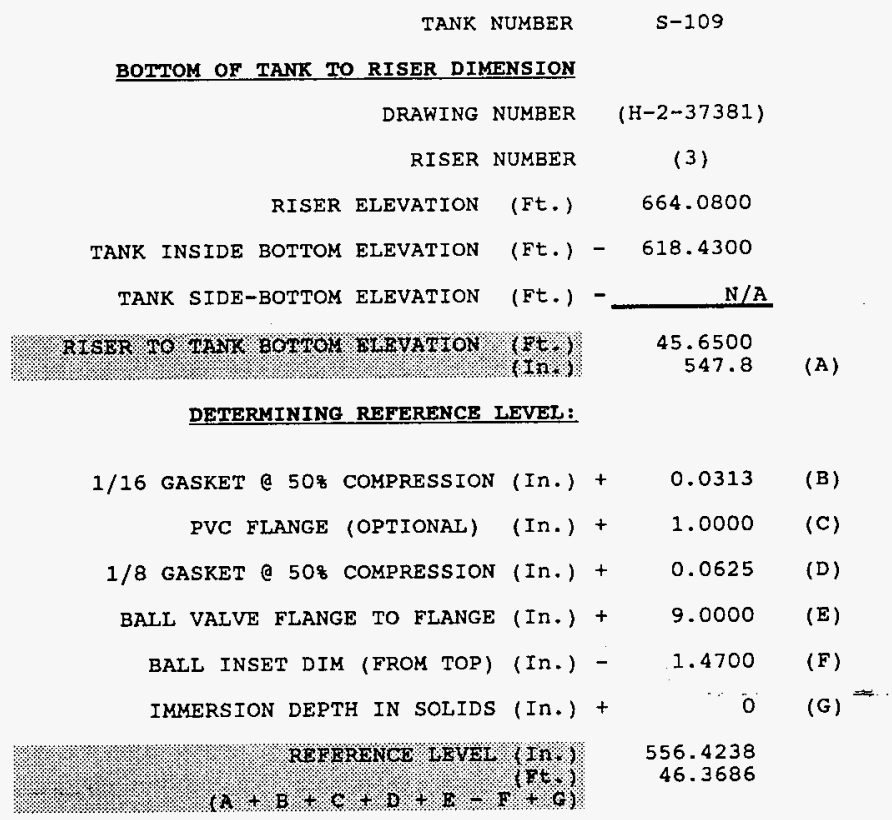




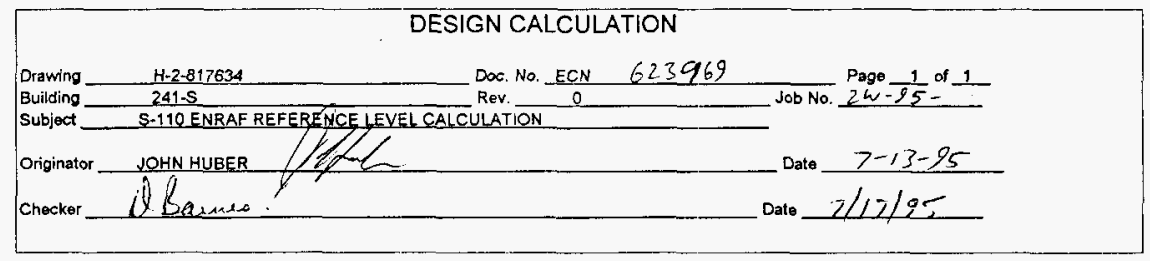

\begin{tabular}{|c|c|c|c|}
\hline TANK NUMBER & $s-110$ & & \\
\hline BOTTOM OF TANK TO RISER & & & \\
\hline DRAWING NUMBER & $(\mathrm{H}-2-37381)$ & & \\
\hline RISER NUMBER & (3) & & \\
\hline RISER ELEVATION (Ft.) & 666.3400 & & \\
\hline TANK INSIDE BOTTOM ELEVATION & -620.4300 & & \\
\hline TANK SIDE-BOTTOM ELEVATION & N/A & & \\
\hline MISER TO TANR BOTTOM ELEVATION & $\begin{array}{r}45.9100 \\
550.92\end{array}$ & (A) & \\
\hline \multicolumn{4}{|l|}{ DETERMINING REFEREKCE LEVEL: } \\
\hline $1 / 16$ GASKET \& 508 COMPRESSION & 0.0313 & (B) & \\
\hline PVC FLANGE (OPTIONAI) (In.) & 1.0000 & (C) & \\
\hline 1/8 GASKET \& 50\% COMPRESSION & 0.0625 & (D) & \\
\hline BALL VALVE FLANGE TO FLANGE & 9.0000 & (E) & \\
\hline BALL INSET DIM (FROM TOP) (In.) & 1.4700 & (F) & $\begin{array}{l}\text { NEW BALL VALVE, H-2- } \\
817634, \text { P/N } 48\end{array}$ \\
\hline IMMERSION DEPTH IN SOLIDS (In.) & 0 & (G) & \\
\hline 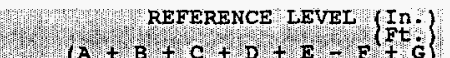 & $\begin{array}{r}559.5438 \\
46.6286\end{array}$ & & \\
\hline
\end{tabular}


TANK NUMBER

$5-111$

BOTTOY OF TANK TO RISER DIMENSION

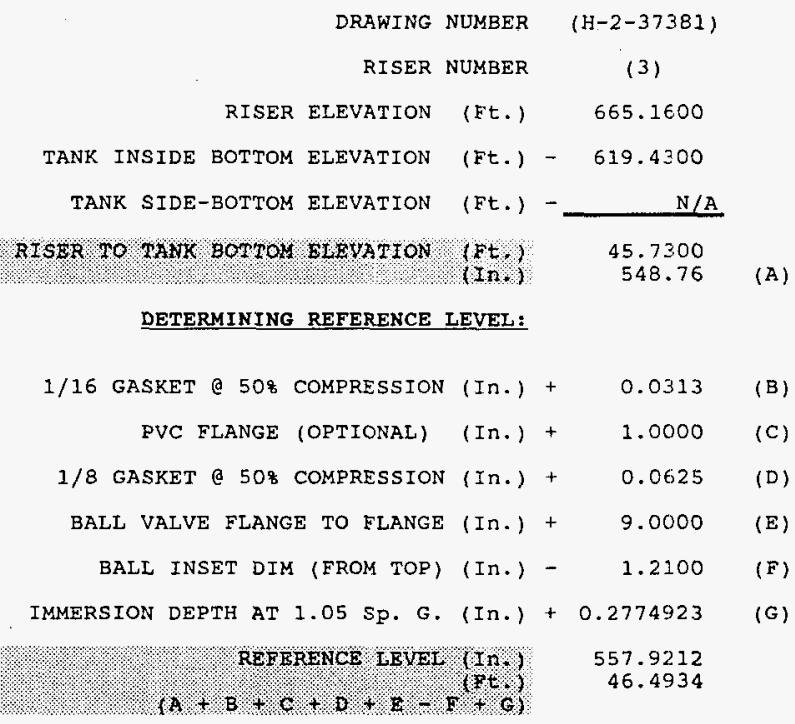

\section{PARAMETERS}

$T T=582.57$

$\mathrm{UR}=582.57$

$\mathrm{MH}=576.97$

$\mathrm{HH}=569.97$

$\mathrm{HA}=563.97$

$\mathrm{RL}=557.92$

$\mathrm{AN}=227.60$

$\mathrm{AM}=177.60$

$\mathrm{TI}=\ldots \mathrm{S} 111$

$\mathrm{ML}=1.00$

$\mathrm{LA}=12.00$

$\mathrm{LI}=6.00$

$\mathrm{WT}=\mathrm{EDE}$

\footnotetext{
* IMMERSION DEPTH CALCULATION

GOVERNING EQUATION

$\mathrm{H}=(4 * \mathrm{Fb}) /(\mathrm{Sg} * \mathrm{Pi} * \mathrm{D} * 2)$

$\mathrm{Fb}=$ BOUYANT FORCE $=$ SET POINT $=15.0000$ GRAMS

$S g=$ SPECIFIC GRAVITY OF LIQUID $=1.0500$

$\mathrm{D}=$ DISPLACER DIAMETER $=2.0000$ INCHES

H = IMMERSION DEFTH (FROM EQUATION) =

0.7048 CENTIMETERS

0.2775 INCH
} 


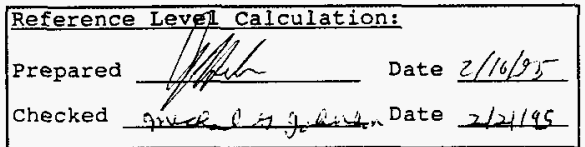

TANK NUMBER

$s-112$

BOTTOM OF TANK TO RISER DIMENSION

DRAWING NUMBER

( $\mathrm{H}-2-37381)$

RISER NUMBER

RISER ELEVATION (Ft.)

664.0200

TANK INSIDE BOTTOM ELEVATION (Ft.) -

618.4300

TANK SIDE-BOTTOM ELEVATION (Ft.) -

N/A

RISER TO TAMK BOTTOM ELEVATTON

(Ft.)

45.5900

547.08

DETERMINING REFERENCE LEVEL:

$1 / 16$ GASKET a 508 COMPRESSION (In,) +

0.0313

(B)

PVC FLANGE (OPTIONAL) (In.) +

1/8 GASKET $50 \%$ COMPRESSION (In.) + BALL VALVE fLANGE to FLANGe (In,) +

BALL INSET DIM (FROM TOP) (In.) -

IMMERSION DEPTH ON SOLIDS (In.) +

REF RRENCE LEVEL (IN.)

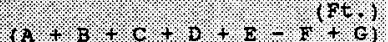

$1.0000 \quad$ (C)

0.0625 (D)

1.4700 (F)

- (G)
9.0000 (E)

\section{PARAMETERS}

$\mathbf{T} \mathbf{T}=580.30$

$\mathrm{UR}=580.30$

$\mathrm{MH}=574.70$

$\mathrm{HH}=567.70$

$\mathrm{HA}=561.70$

$\mathrm{RL}=555.70$

$A N=N / A$

$A M=N / A$

$T I=\ldots S 112$

ML $=1.00$

$\mathrm{LA}=12.00$

$L L=6.00$

$\mathrm{WT}=\mathrm{EDE}$ 


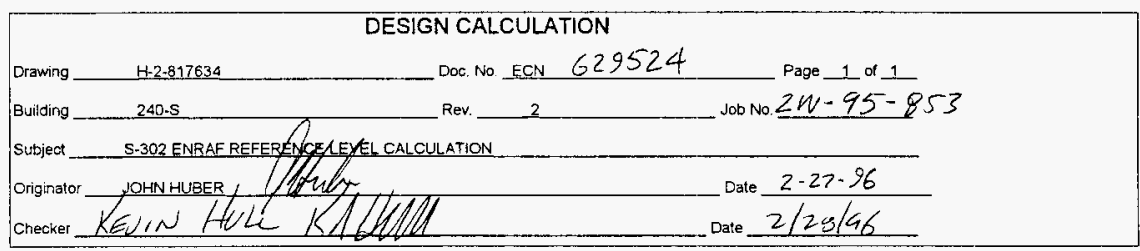

TANK NUMBER $\mathrm{S}-302$

BOTTOM OE TANK TO RISER DIMENSION

DRAWING NUMBER (H-2-5211)

RISER NUMBER (N/A)

RISER ELEVATION (Ft.) 678.7300

TANK INSIDE BOTTOM ELEVATION (Ft ) - 646.5000 RISER TO TANK BOTTOM ELEVATION

(FE) $\quad 32.2300$

(A)

\section{DETERMINING REFERENCE IEVEL:}

$1 / 16$ GASKET @ 50\% COMPRESSION (In.) + 0.0313 (B)

PVC FLANGE (OPTIONAL) (In.) + 0.0000 (C)

$1 / 8$ GASKET \& 50\% COMPRESSION (In.) + 0.0000 (D)

BALL VALVE FLANGE TO FLANGE (In.) + 9.0000 (E)

BALL INSET DIM (EROM TOP) (In.) - 1.4700 (E)

IMMERSION DEPTH IN SOLIDS (In.) + 0 (G)

NEW BALL VALVE, $\mathrm{H}-2$ -

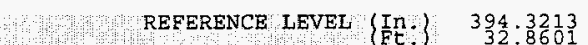

$(\mathrm{A}+\mathrm{B}+\mathrm{C}+\mathrm{D}+\mathrm{E}-\mathrm{F}+\mathrm{Ft})$ 


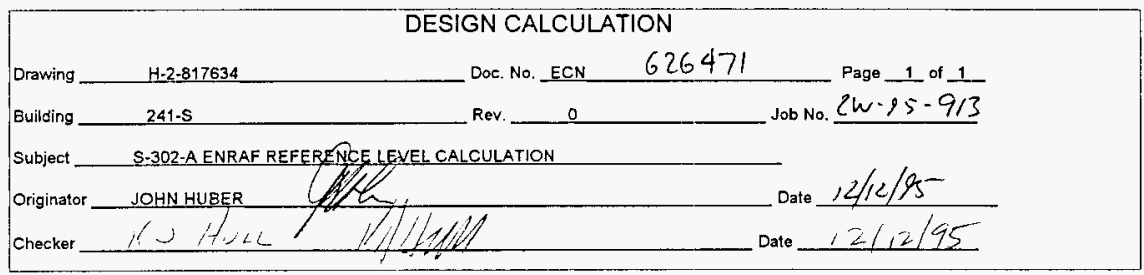

$$
\begin{array}{r}
\text { TANK NUMBER } \\
\text { BOTTOM OF TANK TO RISER }
\end{array}
$$

$$
\text { DRAWING NUMBER ( } \mathrm{H}-2-1795)
$$

RISER NUMBER (N/A)

RISER ELEVATION (Ft.) 662.6400

TANK INSIDE BOTTOM ELEVATION -630.5000

RISER TO TANK BOTTOM ELEVATION $\begin{array}{r}32.1400 \\ 385.68\end{array}$

DETERMINING REFERENCE LEVEL:

1/16 GASKET @ 50\% COMPRESSSTON

PVC FLANGE (OPTIONAL) (In.) + $1 / 8$ GASKET @ $50 \%$ COMPRESSION

BALL VALVE FLANGE TO FIANGE

$(\mathrm{In})+$,9.0000 (E)

BALI INSET DIM (FROM TOP) (In.) -

IMMERSION DEPTH IN SOLIDS (In.) +

REEERENCE LEVEL ( In. $) \quad 393.2413$
(A)

$$
0.0313 \text { (B) }
$$

0.0000 (C)

$0.0000 \quad$ (D)
$(\mathrm{A}+\mathrm{B}+\mathrm{C}+\mathrm{D}+\mathrm{E}-\mathrm{F}+\mathrm{G})$ 


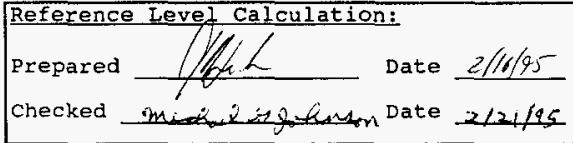

TANK NUMBER

$5 x-101$

BOTTOM OF TANK TO RISER DIMENSION

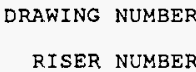

$(\mathrm{H}-2-37855)$

(4)

RISER ELEVATION (Ft.)

663.5100

TANK INSIDE BOTTOM ELEVATION (Ft.) - 611.1100

TANK SIDE-BOTTOM ELEVATION (Ft.) -

$\mathrm{N} / \mathrm{A}$

AIS BR TO TANK BOT TOM ELQWATION IPt.

$(1+1)$

52.4000

628.8

(A)

DETERMINING REFERENCE LEVEL:

$1 / 16$ GASKET @ 508 COMPRESSION (In.) + 0.0313

PVC FLANGE (OPTIONAL) (In.) + 1.0000 (C)

$1 / 8$ GASKET a 508 COMPRESSION (In.) + 0.0625 (D)

BALI VALVE FLANGE TO FLANGE (In.) + 9.0000 (E)

BALL INSET DIM (FROM TOP) (In.) - 1.4700 (F)

IMMERSION DEPTH ON SOLIDS (In.) +

RERERENCE $\mathrm{HEVET} / \mathrm{H} / \mathrm{l}$

$(\mathrm{A}+\mathrm{B}+\mathrm{C}+\mathrm{D}+\mathrm{B}+\mathrm{B}+\mathrm{Pt})$
637.4238

53.1186
PARAMETERS

$\mathrm{TT}=662.02$

$\mathrm{UR}=662.02$

$M H=656.42$

$\mathrm{HH}=649.42$

$\mathrm{HA}=643.42$

$\mathrm{RL}=637.42$

$A N=N / A$

$A M=N / A$

$\mathrm{TI}=. \mathrm{SX} 101$

$M L=1.00$

$I A=12.00$

$L L=6.00$

$W T=E D E$ 


\begin{tabular}{|c|c|c|}
\hline \multicolumn{3}{|c|}{ Reference Level Calculation: } \\
\hline Prepared & Sthe Date & $21 / 1 / 95$ \\
\hline Checked & minex 6 if $j$ Lenden Date & $3 / 24 / 95$ \\
\hline
\end{tabular}

TANK NUMBER

BOTTOM OF TANK TO RISER DIMENSION

DRAWING NUMBER

RISER NUMBER

$(H-2-37855)$

(4)

RISER ELEVATION (Ft.) 662.4200

TANK INSIDE BOTTOM ELEVATION (Ft.) - 610.1100

TANK SIDE-BOTTOM ELEVATION (Ft.) -

$\mathrm{N} / \mathrm{A}$

\section{RISBR TO HANK BOT TON GLEVATION, (Ft.)}

52.31 .00

627.72

\section{DETERMINING REFERENCE LEVEL:}

$1 / 16$ GASKET @ $50 \%$ COMPRESSION (In.) +

0.0313

PVC FLANGE (OPTIONAL) (In.) +

1.0000

$1 / 8$ GASKET a 508 COMPRESSION (In.) +

0.0625

(D)

BALl VALVE FLANGe to FLANGE (In.) +

9.0000

BALL INSET DIM (FROM TOP) (In.) -

IMMERSION DEPTH ON SOLIDS (In.) +

1.4700

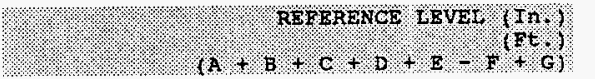

636.3437

53.0286 


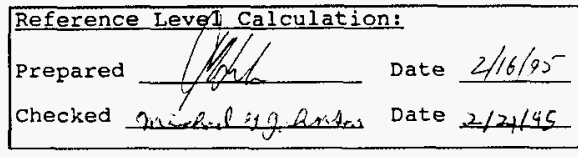

TANK NUMBER

BOTTOM OF TANK TO RISER DIMENSION

$$
\begin{array}{r}
\text { DRAWING NUMBER } \\
\text { RISER NUMBER }
\end{array}
$$

$(\mathrm{H}-2-37855)$

RISER ELEVATION (Ft.)

TANK INSIDE BOTTOM ELEVATION (Ft.) - 609.1100

TANK SIDE-BOTTOM ELEVATION (Ft.) -

RISER TO TANK BOTTOM ELEVATION.

$(P t)$

(In.) $s x-103$

661.4400

$\mathrm{N} / \mathrm{A}$

52.3300

627.96

\section{PARAMETERS}

$$
T T=661.18
$$

$\mathrm{UR}=661.18$

$\mathrm{MH}=655.58$

$\mathrm{HH}=648.58$

$\mathrm{HA}=642.58$

$\mathrm{RL}=636.58$

$\mathrm{AN}=\mathrm{N} / \mathrm{A}$

$A M=N / A$

$\mathrm{TI}=. \mathrm{S} \times 103$

$M L=1.00$

$\mathrm{LA}=12.00$

$\mathrm{LL}=6.00$

(A)

\section{DETERMINING REFERENCE LEVEL:}

$1 / 16$ GASKET @ 508 COMPRESSION (In.) +0.0313 (B)

PVC FLANGE (OPTIONAL) (In.) + 1.0000 (C)

$1 / 8$ GASKET @ 508 COMPRESSION (In.) +0.0625 (D)

BaLl VALVE FLANGe to FLANGE (In.) + 9.0000 (E)

BALL INSET DIM (FROM TOP) (In.) - 1.4700 (F)

IMMERSION DEPTH ON SOLIDS (In.) $+\quad 0$ (G)

636.5838

53.0486 


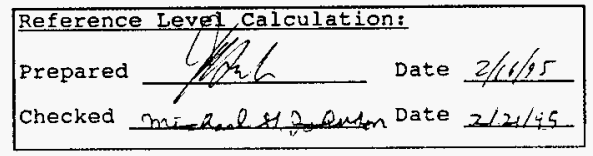

TANK NUMBER

BOTTOM OF TANK TO RISER DIMENSION

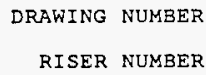

$(\mathrm{H}-2-37855)$

(4)

RISER ELEVATION (Ft.) 663.4500

TANK INSIDE BOTTOM ELEVATION (Ft.) - 611.1100

TANK SIDE-BOTTOM ELEVATION (Ft.) -

$\mathrm{N} / \mathrm{A}$

\section{RTSER TO TANX BOTTOH ELEVATTON (Ft.)}

(In.)

52.3400

628.08

(A)

DETERMINING REFERENCE LEVEL:

$1 / 16$ GASKET \& $50 \%$ COMPRESSION (In.) +0.0313

PVC FLANGE (OPTIONAL) (In.) +

1.0000

(C)

$1 / 8$ GASKET a 508 COMPRESSION (In.) +

0.0625

(D)

BALI VALVE FLANGE to Flange (In.) +

BALL INSET DIM (FROM TOP) (In.) -

IMMERSTON DEPTH ON SOLIDS (In.) +

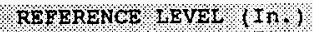

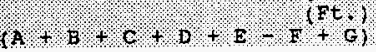

$9.0000 \quad(\mathrm{E})$

1.4700 (F)

o (G)

\section{PARAMETERS}

$\mathrm{TT}=661.30$

$\mathrm{UR}=661.30$

$\mathrm{MH}=655.70$

$\mathrm{HH}=648.70$

$\mathrm{HA}=642.70$

$R L=636.70$

$A N=N / A$

$A M=N / A$

$\mathrm{TI}=. \mathrm{S} \times 104$

$M I=1.00$

$L A=12.00$

$L L=6.00$

$\mathrm{WT}=\mathrm{EDE}$ 


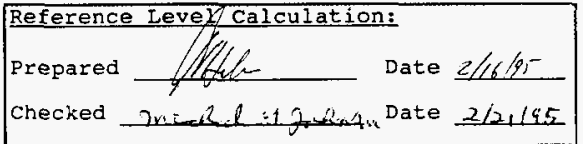

TANK NUMBER

BOTTOM OF TANK TO RISER DIMENSION

DRAWING NUMBER

RISER NUMBER

RISER ELEVATION (Ft.) 662.5000

TANK INSIDE BOTTOM ELEVATION (Ft.) - 610.1100

TANK SIDE-BOTTOM ELEVATION (Ft.) -

$\mathrm{N} / \mathrm{A}$

\begin{abstract}
RISER TO TANK BOTTOM EIEVATION (Et.)
(In.)
\end{abstract}

52.3900

628.68

DETERMINING REFERENCE LEVEL:

$1 / 16$ GASKET C 508 COMPRESSION (In.) +

0.0313

(B)

PVC FLANGE (OPTIONAL) (In.) +

$1 / 8$ GASKET 508 COMPRESSION (In.) +

BALl VALVE FLANGE TO FLANGE (In.) +

BALL INSET DIM (FROM TOP) (In.) -

IMMERSION DEPTH ON SOLIDS (In.) +

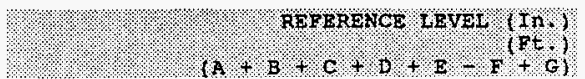

1.0000 (C)

$0.0625 \quad$ (D)

9.0000

1.4700

0

\section{PARAMETERS}

$\mathrm{TT}=661.90$

$\mathrm{UR}=661.90$

$\mathrm{MH}=656.30$

$\mathrm{HH}=649.30$

$\mathrm{HA}=643.30$

$R I=637.30$

$A N=N / A$

$A M=N / A$

$\mathrm{TI}=. \mathrm{SX} 105$

$M I=1.00$

$\mathrm{LA}=12.00$

$L I=6.00$

$\mathrm{WT}=\mathrm{EDE}$ 
TANK NUMBER SX-106

BOTTOM OF TANK TO RISER DIMENSION

$$
\text { DRAWING NUMBER ( } \mathrm{H}-2-37855)
$$

RISER NUMBER

RISER ELEVATION (Ft.)

661.4700

TANK INSIDE BOTTOM ELEVATION (Ft.) - 609.1100

TANK SIDE-BOTTOM ELEVATION (Ft.) $N / A$

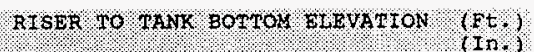

DETERMINING REFERENCE LEVEL:

1/16 GASKET \& $50 \%$ COMPRESSION (In.) + PVC FLANGE (OPTIONAL) (In.) +

$1 / 8$ GASKET a $50 \%$ COMPRESSION ( $\mathrm{In}$.) + BALL VALVE FLANGE TO FLANGE (In.) + BALI INSET DIM (EROM TOP) (In.) IMMERSION DEPTH IN SOLIDS (In.) +

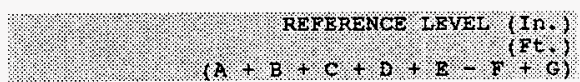

$$
0.0313
$$

1.0000

(C)

0.0625

(D)

9.0000

1. 2100

0

(G)

\section{PARAMETERS}

$\mathrm{TT}=662.13$

$\mathrm{UR}=662.13$

$\mathrm{MH}=656.53$

$\mathrm{HH}=649.53$

$\mathrm{HA}=643.53$

$R I=637.20$

$A N=226.60$

$\mathrm{AM}=176.60$

$\mathrm{TI}=. \mathrm{S} \times 106$

$\mathrm{MI}=1.00$

$L A=12.00$

$\mathrm{LI}=6.00$

$W T=E D E$ 
THIS PAGE RESERVED FOR SX-107 
THIS PAGE RESERVED FOR SX-108 


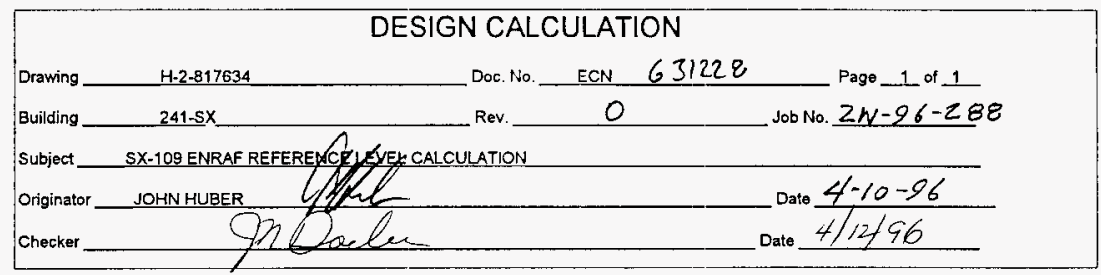

TANK NUMBER SX-109

BOTTOM OF TANK TO RISER DIMENSION

DRAWING NUMBER (H-2-37855)

RISER NUMBER

(2)

RISER ELEVATION (FE.) 561.4200

TANK CL BOTTOM ELEVATION (Ft.) - 609.1100

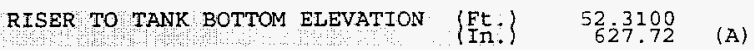

DETERMINING REFERENCE LEVEL:

1/16 GASKET \& 50\% COMPRESSION (In.) +

$0.0000 \quad$ (B)

PVC FLANGE (OPTIONAI) (In.) +

0.0000 (C)

$1 / 8$ GASKET @ 50\% COMPRESSION (In.) + 0.0625 (D)

BALL VALVE ELANGE TO FLANGE (In.) + 9.0000 (E)

BALL INSET DIM (FROM TOP) (In.) - 1.4700 (F)

IMMERSION DEPTH IN SOLIDS (In.) + 0 (G)

REFERENCE LEVEL ( $\left.\frac{T n}{F E}\right) \quad 635.3125$

$(A+B+C+D+E-F+G$ 
THIS PAGE RESERVED FOR SX-110 
THIS PAGE RESERVED FOR SX-111 
THIS PAGE RESERVED FOR SX-112 
THIS PAGE RESERVED FOR SX-113 
THIS PAGE RESERVED FOR SX-114 
THIS PAGE RESERVED FOR SX-115 


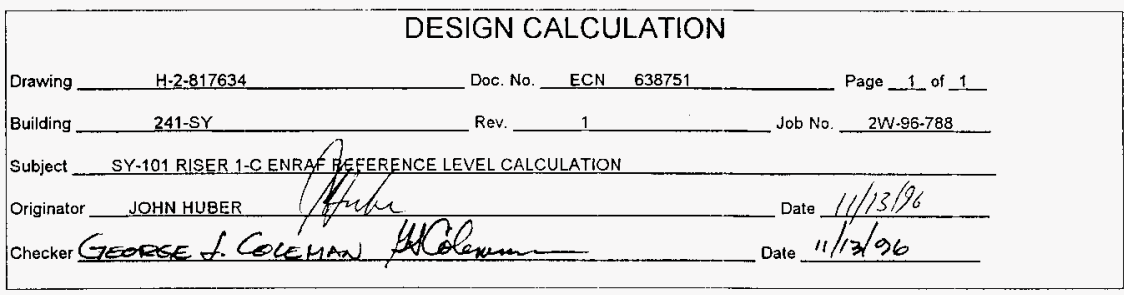

TANK NUMBER SY-101

\section{BOTTOM OF TANK TO RISER DIMENSION}

\begin{tabular}{|c|c|c|c|}
\hline DRAWING NUMBER & & $-2-79556)$ & \\
\hline RISER NUMBER & & (1C) & \\
\hline RISER ELEVATION (Ft.) & & 672.4100 & \\
\hline TOP OF CONC. FOUNDATION (Ft.) & - & 616.5000 & \\
\hline ANN. BOTTOM PL. THHCKNESS (Ft.) & - & 0.0313 & \\
\hline INSUL. CONC. THICKNESS (Ft.) & - & 0.6667 & \\
\hline PRI. BOTTOM PL. THICKNESS (Ft.) & - & 0.0417 & \\
\hline $\begin{array}{l}\text { RISER TO TANK BOTTOM ELEVATION (Ft.) } \\
\text { (in.) }\end{array}$ & & $\begin{array}{r}55.1703 \\
662.0436\end{array}$ & (A) \\
\hline \multicolumn{4}{|l|}{ DETERMINING REFERENCE LEVEL: } \\
\hline 1/16 GASKET @ 50\% COMPRESSION (In.) & + & 0.0313 & (B) \\
\hline PVC FLANGE (OPTIONAL) (In.) & + & 1.0000 & (C) \\
\hline 1/8 GASKET @ 50\% COMPRESSION (in.) & + & 0.0625 & (D) \\
\hline BALL VALVE FLANGE TO FLANGE (In.) & + & 9.0000 & (E) \\
\hline BALL INSET DIM (FROM TOP) (In.) & - & 1.4700 & $(F)$ \\
\hline IMMERSION DEPTH IN SOLIDS (In.) & + & 0.0000 & (G) \\
\hline $\begin{array}{r}\text { REFERENCE LEVEL (In.) } \\
(\mathrm{At}+\mathrm{B}+\mathrm{C}+\mathrm{D}+\mathrm{E}-\mathrm{F}+\mathrm{G})\end{array}$ & & $\begin{array}{r}670.6674 \\
55.8889\end{array}$ & \\
\hline
\end{tabular}




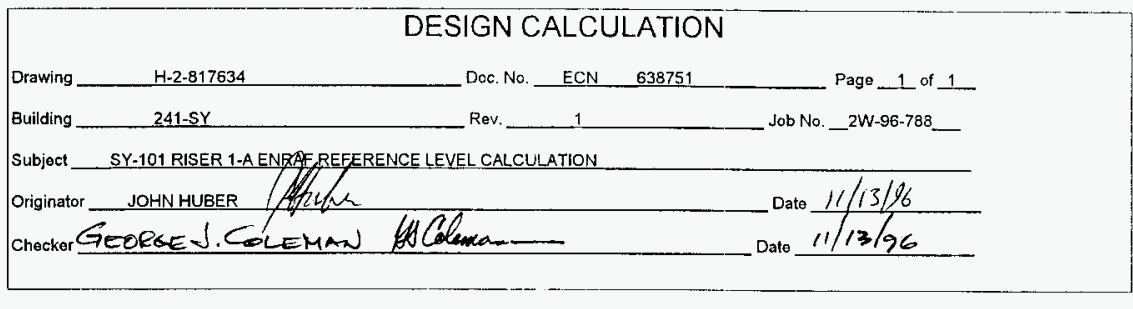

TANK NUMBER

SY-101

BOTTOM OF TANK TO RISER DIMENSION

DRAWING NUMBER $\quad(\mathrm{H}-2-79556)$

RISER NUMBER (1A)

RISER ELEVATION (Ft.) $\quad 672.6500$

TOP OF CONC. FOUNDATION (Ft.) - $\quad 616.5000$

ANN. BOTTOM PL. THICKNESS (Ft.) - 0.0313

INSUL. CONC. THICKNESS (Ft.) - $\quad 0.6667$

PRI. BOTTOM PL. THICKNESS (Ft.) - 0.0417

FOR TANK BOTTOM DIMENSIONS,

REFER TO H-2-37772

RISER TO TANK BOTTOM ELEVATION (Ft.)

(in.)

55.4103

664.9236

(A)

\section{DETERMINING REFERENCE LEVEL:}

1/16 GASKET@50\% COMPRESSION (In.) +

$0.0313 \quad(B)$

PVC FLANGE (OPTIONAL) (ln.) + N/A (C)

1/8 GASKET@50\% COMPRESSION (In.) +

N/A (D)

BALL VALVE FLANGE TO FLANGE $(\ln )+$

$9.0000 \quad(E)$

BALL INSET DIM (FROM TOP) (In.) -

$1.2100 \quad(F)$

IMMERSION DEPTH IN SOLIDS (In.) +

$0.0000 \quad(G)$

REFERENCE LEVEL (ln.)

(Ft.)

672.7449

56.0621

IMMERSION DEPTH CHANGED

TO ZERO SINCE DISPLACER

SITS ON SOLIDS

$(A+B+C+D+E-F+G)$ 
TANK NUMBER

BOPYOM OF TANK TO RISER DIMENSION

\section{DRAWING NUMBER}

RISER NUMBER

RISER ELEVATION (Ft.)

672.5100

TANK INSIDE BOTTOM ELEVATION (Ft.) -

TANK SIDE-BOTTOM ELEVATION (Ft.) -

\section{RISER TO TANK BOT TOM ELZVATION}

$\mathrm{Ft}$

(In)

$S Y-102$

617.2396

\section{DETERMINING REFERENCE LEVEL:}

$1 / 16$ GASKET @ $50 \%$ COMPRESSION (In.) + PVC FLANGE (OPTIONAL) (In.) +

$1 / 8$ GASKET a $50 \%$ COMPRESSION (In.) + BALL VALVE FLANGE TO FLANGE (In.) + BALL INSET DIM (FROM TOP) (In.) IMMERSION DEPTH AT $1.05 \mathrm{sp.} \mathrm{G.} \mathrm{(In.)} \mathrm{+}$

$$
\begin{aligned}
& \text { REREREICE LEVEI (IO) }
\end{aligned}
$$

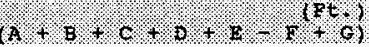

\section{* IMMERS ION DEPTH CALCULATION}

$$
\begin{aligned}
& \text { GOVERNING EQUATION } \\
& \mathrm{H}=(4 * \mathrm{Fb}) /(\mathrm{Sg} * \mathrm{Pi} * \mathrm{D} \star 2) \\
& \mathrm{Fb}=\text { BOUYANT FORCE }=\text { SET POINT = } \\
& \mathrm{Sg}=\text { SPECIFIC GRAVITY OE LIQUID }= \\
& \mathrm{D}=\text { DISPLACER DIAMETER }= \\
& \mathrm{H}=\text { IMMERSION DEPTH (FROM EQUATION) }=
\end{aligned}
$$

0.0313

1.0000

0.0625

9.0000

1.2100

0.2774923

672.4060 56.0338

\section{PARAMETERS}

$$
\begin{aligned}
& \mathrm{TT}=697.06 \\
& \mathrm{UR}=697.06 \\
& \mathrm{MH}=691.46 \\
& \mathrm{HH}=684.46 \\
& \mathrm{HA}=678.46 \\
& \mathrm{RL}=672.41 \\
& \mathrm{AN}=301.00 \\
& \mathrm{AM}=251.00 \\
& \mathrm{TI}=.5 Y 102 \\
& \mathrm{ML}=1.00 \\
& \mathrm{LA}=12.00 \\
& \mathrm{LL}=6.00 \\
& \mathrm{WT}=\mathrm{EDE}
\end{aligned}
$$


TANK NUMBER SY-103

BOTTOM OF TANK TO RISER DIMENSION

$$
\begin{array}{r}
\text { DRAWING NUMBER } \\
\text { RISER NUMBER }
\end{array}
$$

(H-2-85104)

RISER ELEVATION (Ft.)

672.5300

TANK INSIDE BOTTOM ELEVATION (Ft.) -

TANK SIDE-BOTTOM ELEVATION (Ft.) -

NISER 10 MAK BOT TOM ETAVATION (rt,

tnol
617.2396

$\mathrm{N} / \mathrm{A}$

55.2904

663.4848
PARAMETERS

$\mathrm{TT}=697.30$

$\mathrm{UR}=697.30$

$\mathrm{MH}=691.70$

$\mathrm{HH}=684.70$

$\mathrm{HA}=678.70$

$\mathrm{RL}=672.65$

$A N=298.90$

$A M=248.90$

$\mathrm{TI}=$

$M L=$

$I A=$

II $=$

(A)

DETERMINING REFERENCE LEVEL:

$1 / 16$ GASKET @ 508 COMPRESSION (In.) + 0.0313 (B)

PVC FLANGE (OPTIONAL) (In.) + 1.0000 (C)

$1 / 8$ GASKET a 508 COMPRESSION (In.) + 0.0625 (D)

BALL VALVE FLANGE TO FLANGE (In.) + 9.0000 (E)

BALL INSET DIM (FROM TOP) (In.) - 1.2100 (F)

IMMERSION DEPTH AT $1.05 \mathrm{sp} . \mathrm{G} .(\mathrm{In})+$.0.2774923 (G)

RQRERENOD LEVED In.) 672.6460

56.0538

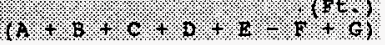

* IMMERSION DEPTE CALCULATION

\footnotetext{
GOVERNING EQUATION

$\mathrm{H}=(4 * \mathrm{Fb}) /(\mathrm{Sg} * \mathrm{P} i * \mathrm{D} * 2)$

$\mathrm{Fb}=$ BOUYANT FORCE $=$ SET POINT $=15.0000$ GRAMS

$S g=$ SPECIFIC GRAVITY OF LIQUID = 1.0500

$D=$ DISPLACER DIAMETER $=2.0000$ INCHES

$\begin{array}{lll}H=\text { IMMERSION DEPTH (FROM EQUATION) }= & 0.7048 \text { CENTIMETERS } \\ 0.2775 \text { INCH }\end{array}$
} 


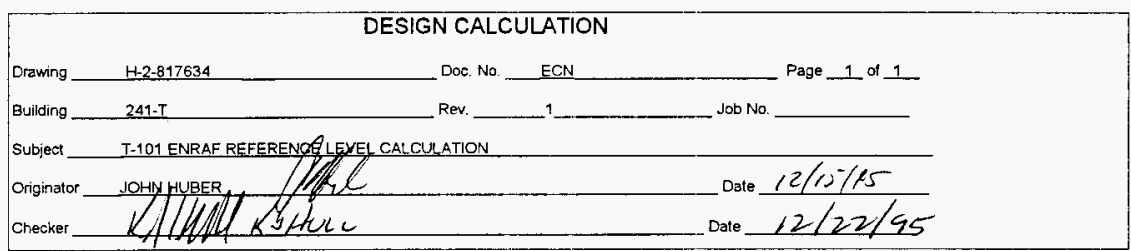

)

TANK NUMBER

$\mathrm{T}-101$

BOTTOM OF TANK TO RISER DIMENSION

DRAWING NUMBER (H-2-37909)

RISER NUMBER (1)

RISER ELEVATION (Ft.) 673.6200

TANK CL BOTTOM ELEVATION (Ft.) - 635.0000

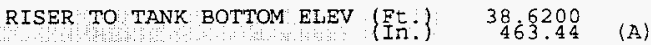

DETERMINING REFERENCE LEVEL:

$1 / 16$ GSKT 50\% COMPRESSION (In.) + 0.0313 (B)

FVC FLANGE (OPTIONAL) (In.) +1.0000 (C)

$1 / 8$ GSKT @ 50\% COMPRESSION (In.) + 0.0625 (D)

BALL VALVE FLANGE TO FLANGE (In.) + 9.0000 (E)

BALI INSET DIM (FROM TOP) (In,) - 1.2100 (F)

IMMERSION DEPTH ON SOLIDS (In.) + 0 (G)

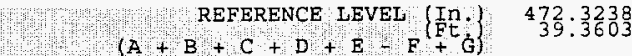




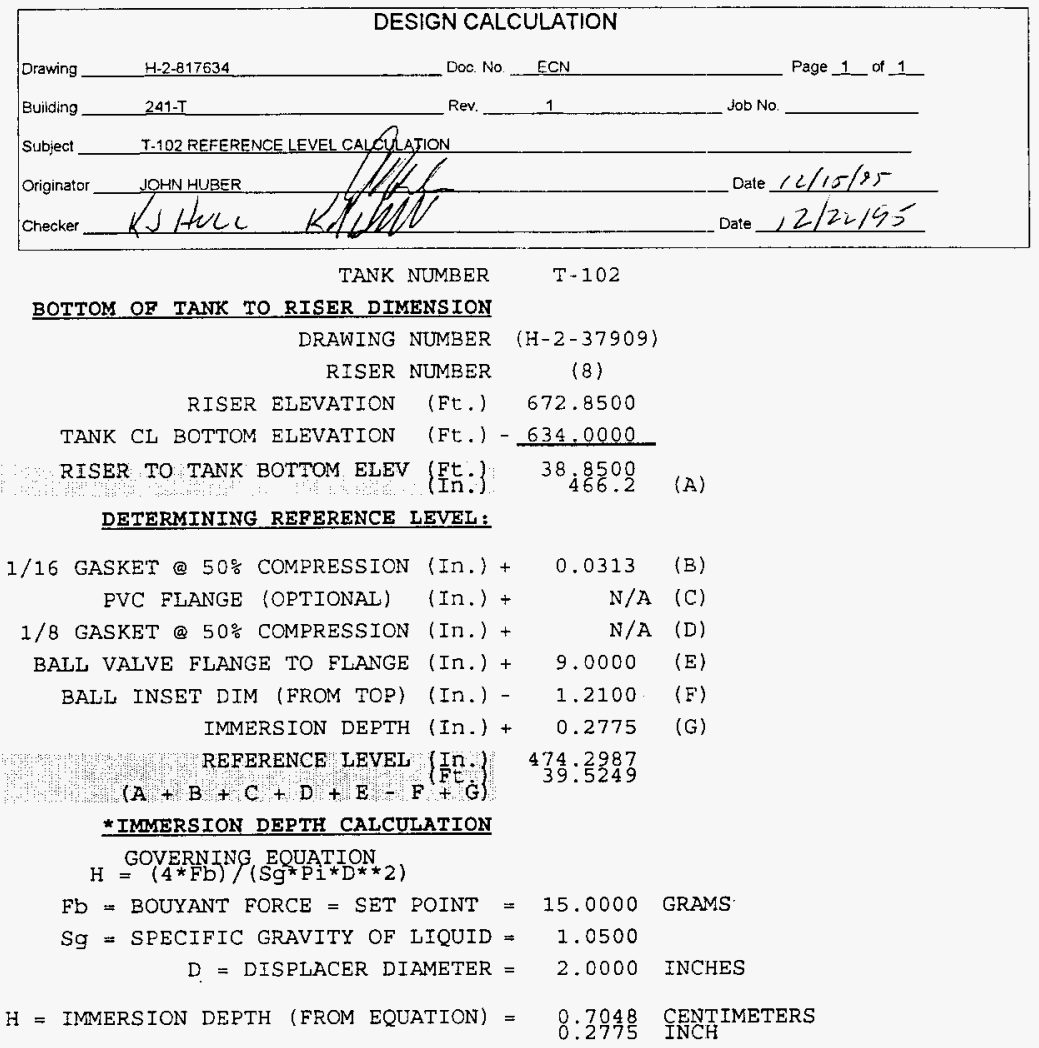




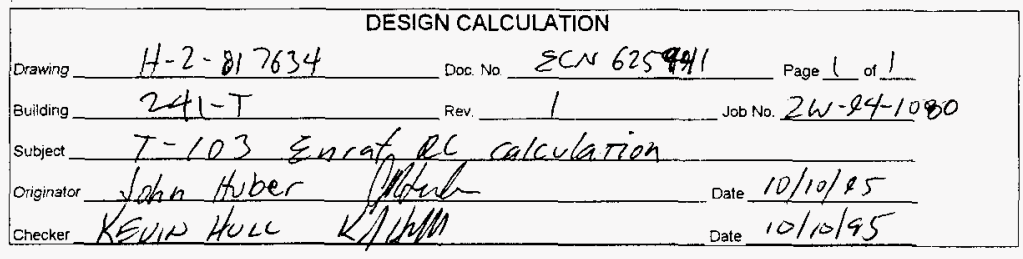

$$
\text { TANK NUMBER }
$$

$T-103$

BOTTOM OF TANK TO RISER DIMENSION

DRAWING NUMBER (H-2-37909)

RISER NUMBER

(1)

$$
\text { RISER ELEVATION (FE.) } 671.8300
$$

TANK CL BOTTOM ELEVATION (Ft.) -633.0000

RISER TO TANK BOTTOM ELEV (FE.) 38.8300 (A)

DETERMINING REFERENCE LEVEL:

1/16 GASKET @ 50\% COMPRESSION (In.) + 0.0313 (B)

PVC FLANGE (OPTIONAL) (In.) + 1.0000 (C)

$1 / 8$ GASKET @ 50\% COMPRESSION (In.) + 0.0625 (D)

BALL VALVE FLANGE TO FLANGE (In.) + 9.0000 (E)

BALI INSET DIM (FROM TOP) (In.) - 1.4700 (E)

IMMERSION DEPTH (In.) + 0.2775 (G)

$\left(\mathrm{A}+\mathrm{B}+\mathrm{C}+\mathrm{D}+\mathrm{E}-\mathrm{F}(\mathrm{F}+\mathrm{G}) \quad \begin{array}{l}\text { REFERENCE LEVEL } \\ 39.5718\end{array}\right.$

* IMMERSION DEPTH CALCULATION

$\mathrm{H}=\left(4^{\star} \mathrm{Fb}\right) /\left(\mathrm{Sg}^{\star} \mathrm{P} i \mathrm{P}^{\star} \mathrm{D}^{\star} 2\right)$

$\mathrm{Fb}=$ BOUYANT FORCE $=$ SET POINI $=15.0000$ GRAMS

$\mathrm{Sg}=$ SPECIFIC GRAVITY OF LIQUID $=1.0500$

$\mathrm{D}=$ DISPLACER DIAMETER $=2.0000$ INCHES

$\mathrm{H}=$ IMMERSION DEPTH (FROM EQUATION) $=0.7048$ CENTTMETERS 


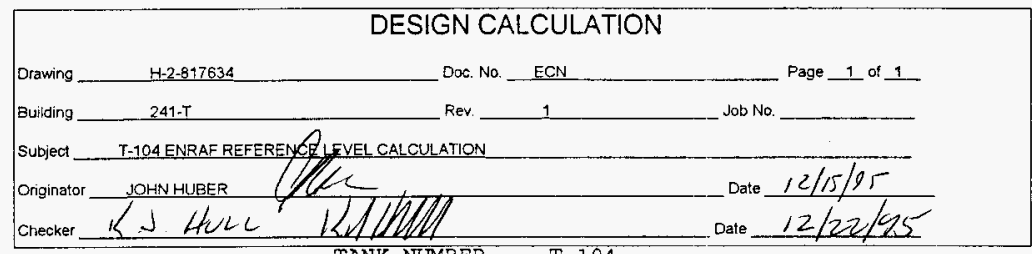

TANK NUMBER $\mathrm{T}-104$

BOTTOM OF TANK TO RISER DIMENS ION

DRAWING NUMBER (H-2-37909)

RISER NUMBER

(5)

RISER ELEVATION (Ft.) 673.8100

TANK CL BOTTOM ELEV. (FE.) - 635.0000

RISER TO TANK BOTTOM ELEV (Ft:) $\begin{array}{rlll}38.8100 & \\ 465.72 & \text { (A) }\end{array}$

DETERMINING RERERENCE LEVEL:

1/16 GASKET @ 50\% COMPRESSION (In.) +

0.0313 (B) 0

PVC FLANGE (OPTIONAL) (In.) +

1/8 GASKET @ 50\% COMPRESSION (In.) +
BALL VALVE FLANGE TO FLANGE (In.) +

0.0000

(C)

0.0000

(D) REPLACING MANUAL TAFE, NO PVC LINER

BALI INSET DIM (FROM TOP) (In.) -

9.0000

(E)

IMMERSION DEPTH IN SOLIDS (In.) +

1.2100

(F) USING OLD BALL VALVE, H-2-817634 F/N 20

REFERENCE LEVEL ( In.)

$(A+B+C+D+B-F+(F)$

473.5412
39.4618

(G) REVIEW OF MOST RECENT IN.TANK PHHOTOS

INDICATES PLUMMET IS LIKELY OVER

SLUDGEISOLIDS - NO IMMERSION DEPTH 


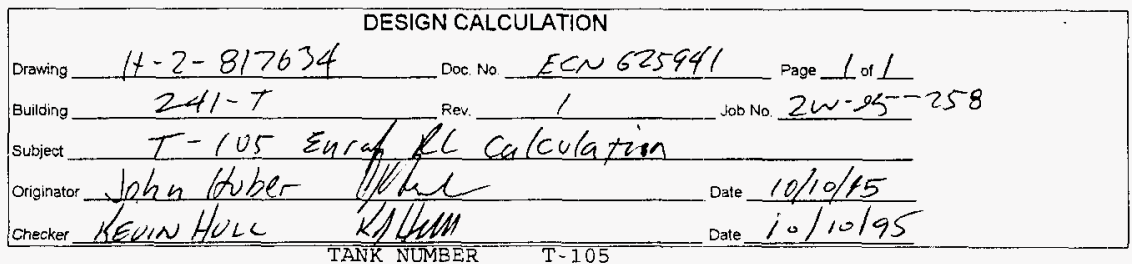

BOTTOM OF TANK TO RISER DIMENSION

DRAWING NUMBER (H-2-37909)

RISER NUMBER

RISER ELEVATION (Ft.) 672.8100

TANK INSIDE BOTTOM ELEVATION (Ft, ) - 634.0000

RISER TO TANK BOTTOM ELEVATION $\begin{array}{r}38.8100 \\ 465.72\end{array}$

(A)

DETERMINING REFERENCE LEVED:

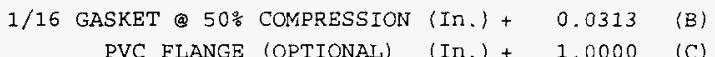

$1 / 8$ GASKET @ 50\% COMPRESSION (In.) + 0.0625 (D)

BALL VALVE FIANGE TO FLANGE (In.) + 9.0000 (E)

BALL INSET DIM (FROM TOP) (In.) - 1.4700 (F)

IMMERSION DEFTH IN SOLIDS (In.) + 0 (G)

REFERENCE LEVEL (In. $\} \begin{array}{r}474.3437 \\ 39.5286\end{array}$

$(\mathrm{A}+\mathrm{B}+\mathrm{C}+\mathrm{D}+\mathrm{E}-\mathrm{E}+\mathrm{Gt}\}$ 


$$
\begin{array}{r}
\text { WHC-SD-WM-CN-078 } \\
\text { REVISION } 0
\end{array}
$$

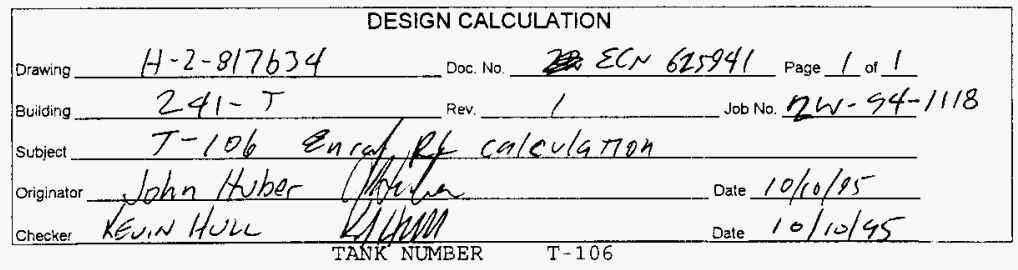

BOTTOM OF TANK TO RISER DIMENSION

$$
\begin{array}{rrr} 
& \text { DRAWING NUMBER } & \text { (H-2-37909) } \\
\text { RISER NUMBER } & (1) \\
\text { RISER ELEVATION } & \text { (Ft.) } & 671.8000 \\
\text { TANK INSIDE BOTTOM ELEVATION } & \text { (Ft.) } & -633.0000 \\
\hline \text { RISER TO TANK BOTTOM ELEV } & \text { (Ft.) } & 38.0000 \\
\text { (In.) } &
\end{array}
$$

(A)

DETERMINING REFERENCE LEVEL:

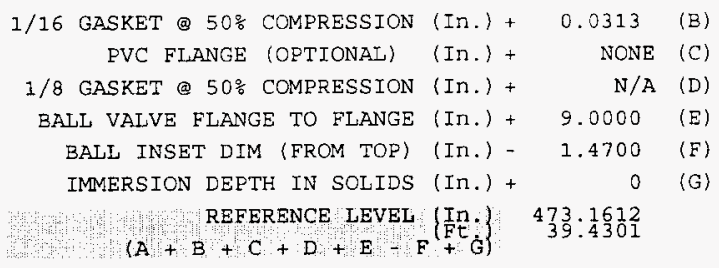

A- 134 


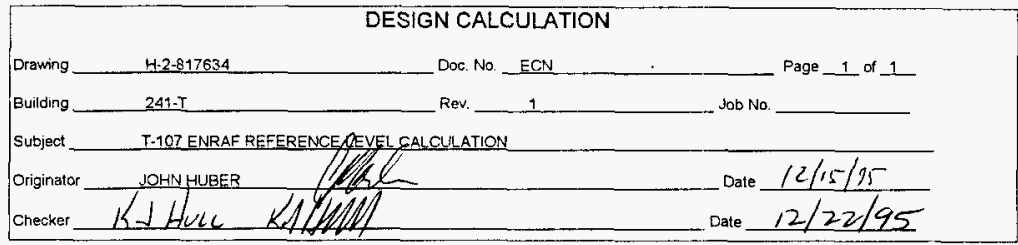

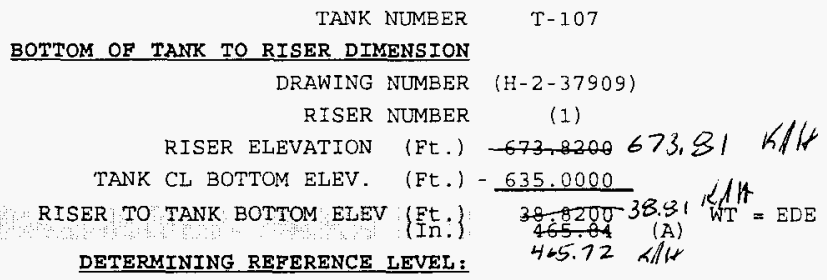

\section{DETERMINING REEERENCE LEVEL: $465.72 \mathrm{a} / \mathrm{K}$}

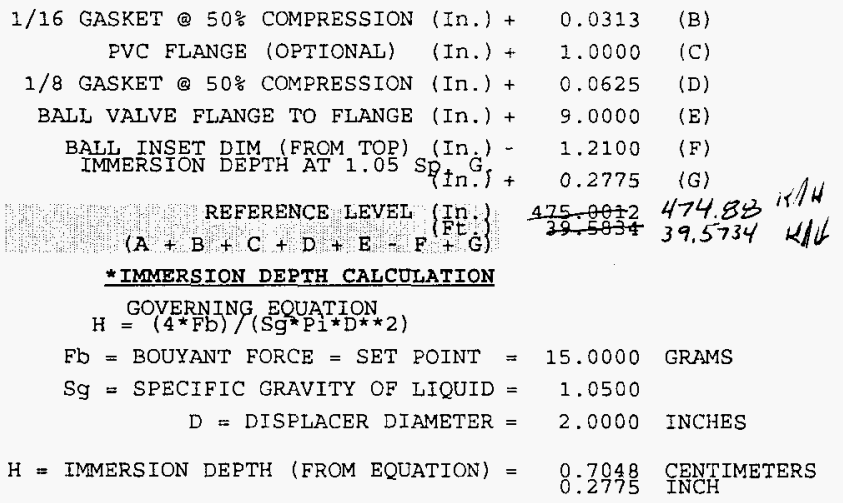




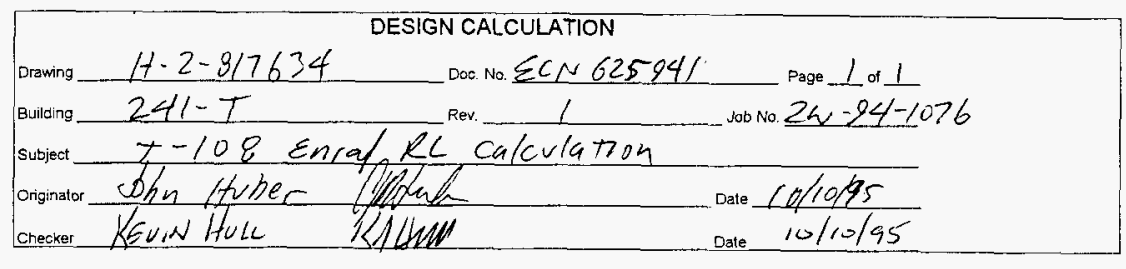

TANK NUMBER T 208

BOT'TOM OF TANK TO RISER DIMENSION

DRAWING NUMBER (H-2-37909)

RISER NUMBER (13)

RISER ELEVATION (Ft.) 674.4600

TANK CL BOT'TOM ELEVATION (Ft.) - 634.0000

RISER TO TANK BOTTOM EEEV \{Et.\} 4044600 (A)

\section{DETERMINING REEERENCE IEVEL:}

1/16 GSKT @ 50\% COMPRESSION (In.) +

PVC FLANGE (OPTIONAL) (In.) +

1/8 GSKT @50\% COMPRESSION (In.) +

0.0313 (B)

BAZL VALVE FLANGE TO FLANGE (In.) +

1.00000

$0.06250 \mathrm{~K}(\mathrm{D})$

BALL INSET DIM (FROM TOP) (In.) -

9.0000 (E)

1.4700 (F)

IMMERSION DEPTH (In.) +

0.2775

1/16 GSKT @ 50\% COMPRESSION (In.) + MULTIPORT FLG (In.) + REFERENCE LEVEL (IN $\}$

$(\mathrm{A}+\mathrm{B}+\mathrm{C}+\mathrm{D}+\mathrm{E}-\mathrm{F}+\mathrm{G}+\mathrm{H}+\mathrm{Ft})$

0.0313

1. 2500

(I) $\mathrm{H}-2-817634$ ASSY 50

$4 \frac{95.7025}{42.394 .6401 \quad k / 1 / 10 / 45}$ 41.22

¿IMMERSION DEPTH CALCULATION

$=(4 * \mathrm{Fb}) /\left(\mathrm{Sg}^{*} \mathrm{PI} \mathrm{I}^{\star} \mathrm{D}^{\star *} 2\right)$

$\mathrm{Fb}=$ BOUYANT FORCE $=$ SET POINT =

15.0000 GRAMS

$S g=$ SPECIFIC GRAVITY OF LIQUID =

1.0500

$\mathrm{D}=$ DISPLACER DIAMETER =

2.0000 INCHES

$H=$ IMMERSION DEFTH (FROM EQN)

$=\quad 0.7048$ CENTIMETERS 


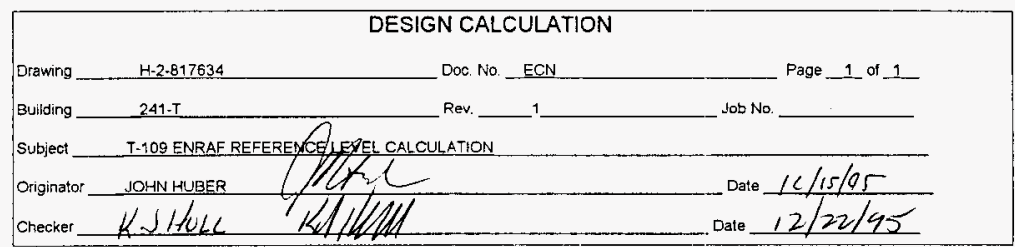

TANK NUMBER T.109

BOTTOM OF TANK TO RISER DIMENSION

DRAWING NUMBER (H-2-37909)

RISER NUMBER (1)

RISER ELEVATION (Ft.) 671.8000

TANK CL BOTTOM ELEVATION (Et.) - 633.0000

RISER TO TANK BOTTOM ELEVATION 38.8000

DETERMINING REFERENCE IEVEL:

1/16 GASKET @50\% COMPRESSION (In.) + 0.0313

PVC FLANGE (OPTIONAL) (In.) + 1.0000 (C)

1/8 GASKET @ 50\% COMPRESSION (In.) + 0.0625 (D)

BALL VALVE FLANGE TO FLANGE (In.) + 9.0000 (E)

BALL INSET DIM (FROM TOP) (In.) - 1.2100 (F)

IMMERSION DEPTH IN SOLIDS (In.) + 0.0000 (G)

$\left.(\mathrm{A}+\mathrm{B}+\mathrm{C}+\mathrm{D}+\mathrm{E}-\mathrm{F}+\mathrm{F}) \quad \begin{array}{l}\text { In } \\ \mathrm{F}\end{array}\right) \quad \begin{array}{r}474.4837 \\ 39.5403\end{array}$ 


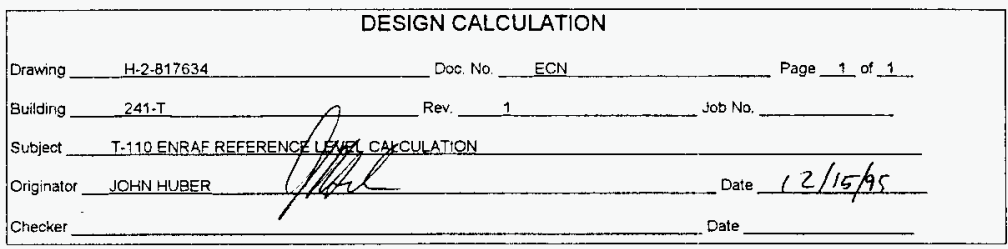

TANK NUMBER T-110

BOTTOM OF TANK TO RISER DIMENSION

TANK CI, BOTTOM DRAWING NUMBER (H-2-37909)

TANK CL BOTTOM ELEVATION NUEA RISER (1)

RISER ELEVATION (Ft.) 673.8000

TANK INSIDE BOTTOM ELEVATION (Ft.) - 635.0000

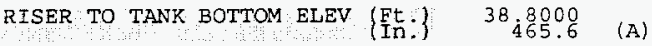

DETERMININE RERERENCE LEVEL:

$1 / 16$ GASKET @ 50\% COMPRESSION (In.) +

$0.0313 \quad$ (B)

PVC FLANGE (OPTIONAL) (In.) + 1.0000 (C)

$1 / 8$ GASKET @ $50 \%$ COMPRESSION (In.) +0.0625 (D)

BALL VALVE FLANGE TO FLANGE (In.) + 9.0000 (E)

BALL INSET DIM (FROM TOP) (In.) - 1.4700 (F)

IMMERSION DEPTH ON SOLIDS (In.) + 0 (G)

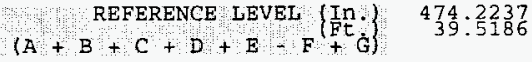




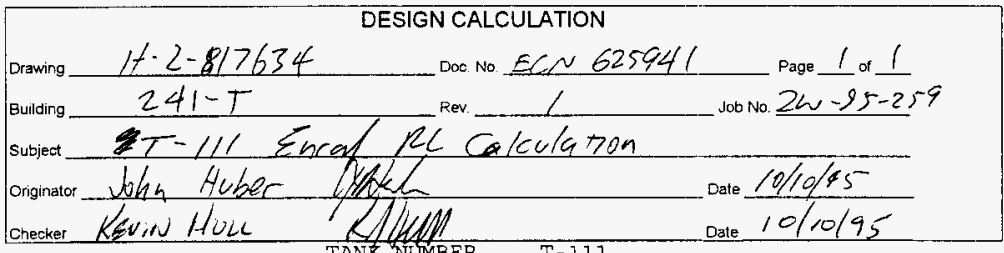

BOTTOM OF TANK TO RISER DIMENSION

DRAWING NUMBER (H-2-37909)

RISER NUMBER (4)

RISER ELEVATION (Ft.) 672.8200

TANK INSIDE BOTTOM ELEVATION (Ft.) - 634.0000

FISER TO TANK BOTTOM ELEV \{Et.\} $\begin{array}{rll}38.8200 & \\ 465.84 & \text { (A) }\end{array}$

DETERMINING REFERENCE LEVEL:

$1 / 16$ GASKET @ 50\% COMPRESSION (In.) + 0.0313 (B)

PVC FLANGE (OPTIONAL) (In.) + 1.0000 (C)

$1 / 8$ GASKET @ 50\% COMPRESSION (In.) + 0.0625 (D)

BALL VALVE ELANGE TO FLANGE (In.) + 9.0000 (E)

BALI INSET DIM (FROM TOP) (In.) - 1.4700 (F)

IMMERSION DEPTH IN SOLIDS (In.) + 0 (G)

REFERENCE LEVEL ( $\left.\begin{array}{l}\text { In } \\ \text { Ft }\end{array}\right) \quad \begin{array}{r}474.4638 \\ 39.5386\end{array}$ 


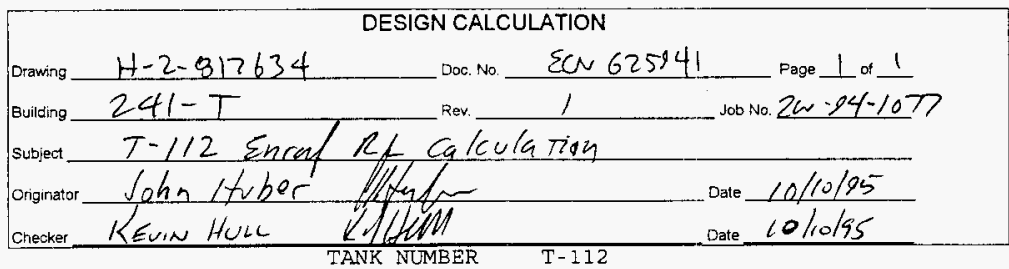

BOTTOM OF TANK TO RISER DIMENSION

DRAWING NUMBER

RISER NUMBER

(H-2-37909)

(13)

RISER ELEVATION (Ft.) 673.4700

TANK CL BOTTOM ELEVATION (Ft.) - 633.0000

RISER TO TANK BOTTOM ELEV (Ft:) $\begin{array}{rlll}40.4700 & 435.64 & \text { (A) }\end{array}$

\section{DETERMINING REFERENCE LEVEL:}

1/16 GASKET @ 50\% COMPRESSION (In.) + PVC FLANGE (OPTIONAL) (In.) +

1/8 GASKET @ 50\% COMPRESSION (In.) + BALI VALVE FLANGE TO FLANGE (In.) +

BALL INSET DIM (FROM TOP) (In.) -

IMMERSION DEPTH AT $1.05 \mathrm{Sp}$. G. + I/16 GASKET @ 50\% COMPRESSION (In.) + MULTIPORT FLG H-2-817634, ASSY $50+$ $(\mathrm{A}+\mathrm{B}+\mathrm{C}+\mathrm{D}+\mathrm{E}-\mathrm{F}+\mathrm{G}+\mathrm{H}+\mathrm{I})$ 0.0313

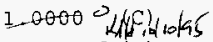
$0-0825 \circ$ (D) 9.0000

1.4700

0.2775

0.0313

1.2500

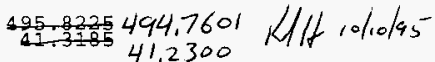

\section{* IMMERSION DEPTH CALCULATION} GOVERNING EQUATION
$=\left(4^{\star} \mathrm{Fb}\right)$
$\left(\mathrm{Sg} \mathrm{Pi}^{\star} \mathrm{D}^{\star} \star 2\right)$
$\mathrm{Fb}=$ BOUYANT FORCE = SET POINT $=$
15.0000
GRAMS
$\mathrm{Sg}=$ SPECIFIC GRAVITY OF LIQUID =
1.0500
$D=$ DISPLACER DIAMETER =
2.0000 INCHES
$\mathrm{H}=$ IMMERSION DEPTH (FROM EQUATION) $=0.7048$ CENTIMETERS 
WHC-SD-WM-CN-078

REVISION 0

THIS PAGE RESERVED FOR T-201

A-141 
WHC-SD-WM-CN-078

REVISION 0

THIS PAGE RESERVED FOR T-202

A-142 
WHC-SD-WM-CN-078

REVISION 0

THIS PAGE RESERVED FOR T-203 
THIS PAGE RESERVED FOR T-204 


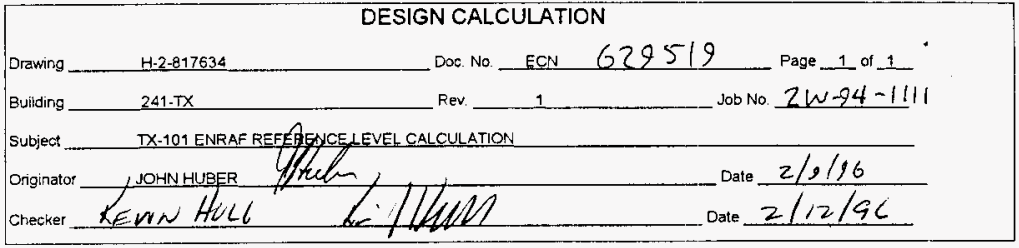

TANK NUMEER TX-101

BOTTOM OF TANK TO RISER DIMENSION

DRAWING NUMBER (H-2-37910)

RISER NUMBER

RISER ELEVATION (Ft.) 672.1300

TANK INSIDE BOTTOM ELEVATION (Ft.) - 624.7300

TANK SIDE-BOTTOM ELEVATION (FE.) RISER TO TANK BOTTOM ELEVATTON

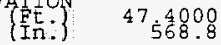

(A)

DETERMINING REFERENCE LEVEL:

1/16 GSKT \& 50\% COMPRESSION (In,) +

PVC FLANGE (OPTIONAL) (In.) +

0.0313

(B)

1/8 GSKT @ 50\% COMPRESSION (In.) +

1.0000

(C)

EXTENSION SPOOL (In.) +

0.0525

(D)

$1 / 8$ GASKET @ 50\% COMPRESSION (In.) +

.0000

BALL VALVE FLANGE TO FLANGE (In.) +

0.0625

BALI INSET DIM (FROM TOP) (In.) -

9.0000

IMMRSN DEPTH @ $1.05 \mathrm{Sp} . \mathrm{G} .(\mathrm{In})+$.

1.4700

REFERENCE LEVEL $(\mathrm{Tn}$.

589.7637

$(\mathrm{A}+\mathrm{B}+\mathrm{CH}+\mathrm{D}+\mathrm{B}-\mathrm{F}+\mathrm{G}$

* IMMERSION DEPTH CALCULATION

$H=(4 * \mathrm{Fb}) /(\mathrm{Sg} * \mathrm{FOUATION}$

$\mathrm{Fb}=$ BOUYANT FORCE $=\mathrm{SET}$ POINT $=$

15.0000 GRAMS

$\mathrm{Sg}=$ SPECIFIC GRAVITY OF IIQUID $=1.0500$

$D=$ DISPIACER DIAMETER $=2.0000$ INCHES

$H=$ IMMERSION DEPTH (FROM EQTN.) = 0.7048 CENTIMETERS 


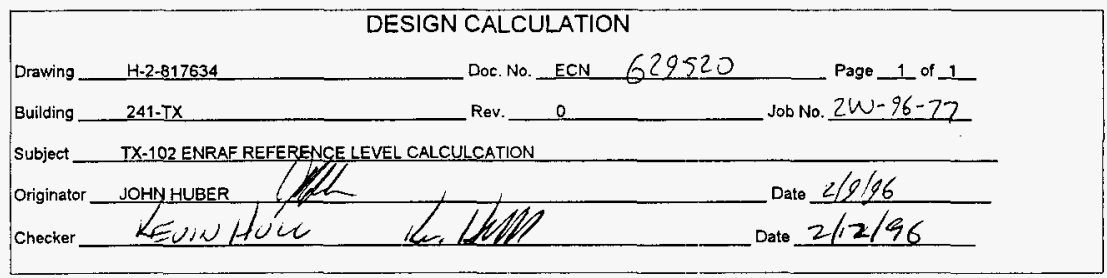

TANK NUMBER

TX- 102

BOTTOM OF TANK TO RISER DIMENSION

DRAWING NUMBER (H-2-37910)

RISER NUMBER (9A)

RISER ELEVATION (Ft.) 673.1100

TANK INSIDE BOTTOM ELEVATION (Ft.) - 623.7300

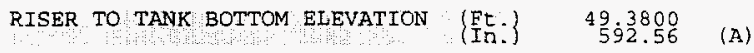

DETERMINING REEERENCE LEVEL:

$1 / 16$ GSKT @ 50\% COMPRESSION (In.) + 0.0313 (B) PVC FIJANGE (OPTIONAL) (In.) + N/A (C)

$1 / 8$ GSKT @ 50\% COMPRESSION (In.) + N/A (D)

BALL VALVE FLANGE TO ELANGE (In.) + 9.0000 (E)

BALL INSET DIM (FROM TOP) (In.) - 1.4700 (F)

IMMRSN DEPTH IN SOLIDS (In.) + 0 (G)

REFERENCE LEVEL (In.) 600.1213

$(\mathrm{A}+\mathrm{B}+\mathrm{C}+\mathrm{D}+\mathrm{E}-\mathrm{F}+\mathrm{Ft}$ 


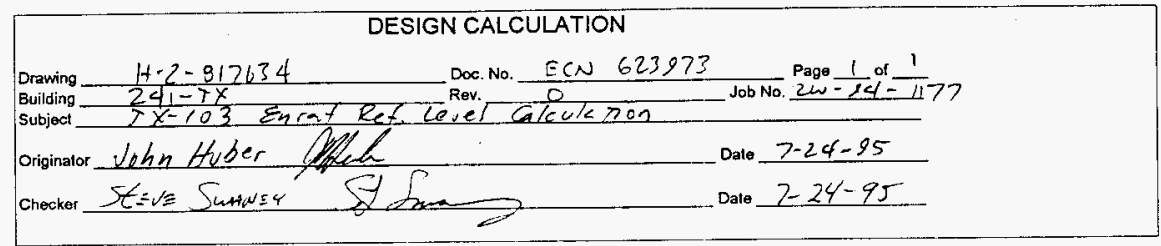

\section{TANK NUMBER TX-103 \\ BOTTOM OF TANK TO RISER DIMENSION \\ DRAWING NUMBER (H-2-37910) \\ RISER NUMBER (8) \\ RISER ELEVATION (Ft.) 671.0400
INSIDE BOTTOM ELEVATION - 622.7300 \\ TANK INSIDE BOTTOM ELEVATION - 622.7300
TANK SIDE-BOTTOM ELEVATION (Ft.) - \\ RISER TO TANK BOTTOM ELEVATION \\ $48.3100^{\circ}$ \\ $579.72 \quad$ (A)}

DETERMINING REFERENCE LEVEL:

$1 / 16$ GSKT @ 508 COMPRESSION (In.) + PVC FLANGE (OPTIONAL) (In.) + I/8 GSKT @ 508 COMPRESSION (In.) + BALL VALVE FLANGE TO FLANGE (In.) + BALL INSET DIM (FROM TOP) (In.) IMMRSN DEPTH @ $1.05 \mathrm{Sp}$. G. (In.) + $0.0313 \gamma(\mathrm{B})$ $+1.0000 \sqrt{(C)}$ $+0.0625 /$ (D) $+9.0000^{r}(\mathrm{E})$ $1.4700^{\circ}(\mathrm{F})$

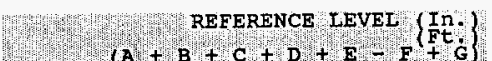

0.2775 (G) 588.6212

*IMMERSION DEPTH CALCULATION
GOVERNING EQUATION
$\mathrm{H}=(4 * \mathrm{Fb}) /\left(\mathrm{Sg} * \mathrm{Pi} * \mathrm{D}^{* * 2}\right)$
$\mathrm{Fb}=$ BOUYANT FORCE $=$ SET POINT
15.0000 GRAMS
Sg = SPECIFIC GRAVITY OF LIQUID =
1.0500
$\mathrm{D}=$ DISPLACER DIAMETER =
2.0000 INCHES
$H$ = IMMERSION DEPTH (FROM EQTN.)
0.7048 CENTIMETERS 


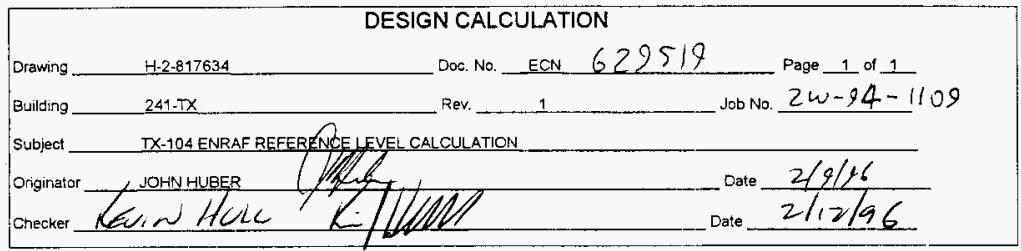

TANK NUMBER

TX- 104

BOTTOM OF TANK TO RISER DIMENSION

DRAWING NUMBER $(\mathrm{H}-2-37910)$

RISER NUMBER (B)

RISER ELEVATION (Ft.) 669.9700

TANK INSIDE BOTTOM ELEVATION (FE.) - 621.7300

TANK SIDE-BOTTOM ELEVATION (ET.) RISER TO TANK BOTTOM ELEVATION

DETERMINING REFERENCE IEVEL:

1/16 GSKT @ 50\% COMPRESSION (In.) +

0.0313 PVC FLANGE (OPTIONAI) (In.) +

1.0000

1/8 GSKT @ 50\% COMPRESSION (In.) +

0.0625

EXTENSION SPOOL (In.) + 12.0000

$1 / 8$ GASKET @ 50\% COMPRESSION (In.) + 0.0625

BALI VALVE FLANGE TO FLANGE (In.) + 9.0000

BALL INSET DIM (FROM TOP) (In.) -

1. 4700

(E)

IMMRSN DEPTH @ $1.05 \mathrm{Sp} . \mathrm{G} .(\mathrm{In})+$. 0.2775

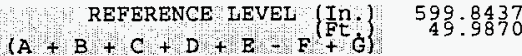

* IMMERSION DEPTH CAICULATION

$H=\left(\begin{array}{l}4 * \mathrm{Fb}) \\ \mathrm{H}\end{array}\left(\mathrm{Sg} * \mathrm{PQ} I * \mathrm{D}^{*} * 2\right)\right.$

$\mathrm{Fb}=$ BOUYANT FORCE $=$ SET POINT $=15.0000$

$\mathrm{Sg}=$ SPECIFIC GRAVITY OF LIQUID $=1.0500$

$D=$ DISPLACER DIAMETER $=2.0000$

$H=$ IMMERSION DEPTH (FROM EQTN.) = 0.7048 CENTIMETERS
GRAMS

INCHES 


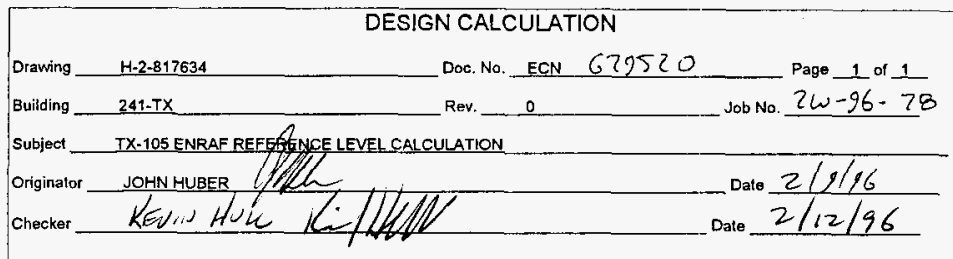

TANK NUMBER TX-105

BOTTOM OF TANK TO RISER DIMENSION

DRAWING NUMBER (H-2-37910)

RISER NUMBER (8)

RISER ELEVATION (FE.) 672.9100

TANK INSIDE BOTTOM ELEVATION (Ft.) - 624.7300

TANK SIDE-BOTTOM ELEVATION (ET.) RISER TO TANK BOTTOM ELEVATION (FE: 4877800 $\mathrm{N} / \mathrm{A}$

\section{DETERMINING REFERENCE LEVEL:}

1/16 GSKT @ 50\% COMPRESSION (In.) + 0.0313 (B)

PVC FLANGE (OPTIONAL) (In.) +1.0000 (C)

$1 / 8$ GSKT (9) 50\% COMPRESSION (In.) + 0.0625 (D)

EXTENSION SPOOL (In.) + 12.0000

I/8 GSKT (G) 50\% COMPRESSION (In.) + 0.0625

BALL VALVE FLANGE TO FLANGE (In.) +

9.0000 (E)

BALI INSET DIM (FROM TOP) (In.) -

$1.4700 \quad$ (F)

IMMRSN DEPTH IN SOLIDS (In.) +

0 (G) REFERENCEITEVET (In) $\quad \begin{array}{r}598.8462 \\ 49.9039\end{array}$ 


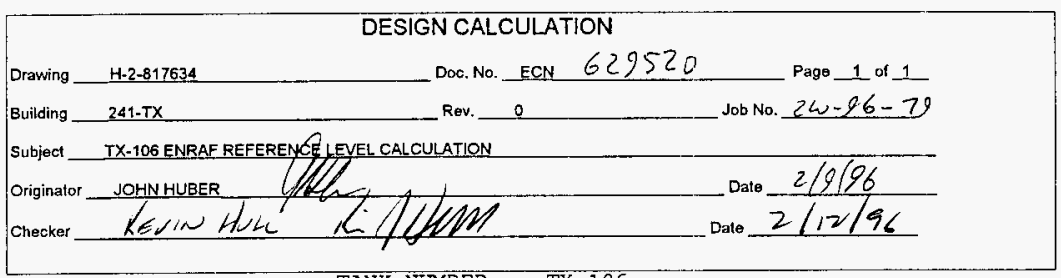

TANK NUMBER

TX-106

BOTTOM OF TANK TO RISER DIMENSION

DRAWING NUMBER (H-2-37910)

RISER NUMBER

(8)

RISER ELEVATION (Ft.) 671.9600

TANK INSIDE BOTTOM ELEVATION (FE.) - 523.7300

TANK SIDE-BOTTOM ELEVATION (Ft.) RISER TO TANK BOTTOM ELEVATION

DETERMINING RERERENCE LEVEL:

1/16 GSKT @ 50\% COMPRESSION (In.) +
0.0313
(B)

PVC FLANGE (OPTIONAI) (In.) +

1.0000

(C)

$1 / 8$ GSKT \& 50\% COMPRESSION (In.) +

0.0625

(D)

EXTENSION SPOOL (In.) +

12.0000

1/8 GSKT @50\% COMPRESSION (In.) + 0.0625

BALL VALVE FLANGE TO FLANGE (In.) +

9.0000

(B)

BALI INSET DIM (FROM TOP) (In.) -

1. 4700

IMMRSN DEPTH IN SOLIDS (In.) +

0 (G)

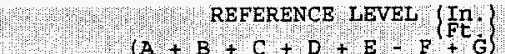

599.4463
49.9539 


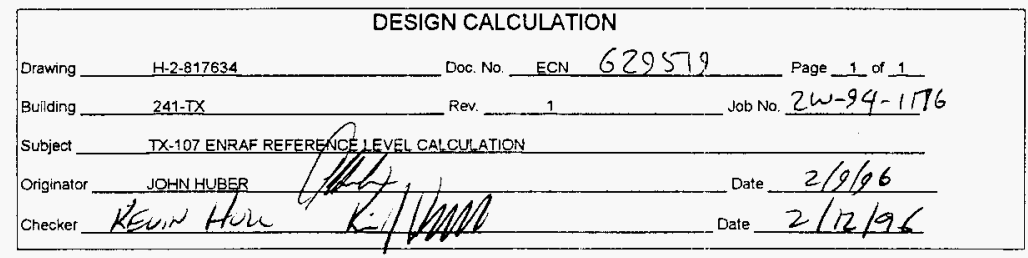

TANK NUMBER TX-107

BOTTOM OF TANK TO RISER DIMENSION

DRAWING NUMBER ( $\mathrm{H}-2-37910)$

RISER NUMBER (B)

RISER ELEVATION (Ft.) 670.9400

TANK INSIDE BOTTOM ELEVATION (Et.) - 622.7300

TANK SIDE-BOTTOM ELEVATION (ET.) -

RISER TO TANK BOTTOM ELEVATION

(FE. $\quad 48.2100$

(A)

DETERMINING REFERENCE IEVEL:

$1 / 16$ GSKT @ $50 \%$ COMPRESSION (In.) + 0.0313 (B)

FVC FLANGE (OPTIONAL) (In.) + 1.0000 (C)

$1 / 8$ GSKT @ 50\% COMPRESSION (In.) + 0.0625 (D)

EXTENSION SPOOL (In.) + 12.0000

$1 / 8$ GASKET @50\% COMPRESSION (In.) + 0.0625

BALI VALVE FLANGE TO FLANGE (In.) + 9.0000 (E)

BALL INSEI DIM (FROM TOP) (In.) - 1.4700 (F)

IMMRSN DEPTH IN SOLIDS (In.) + 0 (G)

REFERENCE LEVET ( In $) \quad \begin{aligned} & 599.2063 \\ & 49.9339\end{aligned}$ 


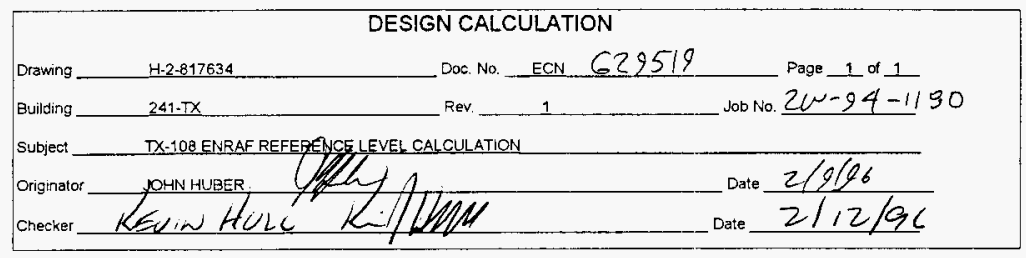

TANK NUMBER TX-108

\section{BOTTOM OF TANK TO RISER DIMENSION}

DRAWING NUMBER (H-2-37910)

RISER NUMBER (8)

RISER ELEVATION (Ft.) 659.9800

TANK INSIDE BOTTOM ELEVATION (Ft.) - 621.7300

TANK SIDE-BOTTOM ELEVATION (Ft.) RISER TO TANK BOTTOM ELEVATION (FE:)

\section{DETERMINING RERERENCE LEVEL:}

$1 / 16$ GSKT @ 50\% COMPRESSION (In.) + 0.0313 (B)

PVC FLANGE (OPTIONAL) (In.) +1.0000 (C)

$1 / 8$ GSKT @ 50\% COMPRESSION (In.) + 0.0625 (D)

EXTENSION SPOOL (In.) + 12.0000

$1 / 8$ GASKET @ 50\% COMPRESSION (In.) + 0.0625

BALL VALVE FLANGE TO FLANGE (In.) + 9.0000 (E)

BALI INSET DIM (EROM TOF) (In.) - 1.4700 (F)

IMMRSN DEPTH IN SOLIDS (In.) + 0 (G)

REFERENCE LEVEL (IDP) $\begin{array}{r}599.6863 \\ 49.9739\end{array}$ 


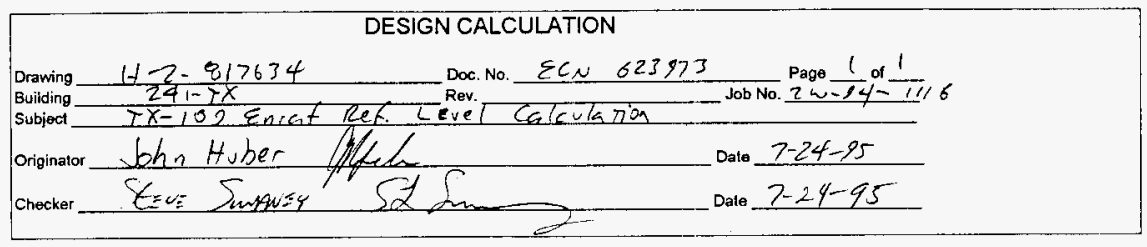

TANK NUMBER TX-109

BOTTOM OF TANK TO RISER DIMENSION

DRAWING NUMBER ( $\mathrm{H}-2-37910)$

RISER NUMBER

RISER ELEVATION (FE.)

$672.1300 \checkmark$

TANK INSIDE BOTTOM ELEVATION - $624.7300 /$

TANK SIDE-BOTTOM ELEVATION (Ft.) -

RISER TO TANR BOTTOM ELEVATION

DETERMINING REFERENCE LEVEL:
LEN

1/16 GSKT 508 COMPRESSION (In.) +

$+0.0313 r$ (B)

PVC FLANGE (OPTIONAL) (In.)

$+1.0000 /(\mathrm{C})$

$1 / 8$ GSKT a 508 COMPRESSION (In.) $+0.0625 /$ (D)

BALL VALVE FLANGE TO FLANGE (In.) + $9.0000^{\prime}$ (E)

BALL INSET DIM (FROM TOP) (In.) - 1.4700 - (F)

IMMRSN DEPTH IN SOLIDS (In.)

$+\quad$ OV (G)

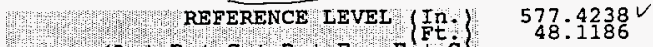

$(A+B+C+D+E-F(+\dot{G})$ 


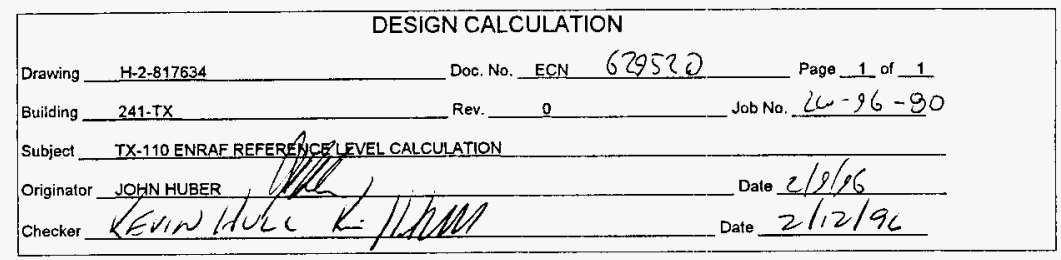

TANK NUMBER TX-110

BOTTOM OF TANK TO RISER DIMENSION

$$
\text { DRAWING NUMBER (H-2-37910) }
$$

RISER NUMBER (7)

RISER ELEVATION (Ft.) 671.2500

TANK INSIDE BOTTOM ELEVATION (Ft.) - 623.7300

TANK SIDE-BOTTOM ELEVATION (Ft.) RISER TO TANK BOTTOM ELEVATION

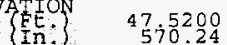

$\mathrm{N} / \mathrm{A}$

\section{DETERMINING REFERENCE LEVEL:}

$1 / 16$ GSKT @ 50\% COMPRESSION (In.) +

PVC FLANGE (OPTIONAL) (In.) +

0.0313

(B)

$1.0000 \quad(\mathrm{C})$

I/8 GSKT @ 50\% COMPRESSION (In.) + 0.0625 (II)

MULTI-PORT (In.) +14.1250

$1 / 8$ GSKT $@ 50 \%$ COMPRESSION (In.) + 0.0625

BALL VALVE FLANGE TO FLANGE (In.) + 9.0000 (E)

BAIL INSET DIM (FROM TOP) (In.) - 1.4700 (F)

IMMRSN DEPTH IN SOLIDS (In.) + 0 (G)

$$
\left(\mathrm{A}+\mathrm{B}+\mathrm{C}+\mathrm{D}+\mathrm{B}-\mathrm{F}+\mathrm{G} \text { ) } \quad \begin{array}{r}
593.0513 \\
49.4209
\end{array}\right.
$$




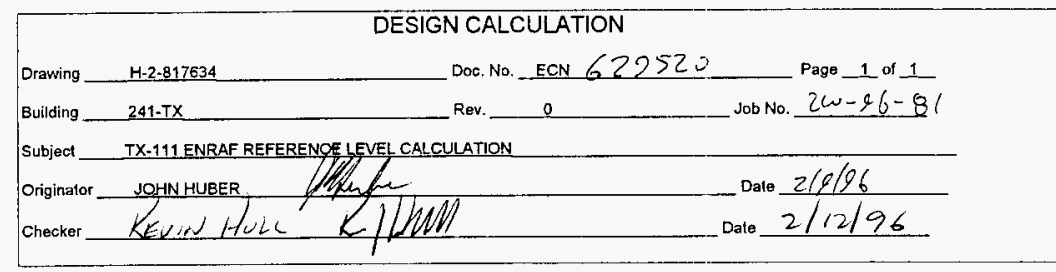

TANK NUMBER TX-111

BOTTOM OF TANK TO RISER DIMENSION

DRAWING NUMBER (H-2-37910)

RISER NUMBER

(1)

RISER ELEVATION (Ft.) 670.1400

TANK INSIDE BOTTOM ELEVATION (Ft.) - 622.7300

TANK SIDE-BOTTOM ELEVATION (Ft.) RISER TO TANK BOTTOM ELEVATION

(F) $\begin{array}{r}47.4100 \\ 5.68 .92\end{array}$

$\mathrm{N} / \mathrm{A}$

\section{DETERMINING REFERENCE LEVEL:}

$1 / 16$ GSKT @ 50\% COMPRESSION (In.) + PVC FLANGE (OPTIONAL) (In.) +
0.0313
(B)
1.0000

1/8 GSKT@ 50\% COMPRESSION (In.) +

(C)

EXTENSION SPOOL (In.) +

0.0625

(D)

1/8 GSKT @ 50\% COMPRESSION (In.) +

12.0000

BALI VALVE FLANGE TO FLANGE (In.) +

0.0625

BALL INSET DIM (FROM TOP) (In.) -

9.0000

IMMRSN DEPTH IN SOLIDS (In.) +

1.4700

THOYOU REFERENCB ILEVEL ( Tn.)

$(\mathrm{A}, \mathrm{B}+\mathrm{C}+\mathrm{D}+\mathrm{E}-\mathrm{F}+\mathrm{G}\}$

589.6063
49.1339 


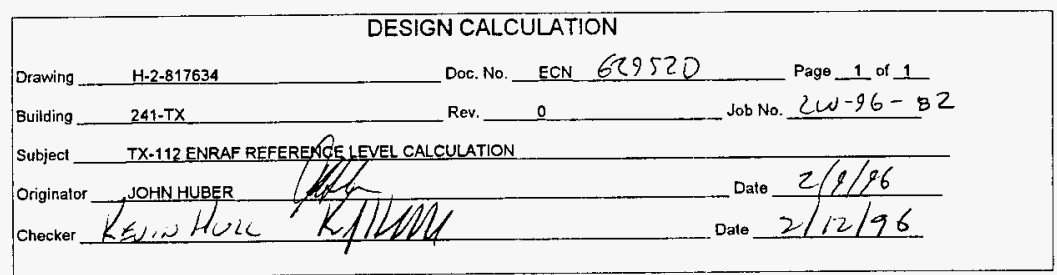

TANK NUMBER

$\mathrm{TX}-112$

BOTTOM OF TANK TO RISER DIMENSION

DRAWING NUMBER ( $\mathrm{H}-2-37910)$

RISER NUMBER (1)

RISER ELEVATION (Ft.) 669.1800

TANK INSIDE BOTTOM ELEVATION (Ft.) - 621.7300

TANK SIDE-BOTTOM ELEVATION (Ft.) RISER TO TANK BOTTOM EIJEVATION

Fin. $\quad 47.4500$

(A)

\section{DETERMINING REFERENCE LEVEL:}

$1 / 16$ GSKT @ 50\% COMPRESSION (In.) + 0.0313 (B)

PVC FLANGE (OPTIONAL) (In.) + 1.0000 (C)

$1 / 8$ GSKT (B) $50 \%$ COMPRESSION (In.) +0.0625 (D)

EXTENSION SPOOL (In.) + 36.0000

$1 / 8$ GSKT @ 50\% COMPRESSION (In.) + 0.0625

BALL VAIVE FLANGE TO FLANGE (In.) + 9.0000 (E)

BALL INSET DIM (FROM TOP) (In.) - 1.4700 (E)

IMMRSN DEPTH IN SOLIDS (In.) + 0 (G)

$(\mathrm{A}+\mathrm{B}+\mathrm{C}+\mathrm{D}+\mathrm{BH}-\mathrm{F}+\mathrm{G}) \quad \begin{array}{r}614.0862 \\ 51.1739\end{array}$ 


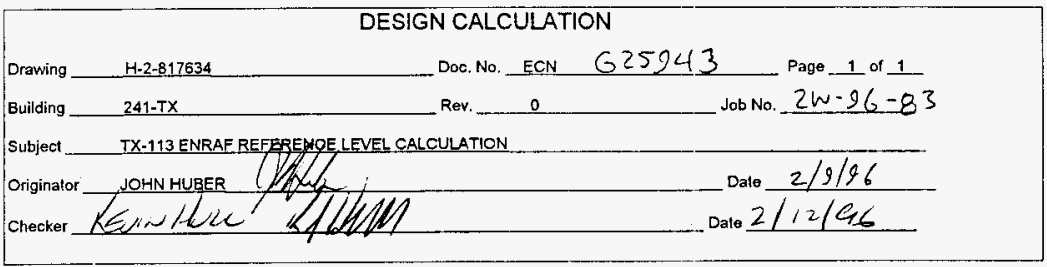

TANK NUMBER TX-113

BOTTOM OF TANK TO RISER DIMENSION

DRAWING NUMBER (H-2-37910)

RISER NUMBER (1)

RISER ELEVATION (Ft.) 671.9700

TANK INSIDE BOTTOM ELEVATION (FE.) - 624.7300

TANK SIDE-BOTTOM ELEVATION (Ft.) RISER TO TANK BOTTOM ELEVATION TFE: $\quad 47.2400$

(A)

DETERMINING REPERENCE LEVEL:

$1 / 16$ GSKT @ 50\% COMPRESSION (In.) +

PVC FLANGE (OPTIONAL) (In.) +

0.0313 (B)

1/8 GSKT @50\% COMPRESSION (In.) +

1.0000 (C)

BAIL VALVE FLANGE TO FLANGE (In.) +

0.0625 (D)

BALL INSET DIM (FROM TOP) (In.) -

9.0000 (E)

IMMRSN DEPTH IN SOLIDS (In.) +

1.4700 (F)

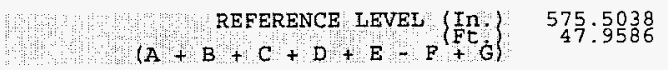

0 (G)




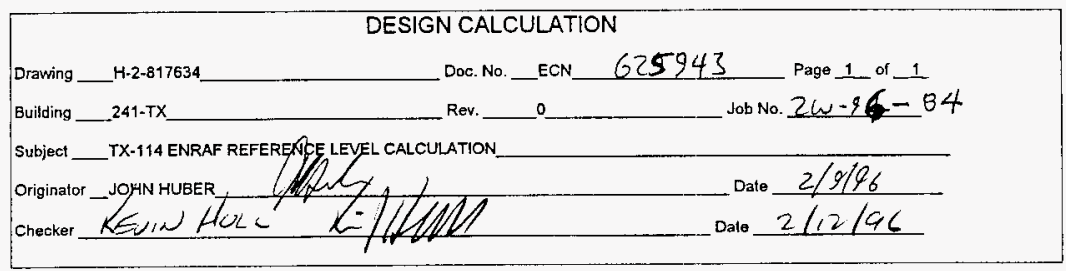

TANK NUMBER

$\mathrm{TX}-114$

BOTTOM OF TANK TO RISER DIMENSION

DRAWING NUMBER (H-2-37910)

RISER NUMBER

RISER ELEVATION (Ft.) 671.1400

TANK INSIDE BOTTOM ELEVATION (FE.) - 623.7300

TANK SIDE-BOTTOM ELEVATION (Ft.) RISER TO TANK BOTTOM ELEVATION IFE: $\quad 47.4100$

(A)

\section{DETERMINING REFERENCE LEVEL:}

1/16 GSKT@50\% COMPRESSION (In.) +

0.0313 (B)

PVC FLANGE (OPTIONAL) (In.) +

$1.0000 \quad$ (C)

1/8 GSKT @ 50\% COMPRESSION (In.) +

0.0625 (D)

BALL VALVE FLANGE TO FLANGE (In.) +

$9.0000 \quad(\mathrm{E})$

BALL INSET DIM (FROM TOP) (In.) -

1.4700 (F)

IMMRSN DEPTH IN SOLIDS (In.) +

0 (G)

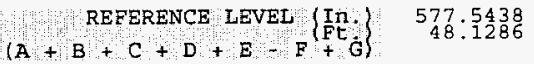




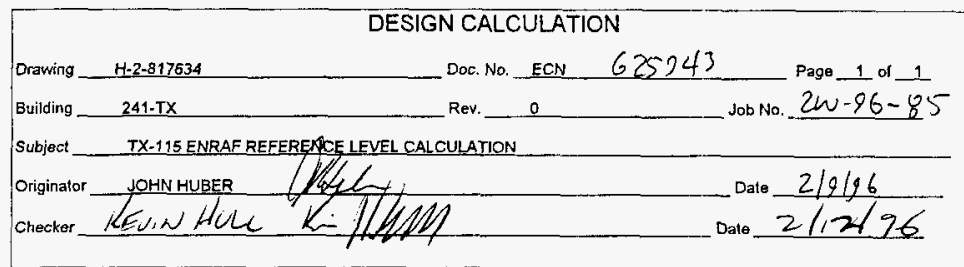

$$
\text { TANK NUMBER TX-115 }
$$

BOTIOM OF TANK TO RISER DIMENSION

DRAWING NUMBER

RISER NUMBER

$(H-2-37910)$

RISER ELEVATION (Ft.) 670.1500

TANK INSIDE BOTTOM ELEVATION (Ft.) - 622.7300

TANK SIDE-BOTTOM ELEVATION (Ft.) RISER TO TANK BOTTOM ELEVATION

\{FE: $\quad 47.4200$

(A)

DETERMINING REFERENCE LEVEL:

$1 / 16$ GSKT @ 50\% COMPRESSION (In.) + 0.0313 (B)

FVC FLANGE (OPTIONAL) (In.) +1.0000 (C)

$1 / 8$ GSKT \& 50\% COMPRESSION (In.) + 0.0625 (D)

BALL VALVE FLANGE TO FLANGE (In.) + 9.0000 (E)

BALL INSET DIM (FROM TOP) (In.) - 1.4700 (F)

IMMRSN DEPTH IN SOLIDS (In.) + 0 (G)

REFERENCB LEVEL (

$(\mathrm{A}+\mathrm{B}+\mathrm{C}+\mathrm{D}+\mathrm{B}-\mathrm{B}+\mathrm{Ft} \dot{\mathrm{G}}\} \quad 48.1385$ 


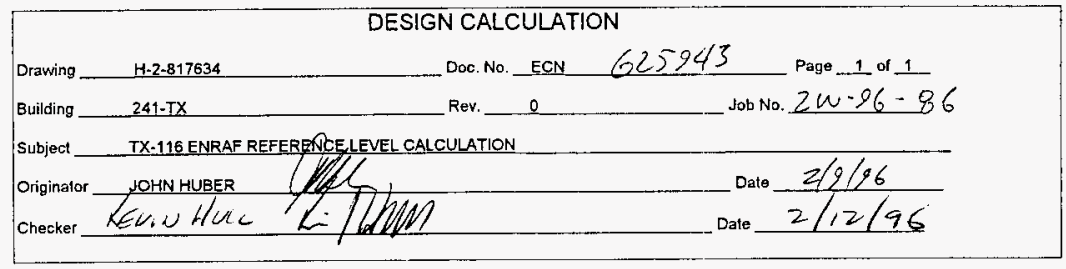

TANK NUMBER TX-116

BOTTOM OF TANK TO RISER DIMENSION

DRAWING NUMBER (H-2-37910)

RISER NUMBER (1)

RISER ELEVATION (Ft.) 672.0300

TANK INSIDE BOTTOM ELEVATION (Ft.) - 624.7300

TANK SIDE-BOTTOM ELEVATION (Ft.) RISER TO TANK BOTTOM ELEVATION

(FE:

$\mathrm{N} / \mathrm{A}$

\section{DETERMINING REEERENCE LEVEL:}

1/16 GSKT @ 50\% COMPRESSION (In.) +

PVC FLANGE (OPTIONAL) (In.) +

47.3000
567.6

(A)

/8 GSKT @ 50\% COMPRESSION (In.) +

BALL VALVE FLANGE TO ELANGE (In.) +

BALL INSET DIM (FROM TOP) (In.) -

0.0313

(B)

1.0000

IMMRSN DEPTH IN SOLIDS (In.) +

0.0625 (D)

9.0000 (E)

1.4700 (F)

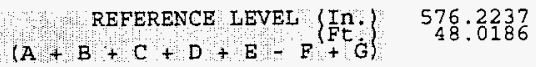




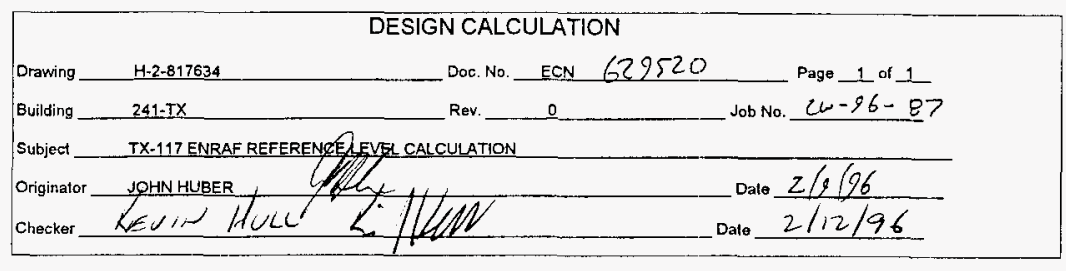

BOTTOM OF TANK TO RISER DIMENSION

DRAWING NUMBER (H-2-37910)

RISER NUMBER (11A)

RISER ELEVATION (Ft.) 670.3700

TANK INSIDE BOTTOM ELEVATION (Ft.) - 623.7300

TANK SIDE-BOTTOM ELEVATION (Ft.) RISER TO TANK BOTTOM ELEVATION

(FE: $\begin{array}{r}46.6400 \\ \text { Int: }\end{array}$

(A)

DETERMINING REFERENCE LEVEL:

1/16 GSKT @ 50\% COMPRESSION (In.) + 0.0313 (B)

PVC FLANGE (OPTIONAL) (In.) + 1.0000 (C)

1/8 GSKT @ 50\% COMPRESSION (In.) + 0.0625 (D)

EXTENSION SPOOL (In.) + 12.0000

1/8 GSKT @ 50\% COMPRESSION (In.) + 0.0625

BALL VALVE FLANGE TO FLANGE ( In.) + 9.0000 (E)

BAIL INSET DIM (FROM TOP) (In.) - 1.4700 (F)

IMMRSN DEPTH IN SOLIDS (In.) + 0 (G)

REFERENCE LEVEL \{ $\{\mathrm{IF}$.
580.3663
48.3639 


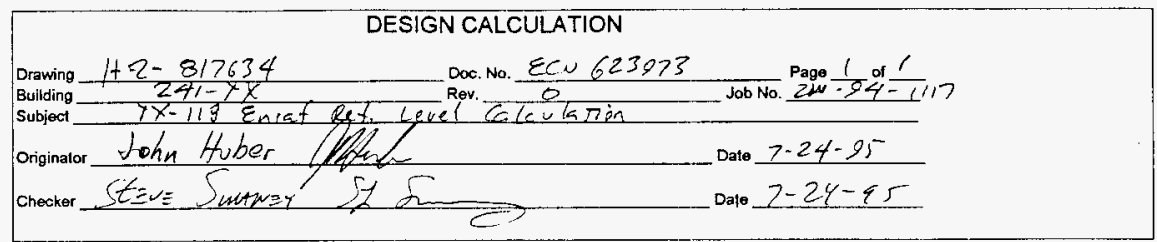

TANK NUMBER TX-118

BOTPOM OF TANK TO RISER DIMENSION

DRAWING NUMBER (H-2-37382)

RISER NUMBER

RISER ELEVATION (Ft.) $670.2100 /$

TANK INSIDE BOTTOM ELEVATION - $622.7300 \checkmark$

TANK SIDE-BOTTOM ELEVATION (Ft.) -

RISER TO TANK BOTTOM ELEVATION
47.4800
(In.)

DETERMINING REFERENCE LEVEL:
DETH

N/A

$1 / 16$ GSKT @ $50 \%$ COMPRESSION (In.) +

PVC FLANGE (OPTIONAL) (In.) +

$1 / 8$ GSKT \& 50\% COMPRESSION (In.) + BALL VALVE FLANGE TO FLANGE (In.) + BALL INSET DIM (FROM TOP) (In.) IMMRSN DEPTH @ $1.05 \mathrm{sp} . \mathrm{G}$. (In.)

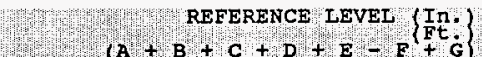

$+\quad 0.0313<(\mathrm{B})$

$1.0000 /$ (C)

$0.0625 \checkmark$ (D)

$9.0000 /$ (E)

-1.4700 (F)

+0.2775 (G)

* IMPERSION DEPTH CALCULATION

578.6612

GOVERNING EQUATION

$\mathrm{H}=(4 * \mathrm{Fb}) /\left(\mathrm{Sg} \mathrm{Pi}^{*} \mathrm{D} * \star 2\right)$

$\mathrm{Fb}=$ BOUYANT FORCE $=$ SET POINT $=15.0000$ GRAMS

$\mathrm{Sg}=$ SPECIFIC GRAVITY OF LIQUID $=1.0500$

$\mathrm{D}=$ DISPLACER DIAMETER $=2.0000$ INCHES

H = IMMERSION DEPTH (FROM EQTN.) = 0.7048 CENTIMETERS 


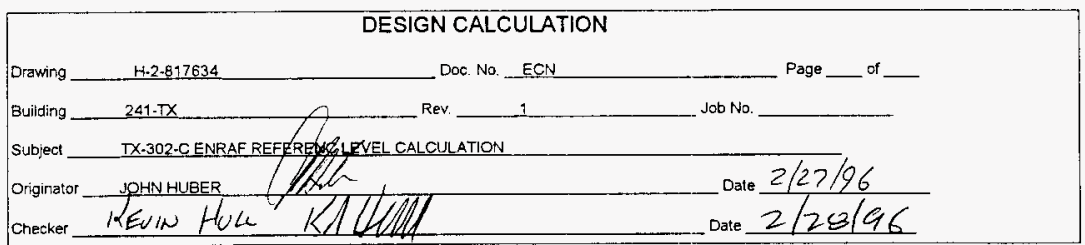

Note: Upon placing the Enraf into service using the Rev 0 Reference Level, it was a level of 1 " was obtained as opposed to 34 " - the last known FIC level. It was decided that the reference drawings used to calculate the original $\mathrm{RL}$ were wong. A secondary method for determining RL is to use the old FIC RL and back-calculate the top-of-ball valve level (the $R L$ ). This method is used here.

TANK NUMBER TX-302-C

OLD FIC REFERENCE LEVEI (In.) 466.6000

DIST FROM RISER FLG TO FIC REF. POINT (In.) - 33.2500

BALL VAIVE LENGTH (In.) + H 9.0000

BALL VALVE INSET DIM. (In.) $\%=1.4700$

REFERENCE LEVEL $=440.8800$ 


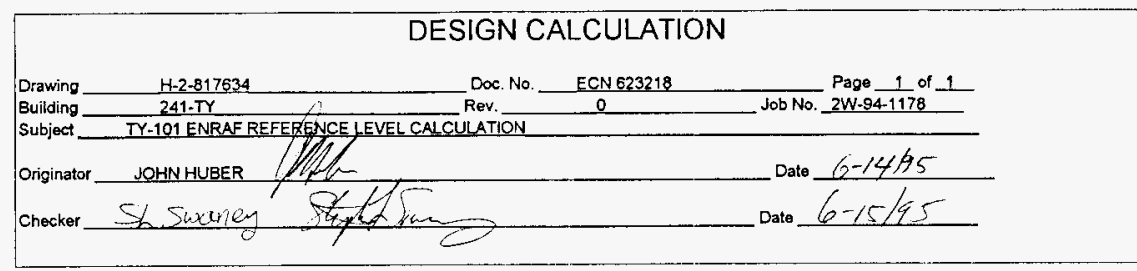

$$
\text { TANK NUMBER TY-101 }
$$

BOTTOM OF TANK TO RISER

DRAWING NUMBER (H-2-37381)

RISER NUMBER

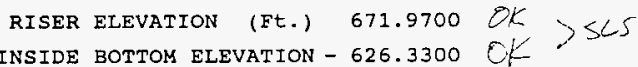

TANK INSIDE BOTTOM ELEVATION -
TANK SIDE-BOTTOM ELEVATION -

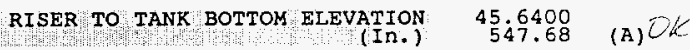

$\mathrm{N} / \mathrm{A}$

DETERMINING REFERENCE IEVEL:

1/16 GASKET a $50 \%$ COMPRESSION +

0.0313 (B) $0 k$

PVC FLANGE (OPTIONAL) (In.) +

1.0000 (c) $C$

$1 / 8$ GASKET \& 508 COMPRESSION +

0.0625

(D) $O C$

BALL VALVE FLANGE TO FLANGE +

BALL INSET DIM (FROM TOP) -

9.0000

(E) $O K$

IMMERSION DEPTH IN SOLIDS +

1.4700

- (G) $O K$ MEASURED 


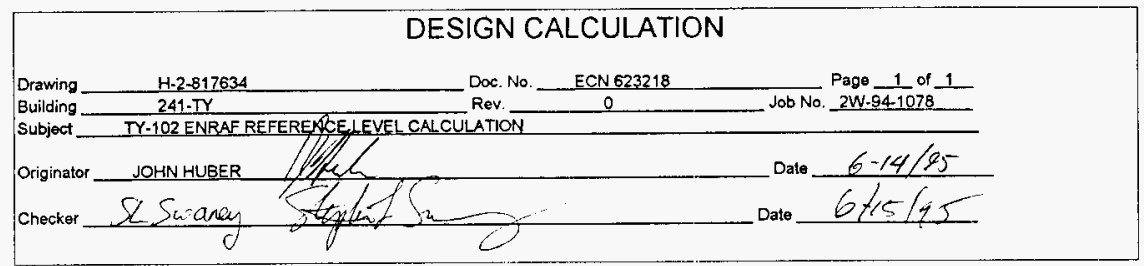

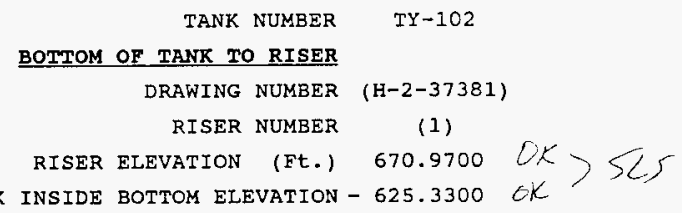

TANK SIDE-BOTTOM ELEVATION $N / A$

RISER TO TANK BOTTOM ELEVATION RISER PO TANR: BOTYON ELEVATION)

DETERMINING REFERENCE LEVEL:

$1 / 16$ GASKET @ 508 COMPRESSION + PVC FLANGE (OPTIONAL) (In.) + $1 / 8$ GASKET \& 508 COMPRESSION + BALL VALVE FLANGE TO FLANGE +

BALL INSET DIM (FROM TOP) IMMERSION DEPTH AT $1.05 \mathrm{sp.} \mathrm{G.+}$

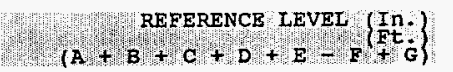

\section{* IMMERSION DEPTH CALCULATION}

GOVERNING EQUATION

$\mathrm{H}=(4 * \mathrm{Fb}) /(\mathrm{Sg} * \mathrm{Pi} * \mathrm{D} * * 2)$

$\mathrm{Fb}=$ BOUYANT FORCE $=$ SET POINT $=15.0000$

$\mathrm{Sg}=$ SPECIFIC GRAVITY OF LIQUID =

$$
D=\text { DISPLACER DIAMETER = }
$$

1.0500

2.0000

IMMERSION DEPTH (FROM EQUATION) =
0.0313 (B) $Q$

$1.0000 \quad$ (C) $O K$

0.0625 (D) $O C$

9.0000 (E) OK NEW BALL VALVE PER H-2-817634.

1.4700 (F)K PN 48, INSET DIMENSION FIELD

0.2775 (G)OK MEASURED

556.5812

$46.3818 \quad O C-5 L-5$ 

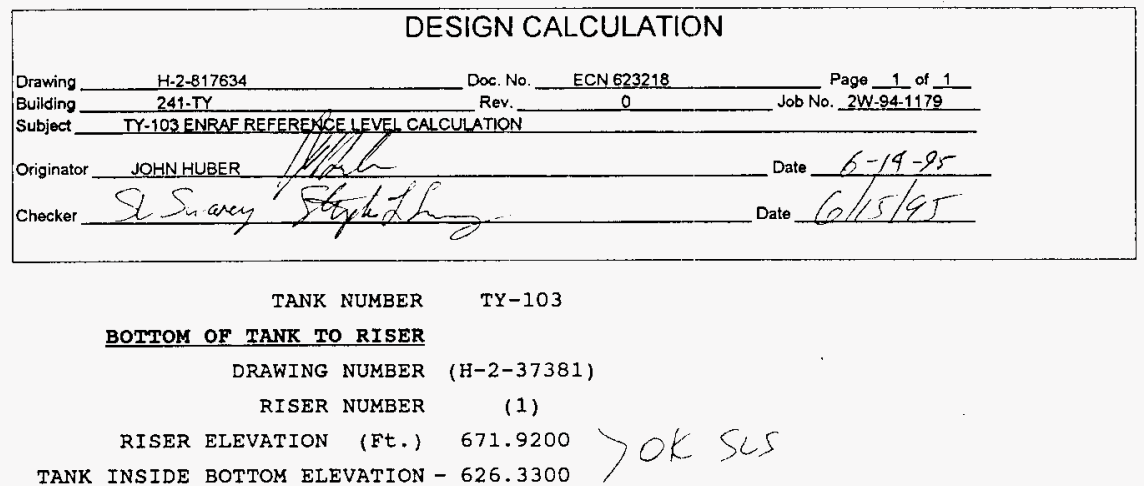

TANK INSIDE BOTTOM ELEVATION - 626.3300

TANK SIDE-BOTTOM ELEVATION N/A

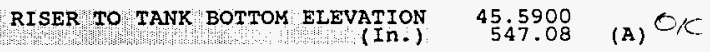

DETERMINING REFERENCE IEVEL:

1/16 GASKET (C 50\% COMPRESSION + 0.0313

(B) orc

PVC FLANGE (OPTIONAL) (In.) +

1.0000

(C) $O K$

1/8 GASKET \& 502 COMPRESSION +

0.0625

(D) $\mathrm{eic}$.

BALL VALVE FLANGE TO FLANGE +

9.0000

(E) $O K$

BAIL INSET DIM (FROM TOP) -

1.4700

IMMERSION DEPTH IN SOLIDS +

0

(F) OK PIN 48, INSET DIMENSION FIELD

(G)

REFERENCE LEVEL (In.) 555.7037

46.3086 OK-SCS 

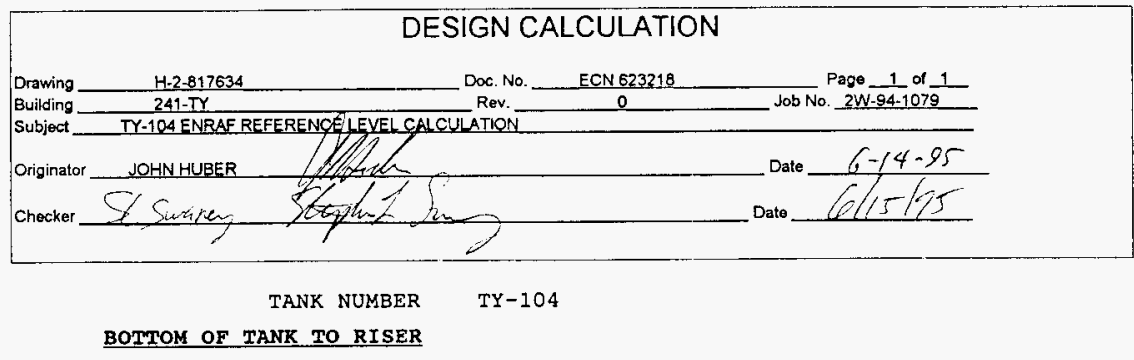

DRAWING NUMBER (H-2-37381)

RISER NUMBER

RISER ELEVATION (Ft.) 670.9700

TANK INSIDE BOTTOM ELEVATION - 625.3300 >OK - SCS

TANK SIDE-BOTTOM ELEVATION -

N/A

RISER TO TANK BOTTOM ELEVATION 45.6400

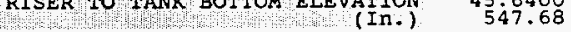

(A) $C K$

DETERMINING REFERENCE LEVET:

$1 / 16$ GASKET @ 50\% COMPRESSION +

0.0313

(B) $O K$

PVC FLANGE (OPTIONAL) (In.) +

1.0000

(C) $O K$

$1 / 8$ GASKET E $50 \%$ COMPRESSION +

0.0625

(D) OK

BALL VALVE FLANGE TO FLANGE +

9.0000

(E) OK NEW BALL VALVE PER H-2-817634,

BALL INSET DIM (FROM TOP) -

1.4700

(F) OK PNN 48, INSET DIMENSION FIELD

IMMERSION DEPTH AT $1.05 \mathrm{sp.} \mathrm{G.+}$

0.2775 MEASURED

1) $\left(\mathrm{A}+\mathrm{B}+\mathrm{C}+\mathrm{D}+\mathrm{B}-\mathrm{P}\left(\frac{\mathrm{In}}{\mathrm{G}}\right)\right.$

^IMMERSION DEPTH CALCULATION

556.5812

(G)OK

46.3818

GOVERNING EQUATION
$\mathrm{H}=(4 * \mathrm{Fb}) /\left(\mathrm{Sg} \mathrm{g}^{*} \mathrm{i} * \mathrm{D}^{\star *} 2\right)$

$\mathrm{Fb}=$ BOUYANT FORCE $=$ SET POINT $=$

15.0000

GRAMS

$\mathrm{Sg}=$ SPECIFIC GRAVITY OF LIQUID =

1.0500

$\mathrm{D}=$ DISPLACER DIAMETER =

2.0000

INCHES

IMMERSION DEPTH (FROM EQUATION) =

0.7048
0.2775

CENTIMETERS

$a c-s c 5$ 


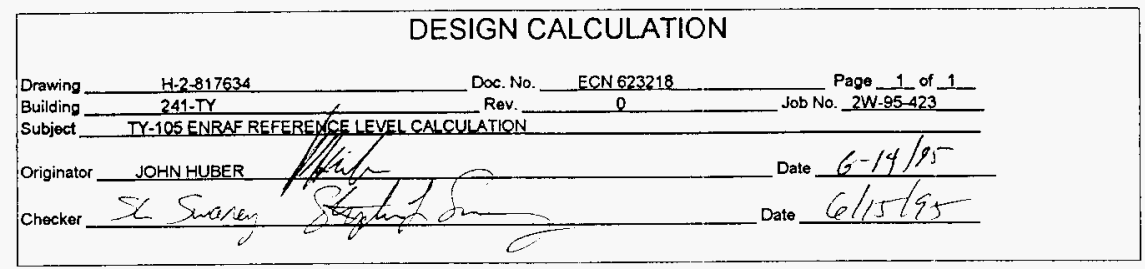

TANK NUMBER

TY-105

BOTTOK OF TANK TO RISER

DRAWING NUMBER (H-2-37381)

RISER NUMBER

(1) 2 Q4. / 152.5

RISER ELEVATION (Ft.)

TANK INSIDE BOTTOM ELEVATION $-626.3300>0 K-5$

TANK SIDE-BOTTOM ELEVATION $\mathrm{N} / \mathrm{A}$ RISER TO TANK BOTTOM ELEVATION RISER TO TANR BOTHON ELEVATI (In.) 45.6200 45.6200
547.44

(A) O/C

DETERMINING REFERENCE LEVEL:

1/16 GASKET @ 508 COMPRESSION +

0.0313

(B). $O \dot{C}$

PVC FLANGE (OPTIONAL) (In.) +

0.0000 REPLACING MT,

$1 / 8$ GASKET \& 508 COMPRESSION +

0.0000

(C) NO PVC LINER OK

BALL VALVE FLANGE TO FLANGE + 9.0000

(D) $O$

BALL INSET DIM (FROM TOP) IMMERSION DEPTH AT IN SOLIDS + 1. 4700

(E) $Q$ NEW BALL VALVE PER H-2-817634, (F) ZK PN 48, INSET DIMENSION FIELD 0 (G) 


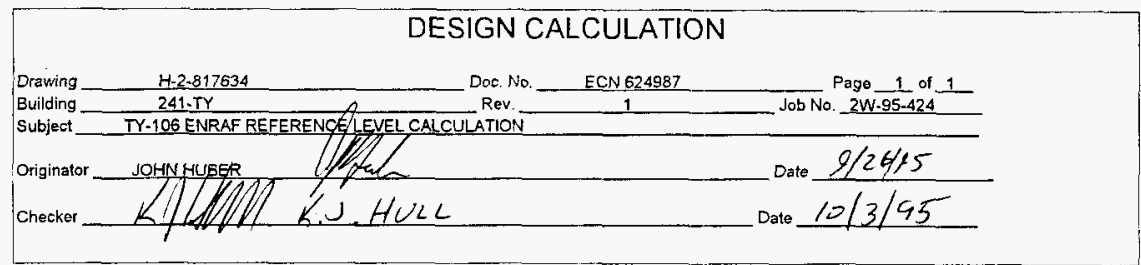

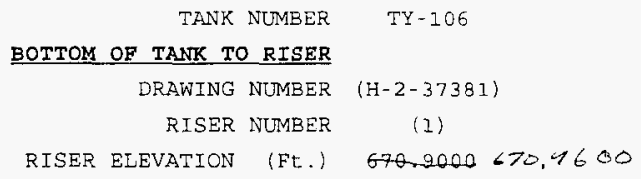

TANK INSIDE BOTTOM ELEVATION - 625.3300

TANK SIDE-BOTTOM ELEVATION RISER TO TANK BOTTOM ELEVATION

DETERMINING REFERENCE LEVEL:

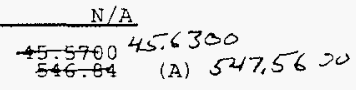

1/16 GASKET @ 50\% COMPRESSION + 0.0313

(B)

PVC FLANGE (OPTIONAL) (In.) + 0.0000

BLANK FLANGE,

1/8 GASKET@50\% COMPRESSION +

0.0000

(C) NO PVC LINER

BALL VALVE FLANGE TO FLANGE +

9.0000

(D)

BALI INSET DIM (FROM TOR) -

1.4700

(E)

(F)

NEW BALL VALVE PER H-2-817634.

IMMERSION DEPTH A'T IN SOLIDS +

REEERENCE LEVEL (In.)

$(A+B+C+D+E-F+G)$

$\frac{554.4012}{46.2001} \begin{gathered}5551213 \\ 46,2601\end{gathered}$ 
THIS PAGE RESERVED FOR U-101 


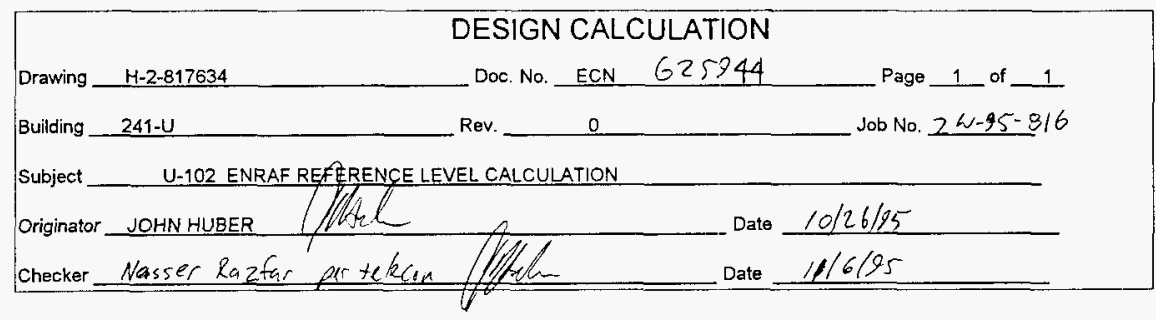

TANK NUMBER U-102

BOTTOM OF TANK TO RISER DIMENSION

DRAWING NUMBER (H-2-37381)

RISER NUMBER

(8)

RISER ELEVATION (Ft.) 665.8500

TANK CL BOTTOM ELEVATION (Ft.) - 627.0000

RISER TO TANK BOTTOM DIMENSION (Ft.) $\begin{array}{r}38.8500 \\ 466.2\end{array}$

\section{DETERMINING REFERENCE IEVEL:}

1/16 GASKET @ 50\% COMPRESSION (In.) +

0.0313 (B)

PVC FLANGE (OPTIONAL) (In.) +

1.0000 (C)

1/8 GASKET @ 50\% COMPRESSION (In.) +

0.0625 (D)

BALL VALVE FLANGE TO FLANGE (In.) +

9.0000 (E)

BALL INSET DIM (FROM TOP) (In.) -

1.4700 (F)

IMMERSION DEPTH AT $1.05 \mathrm{Sp} . \mathrm{G} .(\mathrm{In})+$.

0.2775

\section{$(\mathrm{A}+\mathrm{B}+\mathrm{C}+\mathrm{D}+\mathrm{E}-\mathrm{F}+\mathrm{G}\}$}

475.1012
39.5918

\section{* IMMERSION DEPTH CALCULATION}

GOVERNING EQUATION

$\mathrm{H}=(4 * \mathrm{Fb}) /\left(\mathrm{Sg}^{\star} \mathrm{Pi} \star \mathrm{D} \star \star 2\right)$

$\mathrm{Fb}=$ BOUYANT FORCE $=$ SET FOINT $=15.0000$ GRAMS

$S g=$ SPECIFIC GRAVITY OF LIQUID =

1.0500

$D=$ DISPLACER DIAMETER =

2.0000 INCHES

$H=$ IMMERSION DEPTH (FROM EQUATION $)=$

0.7048 CENTIMETERS

0.2775 INCH 


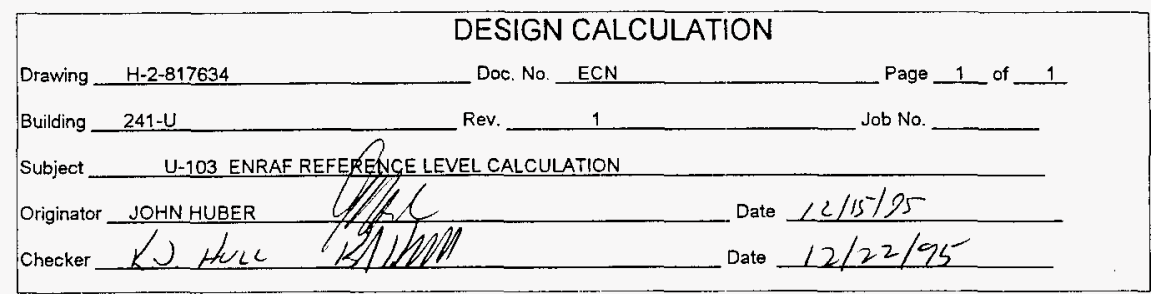

TANK NUMBER U-103

BOTTOM OF TANK TO RISER DIMENSION

DRAWING NUMBER (H-2-37381)

RISER NUMBER (8)

RISER ELEVATION (Ft.) 664.9000

TK CENTERLINE BOTTOM ELEV. (Ft.) - 526.0000

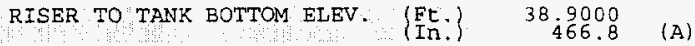

DETERMINING REEERENCE LEVEL:

$1 / 16$ GASKET @ 50\% COMPRESSION (In.) + 0.0313 (B)

PVC FLANGE (OPTIONAL) (In.) +1.0000 (C)

$1 / 8$ GASKET @ 50\% COMPRESSION (In.) + 0.0625 (D)

BALI VALVE FLANGE TO FLANGE (In.) + 9.0000 (E)

BALL INSET DIM (FROM TOP) (In.) - 1.2100 (F)

IMMERSION DEPTH AT $1.05 \mathrm{Sp}$. G. (In.) + 0.2775 (G)

$4\left(\mathrm{~A}+\mathrm{B}+\mathrm{C}+\mathrm{D}+\mathrm{B}-\mathrm{F}\{\mathrm{Ft} \dot{\mathrm{G}}\} \quad \begin{array}{r}475.9612 \\ 39.6634\end{array}\right.$

* IMMERS ION DEPTH CALCULATION

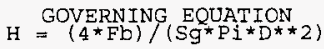

$\mathrm{Fb}=$ BOUYANT FORCE $=$ SET POINT $=15.0000$ GRAMS

$\mathrm{Sg}=$ SPECIFIC GRAVITY OF LIQUID $=1.0500$

$D=$ DISPLACER DIAMETER $=2.0000$ INCHES

$\mathrm{H}=$ IMMERSION DEPTH (FROM EQUATION) $=0.7048$ CENTIMETERS 
WHC-SD-WM-CN-078

REVISION 0

THIS PAGE RESERVED FOR U-104

A-173 


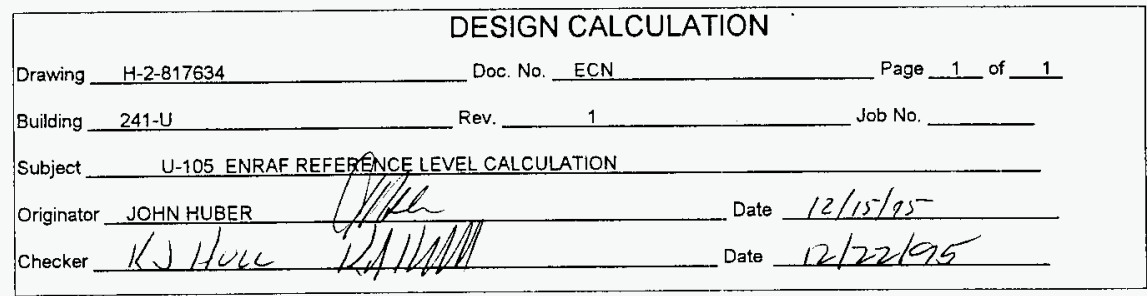

TANK NUMBER U-105

BOTTOM OF TANK TO RISER DIMENSION

DRAWING NUMBER (H-2-37381)

RISER NUMBER (8)

RISER ELEVATION (Ft.) 665.9500

TANK CL BOTTOM ELEV. (Ft.) - 627,0000

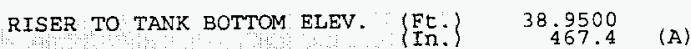

DETERMINING REFERENCE LEVEL:

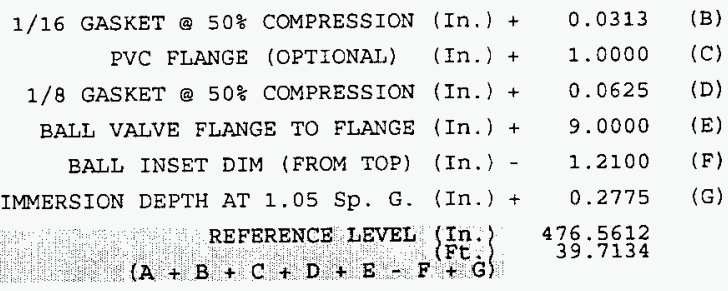

* IMMERSION DEPTH CALCULATION

GOVERNING EQUATION

$\mathrm{H}=\left(4^{\star} \mathrm{Fb}\right) /\left(\mathrm{Sg} \mathrm{Pi}^{\star} \mathrm{D}^{\star \star} 2\right)$

$\mathrm{Fb}=$ BOUYANT FORCE $=$ SET POINT $=15.0000$ GRAMS

$\mathrm{Sg}=$ SPECIFIC GRAVITY OF LIQUID $=1.0500$

$D=$ DISPLACER DIAMETER $=2.0000$ INCHES

$\mathrm{H}=$ IMMERSION DEPTH (FROM EQUATION) $=0.7048$ CCENTIMETERS 


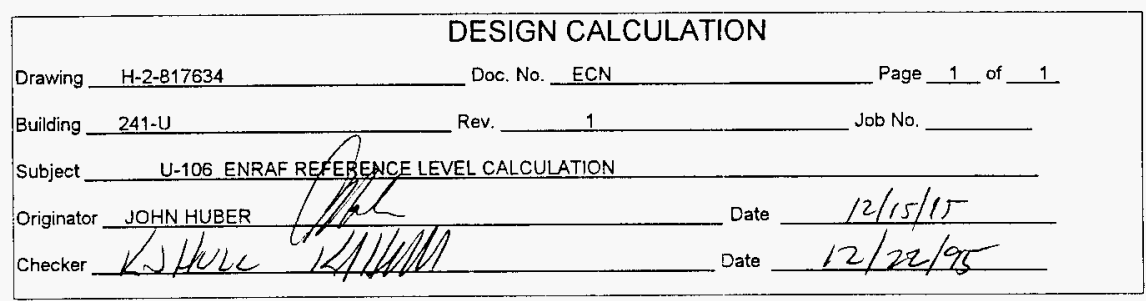

$$
\text { TANK NUMBER U-106 }
$$

BOTTOM OF TANK TO RISER DIMENSION

DRAWING NTMBER

$(\mathrm{H}-2-37381)$

RISER NUMBER

(8)

RISER ELEVATION (Ft.) 664.9300

TANK CL BOTTOM ELEV. (Ft.) - 626.0000

RISER TO TANK BOTTOM ELEV. (FE.\} $\begin{array}{r}38.9300 \\ 467.16\end{array}$

(A)

DETERMINING REFERENCE LEVEL:

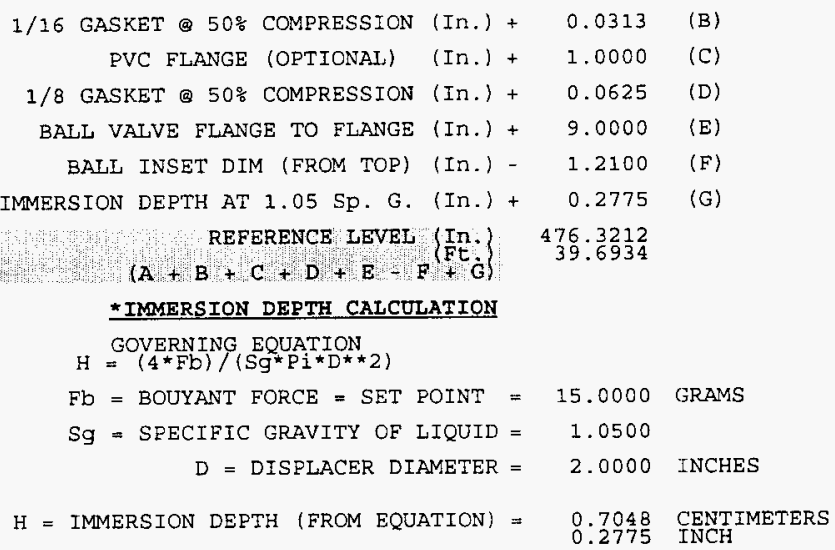




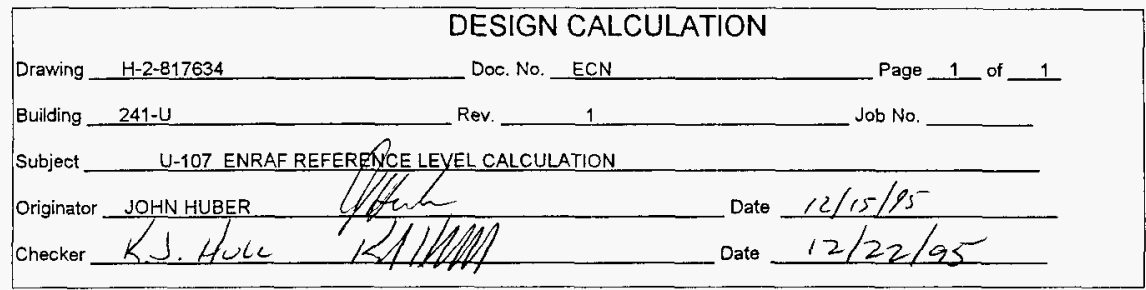

TANK NUMBER U-107

BOTTOM OF TANK TO RISER DIMENSION

DRAWING NUMBER ( $\mathrm{H}-2-37381)$

RISER NUMBER (8)

RISER ELEVATION (Ft.) 666.9100

TANK CL BOTTOM ELEV. (FE.) - 628.0000

RISER TO TANK BOTTOM ELEV. \{FE.\} $\begin{array}{r}38.9100 \\ 466.92\end{array}$

DETERMINING REFERENCE LEVEL:

$1 / 16$ GASKET @ 50\% COMPRESSION (In.) + 0.0313 (B)

PVC FLANGE (OPTIONAL) (In.) + 1.0000 (C)

$1 / 8$ GASKET @ 50\% COMPRESSION (In.) + 0.0625 (D)

BALL VALVE FLANGE TO FLANGE (In.) + 9.0000 (E)

BALI INSET DIM (FROM TOP) (In.) - 1.2100 (F)

IMMERSION DEPTH AT 1.05 Sp. G. (In.) + 0.2775 (G)

REFERENCE LEVEL (IN.) 476.0812

A $+\mathrm{B}+\mathrm{C}+\mathrm{D}+\mathrm{E}+\mathrm{F}$ Ft: $\dot{\mathrm{G}}\} \quad 39.6734$

\section{¿IMMERSION DEPTH CALCULATION}

GOVERNING EQUATION

$\mathrm{H}=\left(4^{\star} \mathrm{Fb}\right) /\left(\mathrm{Sg}^{\star} \mathrm{P} i \star \mathrm{D}^{\star *} 2\right)$

$\mathrm{Fb}=$ BOUYANT FORCE $=$ SET POINT $=15.0000$ GRAMS

$\mathrm{Sg}=$ SPECIFIC GRAVITY OF LIQUID $=1.0500$

$\mathrm{D}=$ DISPLACER DIAMETER $=2.0000$ INCHES

$\mathrm{H}=$ IMMERSION DEPTH (FROM EQUATION) $=0.7048$ CENTIMETERS 


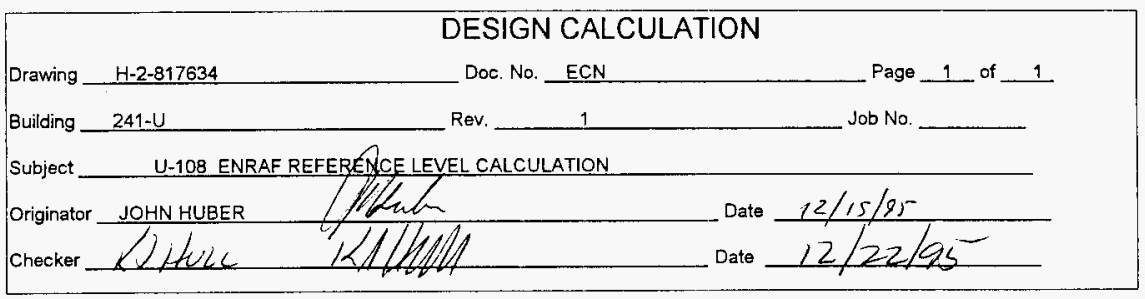

TANK NUMBER U-108

BOTTOM OF TANK TO RISER DIMENSION

DRAWING NUMBER (H-2-37381)

RISER NUMBER

(8)

RISER ELEVATION (Ft.) 665.9500

TANK CL BOTTOM ELEV. (Ft.) - 627.0000

RISER TO TANK BOTTOM ELEV. \{ Fr. $\begin{aligned} & 38.9500 \\ & 467.4\end{aligned}$

DETERMINING RERERENCE LEVEL:

$1 / 16$ GASKET @ 50\% COMPRESSION (In.) + 0.0313 (B)

PVC FLANGE (OPTIONAL) (In.) + 1.0000 (C)

$1 / 8$ GASKET @ 50\% COMPRESSION (In.) + 0.0625 (D)

BALL VALVE FLANGE TO FLANGE (In.) + 9.0000 (E)

BALL INSET DIM (FROM TOP) (In.) - 1.4700 (F)

IMMERSION DEPTH AT $1.05 \mathrm{Sp}$. G. (In.) +0.2775 (G)

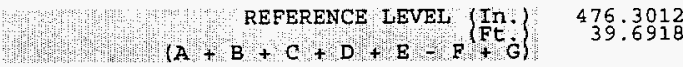

- IMMERSION DEPTH CALCULATION

GOVERNING EOUATION

$H=(4 * \mathrm{Fb}) /\left(S g * P i \star D^{\star} \star 2\right)$

$\mathrm{Fb}=$ BOUYANT FORCE $=$ SET POINT $=$

15.0000 GRAMS

Sg = SPECIFIC GRAVITY OF LIQUID =

1.0500

$D=$ DISPLACER DIAMETER $=$

2.0000 INCHES

$H=$ IMMERSION DEPTH (FROM EQUATION) =

0.7048 CENTIMETERS
} 


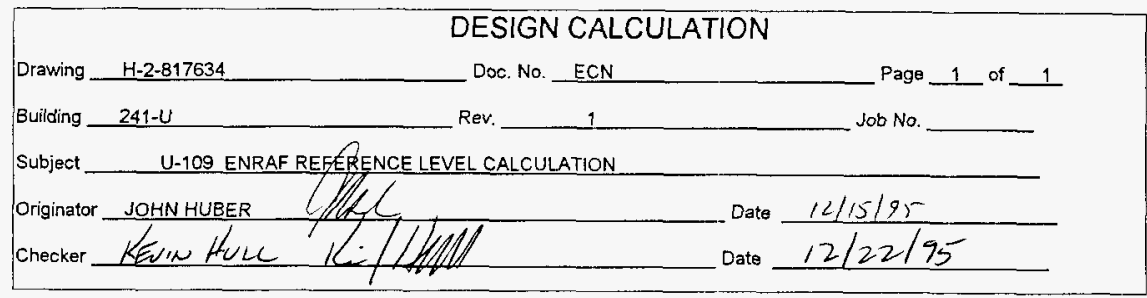

TANK NUMBER

BOTTOM OF TANK TO RISER DIMENSION

DRAWING NUMBER

RISER NUMMBER

RISER ELEVATION (FE.)

TANK CL BOTTOM ELEV. (FE.) - 626.0000

RISER TO TANK BOTTOM ELEV. \{Ft.\} $\begin{array}{r}38.9700 \\ 467.64\end{array}$

DETERMINING REFERENCE LEVEL:

PVC FLANGE (OPTIONAL) (In.) +1.0000 (C)

1/8 GASKET@50\% COMPRESSION (In.) + 0.0625 (D)

BALL VALVE FLANGE TO FLANGE (In.) + 9.0000 (E)

BALL INSET DIM (FROM TOP) (In.) - 1.2100 (F)

IMMERSION DEPTH AT $1.05 \mathrm{Sp}$. G. (In.) + 0.2775 (G)

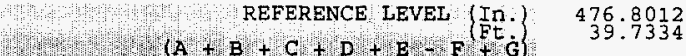

\section{* IMMERSION DEPTH CALCULATION}

GOVERNING EOUATION

$\mathrm{H}=\left(4^{\star} \mathrm{Fb}\right) /\left(\mathrm{Sg}^{\star} \mathrm{Pi} \mathrm{D}^{\star} \mathrm{D}^{\star} 2\right)$

$\mathrm{Fb}=$ BOUYANT FORCE $=$ SET POINT $=15.0000$ GRAMS

$S g=S P E C I F I C$ GRAVITY OF LIQUID =

$\mathrm{D}=$ DISPLACER DIAMETER =

$\mathrm{H}=$ IMMERSION DEPTH (FROM EQUATION) =
1.0500

2.0000 INCHES

0.7048 CENTIMETERS 


\begin{tabular}{|c|c|c|}
\hline & DESIGN CALCULATION & \\
\hline Drawing _H-2-817634 & 626467 & Page 1 of 1 \\
\hline Building $\quad 241-U$ & Rev. $\quad 0$ & Job No. $2 \omega .95-829$ \\
\hline U-110 ENRAF REFERENCE LE & EL CALCULATION & \\
\hline Originator JOHN HUBER T/tes & Date & $10 / 24 / 95$ \\
\hline Checker Nasser Razfar pertelecon & the & $11 / 6 / 85$ \\
\hline
\end{tabular}

BOTTOM OF TANK TO RISER DIMENSION

DRAWING NUMBER (H-2-37381)

RISER NUMBER (8)

RISER ELEVATION (Ft.) 666.9200

TANK CL BOTTOM ELEVATION (Ft.) - 628,0000

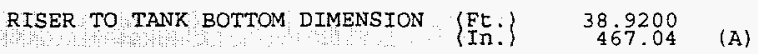

DETERMINING REFERENCE LEVEL:

$1 / 16$ GASKET @ 50\% COMPRESSION (In.) + 0.0313 (B)

PVC FLANGE (OPTIONAL) (In.) +1.0000 (C)

$1 / 8$ GASKET @ 50\% COMPRESSION (In.) + 0.0625 (D)

BALL VALVE FLANGE TO FLANGE (In.) + 9.0000 (E)

BALL INSET DIM (FROM TOR) (In.) - 1.4700 (F) FIELDMEASURED FROMH-

IMMERSION DEPTH IN SOLIDS (In.) + 0.0000 (G)

REFERENCE TEVEL \{ In: $\} 475.6637$

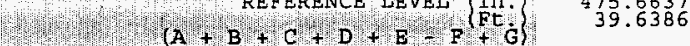




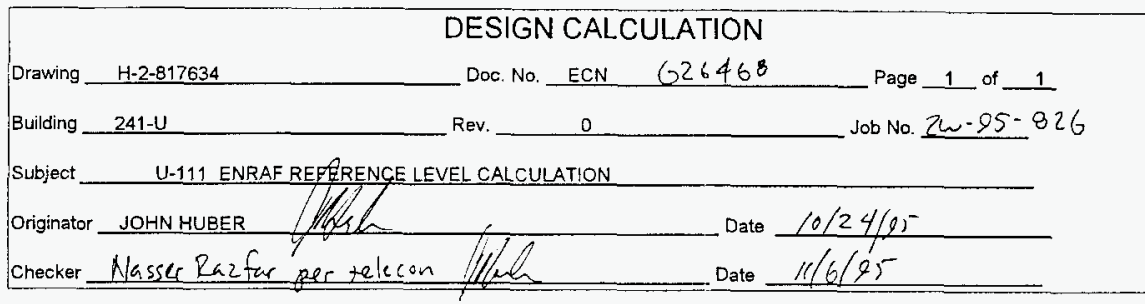

\section{BOTTOM OF TANK TO RISER DIMENSION}

DRAWING NUMBER

$(\mathrm{H}-2-37381)$

RISER NUMBER

$$
\text { RISER ELEVATION (Ft.) } 665.9900
$$

TANK CL BOTTOM ELEVATION (Ft.) - 627.0000

RISER TO TANK BOTTOM DIMENSION $\left\{\begin{array}{l}\text { FE. } \\ \text { In. }\}\end{array} \begin{array}{r}38.9900 \\ 467.88\end{array}\right.$

\section{DETERMINING REFERENCE LEVEL:}

$1 / 16$ GASKET @ 50\% COMPRESSION (In.) + 0.0313 (B)

PVC FLANGE (OPTIONAL) (In.) +1.0000 (C)

$1 / 8$ GASKET @ 50\% COMPRESSION (In.) + 0.0625 (D)

BAIL VALVE FIANGE TO FLANGE (In.) + 9.0000 (E)

BALL INSET DIM (FROM TOP) (In.) - 1.4700 (F)

IMMERSION DEPTH IN SOLIDS (In,) +

$0.0000 \quad(G)$

FIELD MEASURED FROM H-

REFERENCE LEVEL (In; $\quad 476.5038$

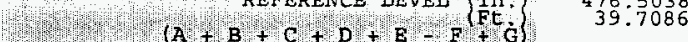


WHC-SD-WM-CN-078 REVISION 0

THIS PAGE RESERVED FOR U-112 
WHC-SD-WM-CN-078

REVISION 0

THIS PAGE RESERVED FOR U-201 
THIS PAGE RESERVED FOR U-202 


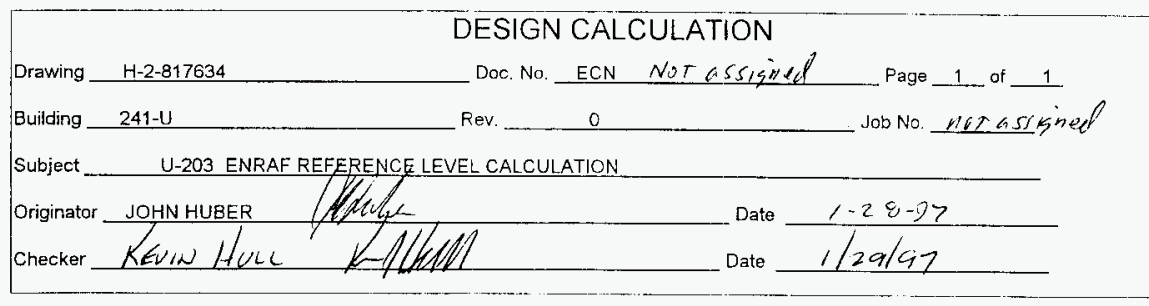

TANK NUMBER U-203

BOTTOM OF TANK TO RISER DIMENSION

DRAWING NUMBER (H-2-1742)

RISER NUMBER (1)

RISER ELEVATION (Ft.) $\quad 664.9300$

TANK CL BOTTOM ELEVATION (Ft.) 626.5000

RISER TO TANK BOTTOM DIMENSION (Ft) $\quad 38.4300$

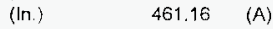

DETERMINING REFERENCE LEVEL:

$0.0313 \quad(B)$

PVC FLANGE (OPTIONAL) (In.) + 0.0000 (C)

1/8 GASKET@ $90 \%$ COMPRESSION $($ In. $)+\quad 0.0000$ (D)

BALL VALVE FLANGE TO FLANGE (In.) + 9.0000 (E)

BALL INSET DIM (FROM TOP) (In.) - $\quad 1.4700 \quad$ (F)

IMMERSION DEPTH IN SOLIDS (ln.) + $0.0000 \quad$ (G)

FIELD MEASURED FROM $\bar{H}$ -

2.817634 P/N 48

REFERENCE LEVEL (In.) $\quad 468.7213$

(Ft.) $\quad 39.0601$

$(A+B+C+D+E-F+G)$ 


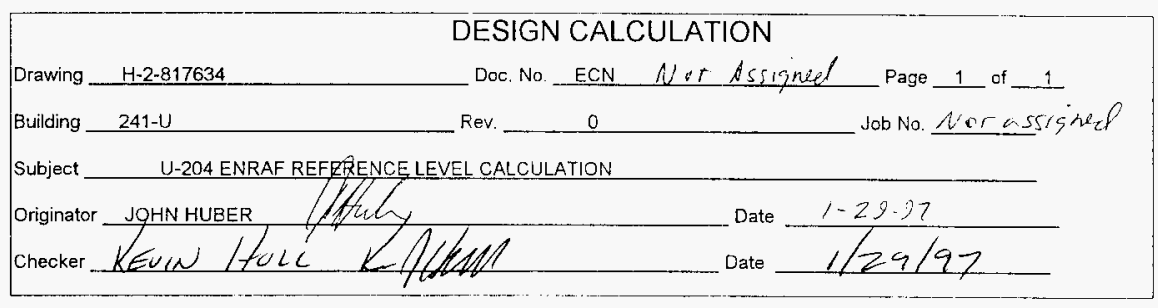

TANK NUMBER

U-204

BOTTOM OF TANK TO RISER DIMENSION

DRAWING NUMBER

(H-2-1742)

RISER NUMBER

(1)

RISER ELEVATION (Ft)

664.9700

TANK CL BOTTOM ELEVATION (Ft) 626.5000

RISER TO TANK BOTTOM DIMENSION (Ft.)

(In.)

38.4700

$461.64 \quad$ (A)

DETERMINING REFERENCE LEVEL:

1/16 GASKET @ 50\% COMPRESSION (In.) +

$0.0313 \quad$ (B)

PVC FLANGE (OPTIONAL) $(\mathrm{n})+\quad 0.0000$

1/8 GASKET @ 50\% COMPRESSION (In.) +

$0.0000 \quad$ (D)

BALL VALVE FLANGE TO FLANGE (In) +

9.0000

(E)

BALL INSET DIM (FROM TOP) (In.) -

$1.4700 \quad(F)$

IMMERSION DEPTH IN LIQUID (In.) +

0.2775

(G)

FIELD MEASURED FROM H2-817634 PIN 48

REFERENCE LEVEL (n.)

(Ft)

$(A+B+C+D+E-F+G)$

469.4788

39.1232

\section{*IMMERSION DEPTH CALCULATION}

GOVERNING EQUATION

$H=\left(4^{\star} \mathrm{Fb}\right) /\left(\mathrm{Sg}^{\star} \mathrm{Pi}^{*} \mathrm{D}^{\star \star} 2\right)$

$\mathrm{Fb}=$ BOUYANT FORCE $=$ SET POINT $=$

15.0000 GRAMS

$\mathrm{Sg}=$ SPECIFIC GRAVITY OF LIQUID =

1.0500

$D=$ DISPLACER DIAMETER =

$5.0800 \mathrm{CM} \quad$ (2.00 INCHES)

$H=$ IMMERSION DEPTH (FROM EQUATION) =

0.7048 CENTIMETERS

$0.2775 \quad \mathrm{NCH}$ 


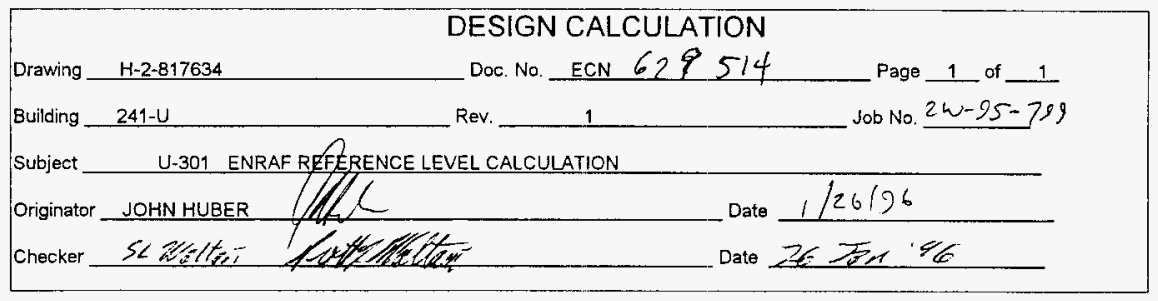

TANK NUMBER U-301

BOTTOM OE TANK TO RISER DIMENSION

DRAWING NUMBER (H-2-1749)

RISER NUMBER (1)

RISER ELEVATION (Ft.) 664.9500

TANK CL BOTTOM ELEVATION (Ft.) - 634.1300

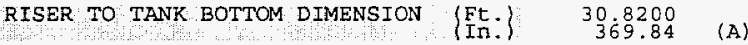

DETERMINING REFERENCE LEVEL:

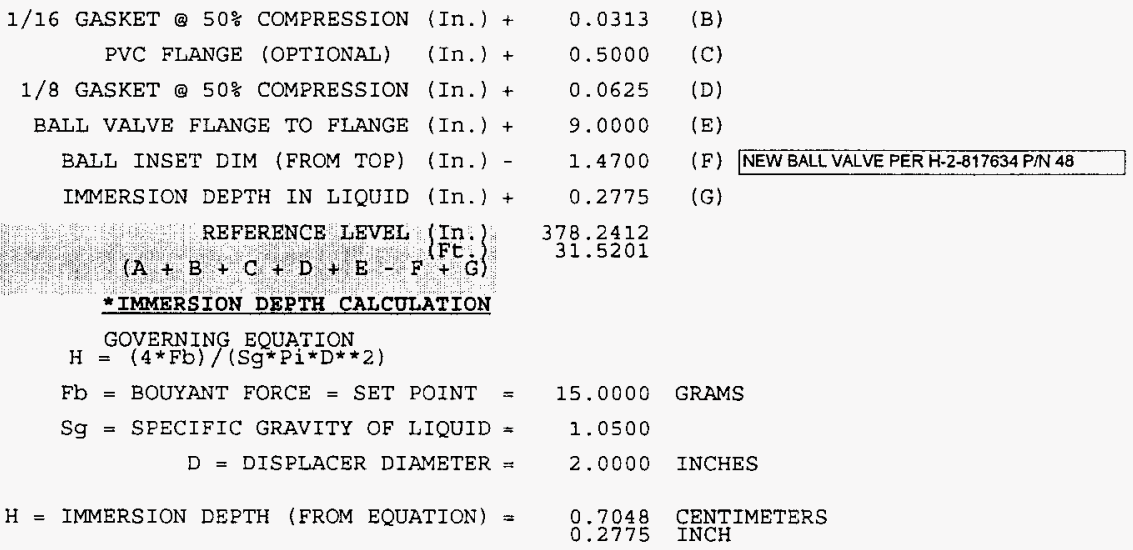




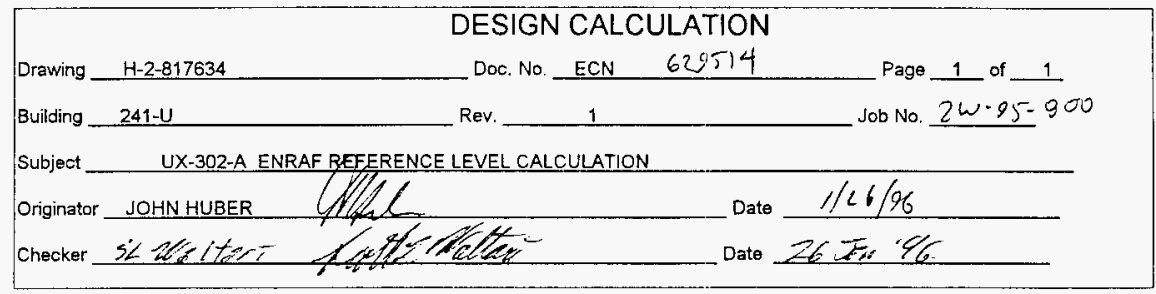

TANK NUMBER UX-302-A

BOTTOM OF TANK TO RISER DIMENSION

DRAWING NUMBER ( $\mathrm{H}-2-832)$

RISER NUMEER (N/A)

RISER ELEVATION (Ft.) 712.1800

TANK CL BOTTOM ELEVATION (Ft.) - 682.5000

RISER TO TANK BOTTOM DIMENSION : (FE.): $\begin{aligned} & 29.6800 \\ & 356.16\end{aligned}$

DETERMINING REFERENCE LEVEL:

$1 / 16$ GASKET Q $50 \%$ COMPRESSION (In.) + PVC FLANGE (PRTIONAL) (In.) +

$1 / 8$ GASKET @ 50\% COMPRESSION (In.) + BALL VALVE FLANGE Id FLANGE (In.) + BALL INSET DIM (FROM TOP) (In.) IMMERSION DEPTH IN LIQUID (In.) + REEERENCE LEVEL (In . $(\mathrm{A}+\mathrm{B}+\mathrm{C}+\mathrm{D}+\mathrm{B}-\mathrm{F}+\mathrm{FE})$

\section{* IMMERSION DEPTH CALCULATION}

GOVERNING EOUATION

$\mathrm{H}=(4 \star F b) /(S g * P i \star D * \star 2)$

$\mathrm{Fb}=$ BOUYANT FORCE $=$ SET POINT $=$ $S g=$ SPECIFIC GRAVITY OF LIQUID = $D=$ DISPLACER DIAMETER = $\mathrm{H}=$ IMMERSION DEPTH (FROM EQUATION) =
0.0313

(B)

0.5000

0.0625

9. 0000

1.4700

(F) NEW BALL VALVE PER H-2-817634 PIN 48

0.2775 (G)

$364 \cdot 5612$

15.0000 GRAMS

1.0500

2.0000 INCHES

$\begin{array}{ll}0.7048 & \text { CENTIMETERS } \\ 0.2775 & \text { INCH }\end{array}$ 